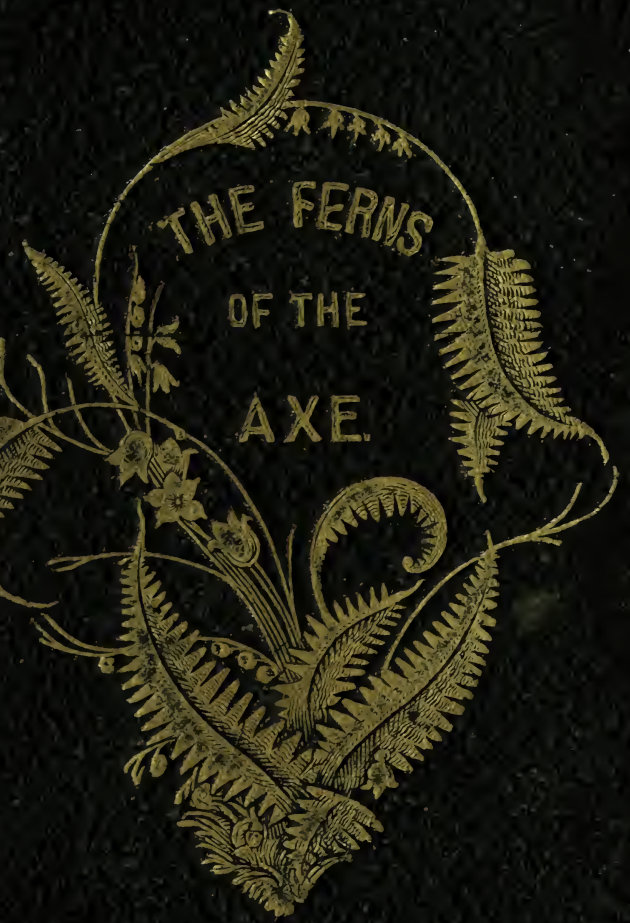


23 nom 1902

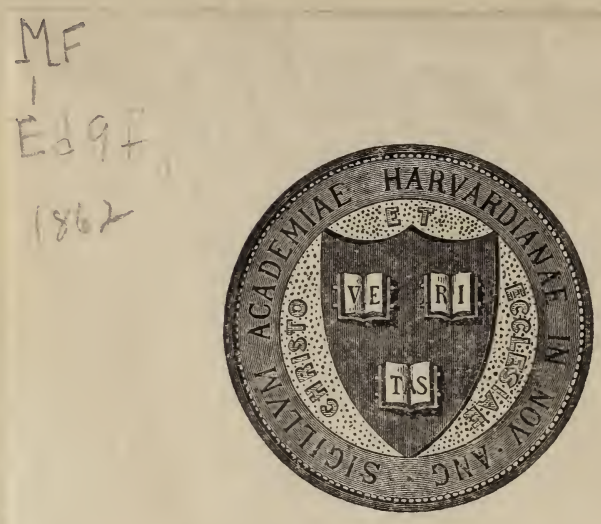

HARVARD UNIVERSITY

LI B RA R Y

OF THE

GRAY HERBARIUM

Received Apr. 10,1936

Bought

Weldon \& Wesley, Ltd.

Natural History Booksellers

2-4 Arthur St. London W.C.2 
<smiles>[C]1CCC1</smiles> 




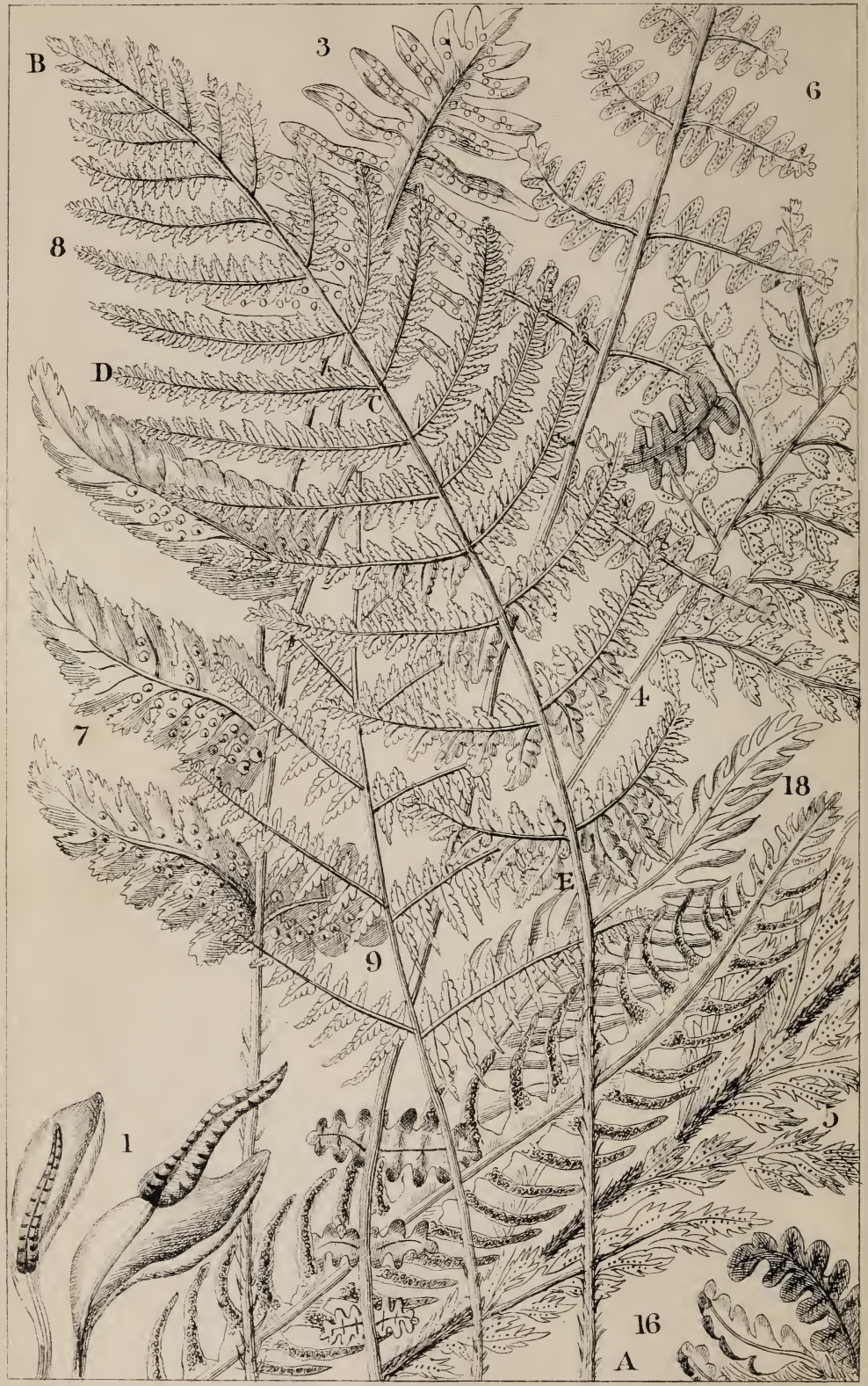


THE

\section{FERNS OF THE AXE}

AND

\section{ITS TRIBUTARIES;}

ALSO OF

LYME, CHARMOUTH, UPLYME, AND MONKTON WYLD, WITI AN ACCOUNT OF THE FLOWER

\section{LOBEIIA URENS,}

FOUND WILD NEAR AXMINSTER, AND NOWHERE ELSE IN GREAT BRITAIN.

BY

THE REV. Z. I. EDWARDS, M.A.,

RECTOR OF COMBPYNE, AND LATE FELLOW OF WADIIAM COLLEGE, OXFORD.

IIエUSTRATED.

LONDON :

HAMILTON, ADAMS, AND CO., 33, PATERYOSTER ROW. CHARD : THOMAS YOUNG.

1862 . 



\section{P REFACE.}

The intention of this little work, is not to supply the public with any new information on the subject of Ferns, but rather to present in an intelligible and interesting form, what has been gathered from personal observation, and other sources, respecting these beautiful plants of the neighbourhood. Some may recognise a portion of what is written as having already appeared in a local newspaper. An endeavour is now made to express the matter more fully. The most simple language is used, with a view that not merely the scientific, but those who are in any way observant, may easily discover and admire some of nature's productions on our walls, woods, and hedge-banks. To make it locally interesting, the places are named where the rarer Ferns are found. Not every spot is mentioned, neither is it attempted to describe all the varieties. Sufficient, it is hoped, is said, to give an impetus for making fresh discoveries.

The author cannot refrain from giving his best thanks to the many kind friends who have helped him in procuring illustrations and specimens, and in various other ways; wherever he has visited, he has met with a kindly feeling and a friendly reception; whether strangers or acquaintances, rich or poor, all have endeavoured to facilitate his labours, and he sincerely hopes that they will be amused, if not instructed, by the volume now presented to their notice. 


\section{CORRIGENDA.}

Page 8, for Ophioglossam read Ophioglossa.
" "Botrychiam
" Botrychia
"9, \# Heart's-tongue
"10, " Athyriam
" Hart's-tongue
$" \quad$ "Aspleniam
"12, " Botrychiam
"49," Officinalis
"60," chaunted
"69, " Polystichium
"96, " Page 60
" Athyria
"Asplenia
" Botrychia
" Officinarum
" chanted
" Polystichum
" Page 68 


\section{THE REGION OF THE AXE.}

IT was our original intention to have confined our researches to "The Ferns of the Axe,"-the Ferns of the parishes, through which the Axe and its tributaries flow-but the romantic dells of Uplyme, the bold hills overhanging Lyme, Charmouth, with the distant view of the majestic Goldencap, and the wild scenery around Monkton Wylde, cannot be passed over by the lover of nature's works. The plants are so choice and the neighbourhood so inviting, that though our stream will not water these spots, we must consider Lyme, Charmouth, Uplyme, and Monkton Wylde, as belonging to the region of the Axe. Neither are the various parishes, through which our river and its branches and streamlets flow, devoid of great beauty. The fine open bay of Seaton, with Haven cliff on the one side and the perpendicular white chalk rocks of Beer on the other, are points of great attraction. As we advance onward, the view of Colyton Church, with its noble tower raising its head in a lovely vale, arrest the eye and charm the beholder. As the stream winds its bending course further still, the rich, luxuriant meadows near Axminster, with the prospect of Cloakham house, and the Dalwood and Stockland hills, seem to tell the traveller a tale, that he is treading on enchanted ground. 'I'wo miles to the east is Trinity hill, whence we behold the clear blue waters of the sea, the river gliding through the vale, a diversified prospect of hills and dales with a distant and sometimes clear view of Heytor in the forest of Dartmoor. As we reach nearer the source of the Axe, we pass by Forde Abbey, known for its splendid tapestry and pleasant and agreeable situation. Wending our course onward, we have on the right bank the parish of Crewkerne, a parish to be admired for its noble Church 
nestling among the trees, however much we may regret that it is not so favourable for promoting the growth of our favourite plants. At the very source itself we enter the parish of Beaminster, lying in the midst of beauteous eminences and sloping hills, adorned with flowers and Ferns and many a rural treasure. On the tributaries we have Cricket House, the seat of Lord Bridport, with its wellwooded and undulating grounds, the ancient town of Chard, said to have been built by Cerdic, king of the West Saxons, and the pleasant retreats of Farway, Offwell, and sundry other pretty villages. On every side, all is deeply interesting. From the village and bounds of Charmouth to the utmost point of Stockland hill; from the beach of the little fishing village of Beer to Axe Knoller, the source of the stream; whether we turn to the right hand or to the left, our eyes are continually feasted with the loveliest scenery. The wood, the hills, the vales diversify the prospect and pour forth in richest profusion the choicest productions of a gracious God.

\section{THE FERNS OF THE AXE.}

Ferns generally delight in a moist and humid clime. Though few of ours grow by the river's side, yet the same liquid element that feeds the water of the one, gives life to the other. There is scarcely a bog or dripping wood or damp shady lane, where traces of the Fern tribe are not to be found throughout this interesting neighbourhood. In many a neglected wall, or bridge, or Church, or crevice of a rock, the humbler of these plants are seen creeping with their rolled-in buds, and silently demand our praise and observation. Nay, the very works of art cannot expel these dear children of nature. As certain of the feathered tribe have left their natural haunts, and thronged to the habitations of men, so certain of these Ferns have deserted their original residence among the rocks, and are scarcely ever seen except upon buildings and walls, the artificial work of man. The river Axe and its tributaries pass through three Counties and thirty-nine parishes. Respecting these we shall endeavour to point out the habitats of the rarer plants. Stiff clay 
soils and dry situations are generally unfavourable and uncongenial: their favourite resort is in abundant moisture and shade. The Fern Trees of the Tropics are found in dense and wet woods. Our most luxuriant specimens are where the sun does not scorch, and the ground is saturated with moisture, and the air is damp and misty. If Ferns exist at all in dry regions, they are so stunted and changed, that they could hardly be supposed to be identical with those that appear so rich and luxuriant. Brake and Moonwort are an exception to this rule. The former, however, is far more stately and exalted in the dense and shaded wood, than in the open down.

The parishes are-In Devonshire-Axminster, Axmouth, Colyton, Combpyne, Cotleigh, Dalwood, Farway, Kilmington, Membury, Musbury, Northleigh, Offirell, Stockland, Southleigh, Seaton and Beer, Uplyme, Shute, Widworthy, Yarcombe. In Dorset-Beaminster, Broadwinsor, Burstock, Chardstock, Charmouth, Cheddington, Hawkchurch, Lyme, Monkton Wylde, Mosterton, Wambrook. In SomersetBuckland St. Mary, Chard, Combe, Crewkerne, Otterford, Seaborough, Wayford, Whitestaunton, Winsham.

\section{HISTORY OF FERNS.}

"Non tamen ista filix ullo mansuescit aratro."-Pers. Sat. 4, v 41. That fern however is not improved by any plough.

Theopirastus, a Greek philosopher of the third century before Christ, praises their medicinal properties, and Dioscorides, a physician who flourished in the reign of Nero, and whose works were referred to as the fountain-head of all authority on the subject of botany and the virtues of plants for sixteen centuries, speaks of the Male Fern or Brake, (pteris) the Female Fern, (thelypteris) probably the Common Polypody, (dryopteris) and several others. Both these authors wrote in the Greek language, and many of their works are still extant. The Greeks called Fern pteris on account of its plumose or feathery appearance. Theocritus, the pastoral poet, also has this allusion.

"But if you too come, you shall walk here on tender fern."Idyll 5, v. 55. 
The Romans, too, were acquainted with fern. The Latin name is said to be derived from (filum) a thread, because many species are cut and divided most elegantly into threadlike portions. Three leading Roman poets* are loud in their inrectives against one particular species, because its underground creeping stem is troublesome.

"Et filicem curvis invisam pascit aratris."-Vir. Georg. 1. 2. v. 189.

The soil feeds the fern hateful to crooked ploughs.

An expression however, in Cicero, the great Roman orator, (patera filicatce,) "bowls adorned with fern leaves" shows that the ancients, like ourselves, considered these plants to be highly ornamental. In our own country, the earliest writer of any celebrity, who speaks of the properties and species of Ferns, is Gerarde, the Herbalist. He lived in the reign of Queen Elizabeth, and enjoyed the patronage and support of Lord Burghley. In his work there are some curious and striking remarks on the virtues of these plants. Parkinson, who lived in the unfortunate reign of Charles the first, took a more enlarged view of natural history, gave a fuller description of plants, and did not confine himself to their medical uses and properties: He severely criticized the ridiculous stories about Ferns. Of moonwort he says "Some Alchymists also in former times have wonderfull extolled it to condensate or convert quicksilver into pure silver, but all these tales were but the breath of idle-headed persons, which divers to their cost and losse of time have found true, and now are vanished away with them like the air or smoke therein." The greatest and most distinguished of our countrymen, who turned his attention to this subject and to plants generally, is Ray. He was the son of a blacksmith at Black Notley, near Braintree, in Essex. He was educated at Cambridge, where he greatly distinguished himself. He first brought into notice that which is called the natural system in the regetable kingdom, and gave the classical name to many of our English Ferns. He lived in the reign of Charles the second, and was a Nonconformist. At the present day Moore, Hooker, and Newman take the lead.

* Virgil, Horace, and Persius. 


\section{DESCRIPTION OF A FERN.}

A FERN is the highest order of not-flowering plants, and has fibrous vascular tissue. The leaf or leafy part is called a frond. Plate I. B to E. What is below the frond, is the stalk (stipes) Plate I. $\mathrm{E}$ to $\mathrm{A}$. It has fibrous roots, a creeping underground-stem (rhizome) or an upright trunk or stem

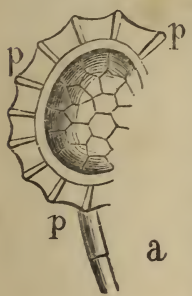

(caudex.) The stalk and sometimes the midrib or mid-stem (rachis) of the frond is for the most part covered with scales. Vide Plate I, fig. E to A. Though a Fern has no flower, it has clusters of spores (seeds) in thin bags invisible to the human eye. In most cases these bags have a jointed elastic ring usually incomplete, which bursts open when the spores are ripe, and allows them to escape. In the representation here given the part $p p p$ is the elastic ring, and the rest of the figure the spore bag. This, too, cannot be seen without a microscope. Most species have the fruit on the back of the leaves, and have their buds rolled in (circinate) before the fronds are expanded. Small as the bags are, and unperceived by the human eye, the spores or seeds contained within them are still more minute.

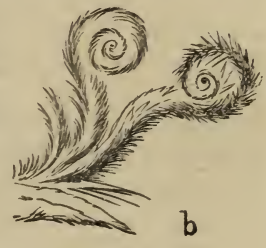

"The seeds of fern which by prolific heat, Cheered and unfolded form a plant so great, Are less a thousand times than what the eye

Can unassisted by the tube descry."-Blakemore.

The organs of reproduction are generally called spores, because proper seeds have an embryo root and one or two leaves, according as it is an Endogen or Exogen. If the seed be sown, as, for instance, the bean, with the embryo root upward and embryo leares downward, the seed will turn itself round and force the leaves upward and the root downwards. Not so the spores. Fern seed was said by the superstitious of yore to render persons invisible, if gathered on the eve of St. John's day.

"We steal as in a castle cocksure,

We have the receipt of fern seed, 
We walk invisible.

Nay, by my faith, I think you are more beholden

To the night than to fern seed for your walking invisible." Shakspeare, Henry 4, Act 2, Scene 1.

There is also a great difference between the veins on the leaflets of Ferns and those on the leaves of the great orders of flowering plants. There generally is a mid-vein, from which issue veins on either side, that are either undivided or divide into two, three, or four lines, with the fructification on one or more of these. Many of the Ferns found in the coal formations are named according to the division and direction of the veins. The fronds are rarely undivided, as the Hartstongue. Plate II, fig. 17. What, indeed, constitutes the chief beauty and elegance of this part of the vegetable world, is the peculiarly chaste and striking manner in which the various parts of a frond are cut and severed. Not the finest tool of the most skilful mechanic could perform such exquisite workmanship. No rich colour, as in the rose and camelia, no sweet perfume, as in the violet: it is the matchless distribution of the various parts, that is so attractive and ornamental. Some Ferns have the fronds deeply divided, but not to the mid-rib or rachis as the common Polypody, Plate I, fig. 3. Others are divided to the rachis and have distinct leaflets on each side, as the Maidenhair Spleenwort, Plate II, fig. 12. These are said to be pinnate and the frond is called a pinna. If on either side of the rachis, we have many pinnæ, as Plate II, fig. 11, the Fern is said to be bipinnate; and, if instead of mere leaflets on such a pinna, there are some little pinnæ or branchlets, as Plate I, fig. 8 , * then it is said to be tripinnate. If as in Plate I, fig. 6 , the branches are deeply divided, but not to the mid-rib, then the frond is said to be nearly bipinnate. The elegance is also increased by little incisions or cuts on the edges of the leaflets, some resembling those of a saw (serrate), some bluntly notched, and others more rounded. A few have little bristles here and there, as in the Prickly Fern, Plate I, fig. 4. The shape of the leaflet should be attended to, as this gives a character to the plant. They are either eggshaped, as the Adder's-tongue, or lance-shaped, as in the Black-stalked Spleenwort, or oblong as the Mountain Fern,

* Particularly notice the lowest pinnæ. 
Plate I, fig. 6, or nearly round, as the Maidenhair Spleenwort, Plate II, fig. 12, or diamond-shaped, as the Wall Rue Spleenwort, Plate II, fig. 14, or strap-shaped, as the Hart'stongue generally is. Sometimes they have a little lobe or projection sticking out on one side, as the Prickly Fern, Plate I, fig. 4. There is one more distinctive mark to be noticed, and that is the form of the entire frond. We should notice whether it be triangular, lance-shaped, linear, (i.e. like a line) \&c. Most of our Ferns are mere herbs, scarcely any can be called bushes. The highest are rarely ten feet. Tree Ferns are found in the Tropics and South Temperate Zone, while in the North Temperate and Frigid they are only herbaceous. Their geographical distribution varies. In islands it is great. In Jamaica 1 to 9, Iceland 1 to 18, Scotland 1 to 31 . On the Continent it is less. In France 1 to 63, Portugal 1 to 116, Egypt 1 to 971.

\section{CLASSIFICATION.-Help to the Discovery of Ferns.}

IF we discover a plant which has its buds rolled in or coiled together, and with dusty rust-red fruit, ${ }^{*}$ it is most probably a Fern. When we wish to search it out, we must particularly observe where the fructification lies. If the clusters of fruit are on a spike separate from, but attached to the leaf or frond, it is one of the Tongueworts (Ophioglossacece.) If the clusters are in a large panicle at the ends of the fronds or of portions of the fronds, it is one of the Osmunds (Osmundacece.) If on the back of the leaflets of a frond with or without a cover, it is one of the Polypods (Polypodiacea.) Thus we discover the three Sub-orders or tribes of Ferns.

I. Tongueworts. Ophioglossacea. Clusters on a spike separate from, but attached to the frond. There is no elastic ring to the not-transparent bags of spores, neither are the buds of the plants rolled in (circinate.)

II. Osmunds. Osmundacea. Clusters at the ends of the fronds or of portions of the frond. Bags of spores have frequently a lid-like ring. Buds rolled in.

\footnotetext{
* In old plants it is sometimes black.
} 
III. Polypods. Polypodiacea. Clusters on the back of the frond* with or without a cover. Bags of spores with a jointed elastic ring. Buds rolled in.

We will next proceed to consider the genus and species of each Sub-order. If we meet with a plant having a leaf and a spike undivided, and growing in wet clay or loamy fields, it is most probably an Adder's-tongue, Ophioglossum, but if we meet with one having a pinnatifid leaf and a clustered spike on a dry sandy or peaty soil, we should inspect it and see whether it be the Moonwort, Botrychium. Thus we determine the genera of the first Sub-order.

\section{TONGUEWORTS. Ophioglossacea.}

1. Adder's-tongues. Ophioglossan Clusters of fruit on a two-rowed spike attached to an undivided frond.

2. Clustered Tongueworts. Botrychialt. Fructification on a clustered spike with a deeply divided frond.

If we observe a Fern-like plant with the rust-red fruit growing at the ends of the fronds, and not on the back of the leaflets, and without an elastic ring to the bags of spores, we may take it for granted that this is an Osmunda, the only British genus of the Second Sub-order. Hence we proceed.

\section{OSMUNDS. Osmundacec.}

Osmunda. Fruit growing on a clustered branch at the end of a frond. Bags of spores without an elastic ring.

We now come to the Third Sub-order, which takes in all the other British, and by far the greater part of the Ferns found in the whole world, from the Tropics to the Arctic and Antarctic regions. They vary exceedingly from the largest tree ferns to the smallest species scarcely perceptible to the eye. To facilitate the discovery of these plants, our British Polypods are divided into four families. In most species the clusters of fruit have a thin white or very light

\footnotetext{
* Some genera have the clusters on a columnar receptacle arising from their side veins. These not found here.
} 
green cover (indusium.) The first family have no covers and are called Polypodies. Polypodiea. The second have a roundish cover* and are designated Shieldworts. Aspidiece. The third have a linear one, as appears in the Heart'stongue, Plate II. fig. 17, not parallel to the mid-rib, and bear the name of Spleens. Aspleniea. The fourth have a linear cover, either parallel to the edge of the leaflet, or formed by that edge bent back and rolled in. These are Maidenworts. Adiantece. Thus we have

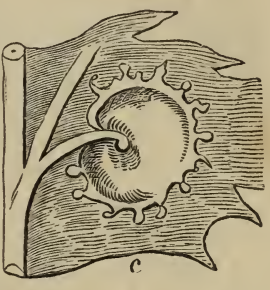
four families of Polypods. The names of these, and their distinctive marks, and their respective genera, are

POLYPODS. POLYPODIACEÆ.

Familu I.

I. Polmpodies. Polypodiece. Corers none. Clusters seated on the back of the side-veins.

\section{Genus.}

Polypody. Polypodium. Clusters round on the middle of the underside of the lobes or leaflets of the frond.

\section{FaMILY II.}

II. Shieldwonts. Aspidiece. Clusters round. Covers roundish not attached by the outer edge.

2 Genera.

1. Shield Ferns. Lastrea. Covers roundish or kidneyshaped, having a slit in it, and attached by the inmost point of that slit to the back of the side-vein. Veins distinct and separate after leaving the mid-rib. The best type of this genus is the Male Fern. The cover of etching $\mathrm{c}$. is that of this genus.

2. Prickly Ferns. Covers round, attached by the centre. The bristles on the edges of the leaflets are a leading character of this genus.

FAMILI III.

III. Spleens. Aspleniece. Clusters of fruit linear or oblong, or rarely roundish. $\uparrow$ Covers linear, $\ddagger$ but not parallel

* This etching is magnified, as the covers in Plate I, fig. 7 are rather less than the natural size.

+ In one variety of Lady. Fern this is the case. $\ddagger$ Not always a straight but sometimes a curred line. 
to the edge of the leaflet, placed on the sides of the veins.

\section{Genera.}

1. Lady Ferns. Athyrian. Clusters oblong, kidneyshaped. Covers crescent-shaped, opening towards the midrib of the leaflets. The detached edge fringed. The clusters and covers of this genus greatly vary, sometimes they appear - nearly round, at other times almost a straight line. The covers are almost always more or less crescent-shaped.

2. Spleenworts. Aspleniah. Clusters linear, straight. Covers extended in a long straight line, and opening towards the mid-rib. The plants of this genus have generally a stiff form and a polished stalk.

3. Scaly Spleenworts. Ceterach. Clusters linear, straight. Covers narrow, upright on each branch of side-veins. Sideveins unite and form a net work. Back of leaflets enveloped in chaffy scales.

4. Hart's-tongue. Scolopendrium. Clusters and covers in pairs, one seated on the upper and the other on the lower branch of each side-vein, and opening to face each other. Plate II, fig. 17.

\section{FaMILY IV.}

IV. MaIdenwonts. Adiantea. Cover linear, either paral. lel to the edge of the leaflets, or formed by their bent-back edges.

\section{Genera.}

1. Hard Ferns. Blechna. Bags of spores lying in a long straight line. Side-veins of fruit-bearing fronds joined by a line somewhat parallel to the mid-rib. The fructification lies between these parallel lines. This is most distinctly seen when the specimen is sparingly fruited.

Brake. Pteris. Bags of spores in a long straight line covered by the bent-back and rolled-in edge of the leaflets. 


\section{I. \\ TONGUE-WORTS. OPHIOGLOSSACEA.}

THese are the least resembling Ferns of the three British Sub-orders. We have placed them first on the list, as being the most natural transition from the flowering plants. In many respects they differ from the others. The rusty fruit is not on the back of the frond, but on a separate spike merely attached to the base. The buds do not roll in. The veins are not even distinct in the Adder's-tongues, but mix one with another, as in a large portion of the flowering plants (the Exogens.) They also do not grow in woods or shady hedge-banks, or walls, or rocks, but are almost always to be found in the open fields or downs. Throughout the world this is a small Sub-order. We have but one species to each genus.

\section{Adder's-tongues. Ophioglossa.}

"For them, that are with newts, or snakes, or adders stung,

He seeking out an herb that's called Adder's-tongue,

As nature it ordained its own like hurt to cure,

And sportive did herself to niceties inure."

$$
\text { Plate I, fig. } 1 .
$$

Adder's-tongue. Ophioglossum vulgatum. The leaf of this plant, for we can hardly call it a frond, is egg-shaped, netveined. It has a pale green colour, from four to ten inches high. The spike on which the fructification lies, issues from the sheathing part of the leaf, and is generally of the same height, sometimes much higher. The fruit bearing part is generally rather shorter than the other part of the spike beneath. When it is ripe, it appears notched on each side, bearing some resemblance to the teeth of a blunt saw. We almost always find it growing in stiff and badly drained clay fields. Cultivation will diminish, but not altogether exterminate it. A friend informs us, that "in some fields to the north of Wootton, a village near Charmouth, the Adder'stongue grows so plentifully, as to give them a peculiar shade." "Seldom does the fruit appear on the spike, through the ruthless hand of the mower, who befriends not the student of nature's works.

Our attention was directed to this plant by a "clever woman," who pronounced it the component part of one of 
the best of ointments. An old man some time since died in Axminster Union House, who, in by-gone days, had, in a great measure, supported himself by itinerating in various parts of Somersetshire for the purpose of vending an ointment of which this is a constituent part. It was pronounced highly beneficial for certain diseases of cattle. When in a dying state, he gave the receipt to another pauper, who seems to have gained a maintenance from a medicine composed of this wonderful herb, as he has discontinued from that time being a constant inmate of the Workhouse. The old poet, whose verses we have quoted, pronounces this a sovereign remedy against Adder's poison. We have yet to learn from the faculty, whether this be an undoubted fact. We know for a certainty that some of our farriers have many fronds and spikes gathered every spring, and use it for a specific in the diseases of cattle, and the poor creatures recover. Whether they would get rid of their ailments without this restorative, we will not presume to determine.

This is no easy plant to cultivate. Care must be taken not to remove the surrounding weeds or to cut the roots, or in any way to expose them. It must be placed in a stiff loam or clay, and be well supplied with moisture.

This Fern is found in great abundance in the months of May and June. At Charmouth, in the fields near the pathway to Wootton; Axminster, in the fields near Evil Lane, Park, Lodge Farm, and Great Wood, also in clay fields near Wyke; Chardstock, in fields near the base of Tytherleigh hill, and also in clay fields near Chard, Combe, and various parts of Axmouth, and in almost every parish throughout the district.

2. Clustered Tongueworts. Botrychian.

"The first light night, when the new moon set,

When all was doffe and mirk,

We saddled our nags with the moon fern leaf, And rode from Kilmenin Kirk."

\section{Plate III.}

Moonwort. Botrychium lunatum. The frond is divided into bluntly notched segments, resembling a fan or a halfmoon. The segments or leaflets have no mid-vein. The veins issue from the base of the leaflets, and frequently 

50,

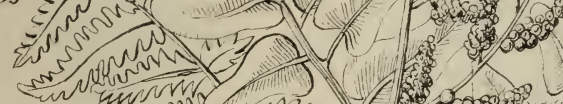

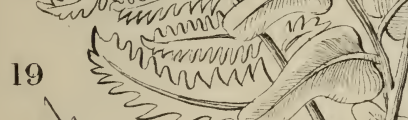

mamminM

W

(5)
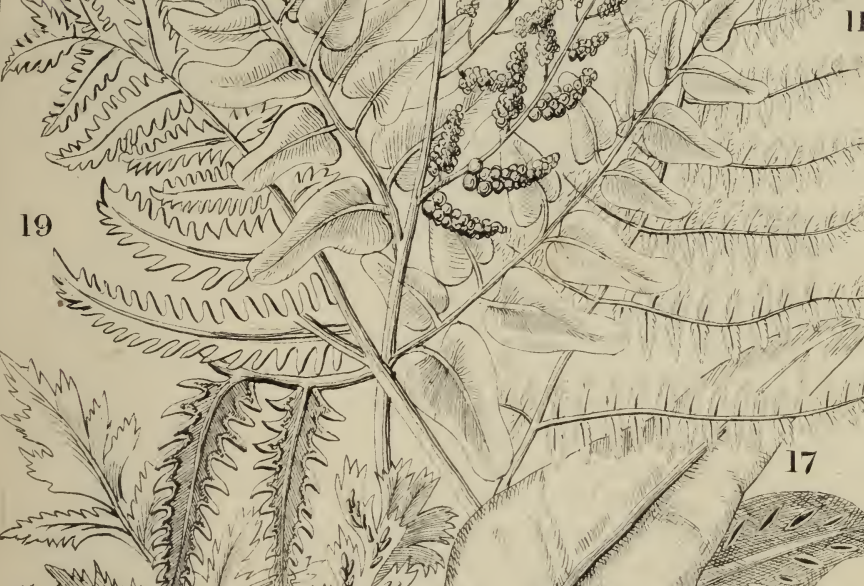

cond

" why $=5(2)$

Antents

$13 \xi_{1}^{3}=1$ (3)

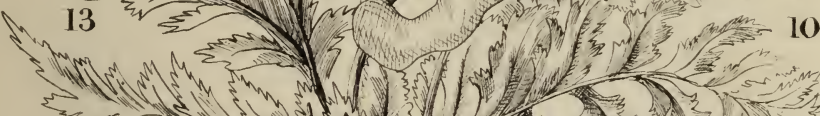

\section{7}

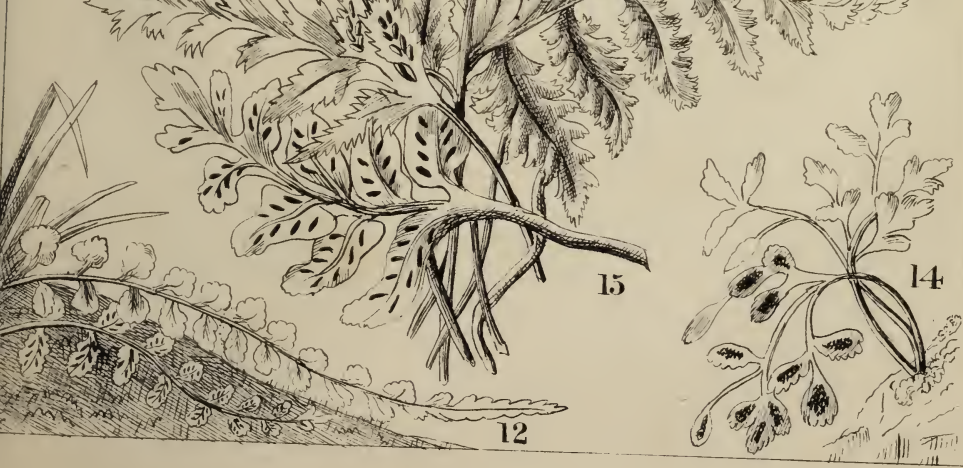



divide into branches above. Its height is from three to ten inches. The bags of spores on the clustered spike are quite distinct. There are generally as many branches on each side of the spike, as there are leaflets on each side of the frond. The stalk of the spike is about as long as the branched part. There are from three to seven pairs of leaflets. The stalk is smooth and hollow, and nearly as long as the frond and fruit-bearing spike. The plant rises up every year and dies before winter. It has a truly fibrous root, which, as in the case of the preceding species, is very different from every other Fern. There is a sheath-like scale to the stem, more like that of the horsetails, (Equiseta) than of the Ferns.

Great medicinal virtues are ascribed in olden times to Ferns. As the divisions of this have a resemblance to certain phases of the moon, and as that satellite of the earth was considered to have great influence on human affairs, the superstitious and credulous were wont to gather it by moonlight. In the days of witcheraft and wizards, those who dealt in the magic arts would, doubtless, be seen searching for this Moon Fern by moonlight, as they considered the herb would then be more potent, and its wonderful virtues enhanced. Not only did such persons endeavour to deceive others, but were themselves deceived into a belief, that strange things were brought about by peculiar plants picked at the right time. In this enlightened age we have ourselves been told, that if we wish to hoard apples, we must be sure to take them off the tree at the rise of the moon. Parkinson says "It hath been formerly related by impostors and false knaves, and is yet believed by many, that it will loosen locks, fetters, and shoes from those horses' feete that goe in the places where it groweth, and have been so audacious to contest with those that have contradicted them, that they have both known and seen it to do so. But what observation soever such persons doe make, it is all but false suggestions and mere lyes." Jacobus de Manliis relates "Some of the moderns have said, that in St. John's night some go to the place where the Fern rises and there stand for three hours and say that within that time the Fern bears flower after the seed. God knows better. Deus melius scit." We do not apprehend, that any medicinal virtue is attached to it at the present dav. 
This is not a very conspicuous Fern, and is generally distributed throughout Great Britain, though rather local. It generally grows in $d r y$ open heaths and elevated pastures, where the soil is either sand or peat. The same position is unfavourable for other Ferns except Brake. Moonwort is rather difficult to be cultivated. Some have considered it a parasite, attached to grass roots. Care should therefore be taken not to separate it from the surrounding roots. It should also be planted before it begins to raise its fronds, and not be placed in any rich mould. Too much moisture or drought is alike to be guarded against. We have only as yet ascertained that it is to be found near Lambert's Castle, to the south of Fishpond bottom, growing around the furze bushes, in Hawkchurch parish, and in New Park, in Axminster. Very probably it is also to be met with on Colyton, Stockland, and our other high hills, on a sandy or dry peaty soil. The most likely periods of the year for finding this plant are the months of May, June, and July. 
II.

OSMUNDS. OSMUNDACEA.

Ir we judge merely by the ordinary appearance of this Suborder, we should feel satisfied, that all plants ranged under this head were true Ferns. The curled-in buds, the divided fronds, the rust-red summits of the branches seem to denote such to be the case. There is, however, one character yet wanting, and that is the elastic ring which encircles the bags of spores. When placed under a microscope, this cannot be seen, or if visible, it only resembles a little lid, and does not run round the middle of the bag. These are commonly called Flowering Ferns, not because they have true flowers, but because their fructification is conspicuous from being placed on the branched extremities, and not on the back of the frond. This, as well as the preceding, is a very small Sub-order in every country, and we have only one genus, and one species of that genus. This is 1 . Flowering Ferns. Osmunda. Fruit in clusters. No vestige of an elastic ring.

"Many such there are,

Fair ferns and flowers, and chiefly that tall fern

So stately, of the Queen Osmunda named,

Plant lovelier in its own retired abode,

On Grasmeres beach, than Naiad by the side,

Of Grecian brook or Lady of the Mere,

Sole sitting by the shores of old romance."-Wordsworth.

Plate II, fig. 2.

Royal Flowering Fern. Osmunda Regalis. This gigantic Fern luxuriates in great profusion in Higher Beaver, and the Batches, in the parish of Axminster; in the dells of the parish of Uplyme, especially on Hole Common; and in a boggy wood close to Ridge, in the parish of Stockland. It is found raising its head to the height of seven or eight feet, and, with its splendid foliage, and its rusty-red spikes of fruit on the summit of its stalk, cannot fail to attract the admiration of every lover of nature. "Osmund" is derived from the Saxon word mund, signifying strength. The caudex or stump, when cut through, has a whitish centre or core, called by old Gerarde in his "Herbal " the heart of Osmund the waterman. One of the boatmen told Newman that 
when Sir Walter Scott visited the lakes of Killarney, and observed this Fern fringing the river between the lakes, the Baronet, who had scarcely before uttered a syllable in praise of the scenery, exclaimed, "This is worth coming to see."

The foliage of this plant has some resemblance to the leaves of the ash tree. The pinnæ are opposite each other, and furnished with distinct leaflets, which are not opposite, but alternate. The leaflets are generally oblong, though sometimes the lower and younger ones are lobed at the base, and the edges are serrated. The plant, in its early stage, has a reddish cast, and seldom appears until the frosts have ceased. The root-stock (caudex) from whence the fronds arise, is often one or two feet above the surface of the ground, which gives it the appearance of a Fern tree. The stalk is woody, as long as the frond itself. The side-veins of the leaflets of the barren fronds vary from those of the fertile ones. The former fork near the mid-rib, and the higher or both of these veins fork a second time. In the fertile fronds there issue from the mid-rib on each side lateral veins, which do not divide, nor reach the margin. The roots are extremely difficult to eradicate, and we have found that we need the help of a sturdy labourer with his spade and pickaxe to extract this firmly seated plant. The stiff spongy soil seems to resist the efforts of the amateur, and requires a powerful arm to ensure success in procuring a thoroughly good specimen for the fernery. The fructification at first lies compact and close together. When bright summer comes and the nipping frosts have passed away, then we see the red branches expanding, and the Flowering Fern in all its glory. Even a careless observer cannot fail to notice how much larger and grander are the leaflets of this than any other Fern.

This plant delights in bogs and wet places. They succeed best in its cultivation, who plant it on the brink of pools and streams. This has been done very successfully by the Copleston family at Offwell, who have ornamented their fish ponds and brooks with this handsome Fern. It was taken from some neighbouring swamp, where it flourished in great luxuriance. It will also thrive in gardens and plantations if well supplied with peat or bog earth, and furnished with abundance of moisture. Though it grows in open 
fields in wet places, we should recommend a shady situation, if placed in a rather đry position. A large sod of earth should be taken when we transplant it from its native haunt.

Various fables have been circulated respecting this plant. There is a story, that when the Danes used to make inroads into Britain, Osmund was a waterman at Loch Tyne. He had a fair and lovely daughter, and a fond and affectionate wife. When tidings reached him that a horde of these ruthless intruders were approaching his humble residence, he.was at first perplexed what to do. Soon he determined to ferry his partner and child across the sea to a small island and hide them beneath this magnificent Fern. Scarcely had he done this, when the Danes obliged him to convey a formidable party to a different direction. Thus his child and beloved wife escaped their observation and were saved unscathed. Grateful for the mercy received, the daughter gave to it her father's name, and it is called Osmunda Regalis. Gerarde remarks, "The root and especially the heart or middle part thereof boyled or else stamped and taken with some kind of liquor, is thought to be good for those that are wounded, dry beaten, and bruised, that have fallen from some high place. The tender sprigs thereof at their first coming forth are excellent good unto the purposes aforesaid, and are good to be put into balms, oyles, and consolidations or healing plaisters, and into unguents appropriate unto wounds, punctures, and such like." Such a value did our sage forefathers set on this and many other herbs and vegetables.

This Fern grows, in addition to the places already enumerated, in a boggy wood near Avishays, in the parish of Chard, also in Monkton Wylde and Offwell. Other localities of this and rarer Ferns, will be given at the end of the book. 


\section{POLYPODS. POLYPODIACEA.}

Family I. Polypodies. Polypodiex.

Fructification on the back of the frond. No cover to clusters of fruit. This family is subdivided into two genera.

1. Gymnogramme. Clusters oblong or linear. Of this genus none grow in the neighbourhood.

2. Polypodies. Polypodia. Clusters round, hemispherical. Of this we have one species.

"Here finds he on an oak rheum-purging polypode And in some open place that to the sun doth lie, He fumitory gets, and eyebright for the eye, The yarrow, wherewithal he stops the wounded gore, The healing tutsan then and plantane for a sore; And hard by them again he holy vervane finds, Which he about his head, that hath the megrim, binds."Drayton's Polyolbion.

\section{Plate I, fig. 3.}

Common Polypody. Polypodium vulgare. Our hedge banks and old trunks of trees are covered with this in all directions during the winter months. While in the icy regions Franklin and Parry could behold no green spot or leaf; and while in the burning deserts of Africa, the parched and exhausted traveller can only see oceans of sand, and a mere tiny moss is most exhilarating and refreshing, we pass by unheeded this cheering production of the great Creator at a season when all seems dreary and desolate. The frond of this Fern is strap-shaped and pinnatifid, that is, deeply divided, but not quite to the mid-rib, for then it would be pinnate. Its clusters of fruit are remarkably large. The leafy part averages eight inches in length. The side-veins of the leaflets are alternate and divided into two or three branches; the highest branch of the vein is fruit-bearing, the others end in a knob, and thus become club-shaped. The roots or underground stems are about the size of our little finger, and creep underneath the earth or on the bark or moss of old trunks of trees, and adhere to them with great tenacity. These branch here and there with many fibres underneath, and are covered with dense brown scales, which peel off at a year's end and become quite smooth. From the 
breaking off of the fronds of the previous year, there appear in the roots many a scar, like those of a valiant soldier, who has been bravely engaged in the defence of his beloved country. The stalk is usually as long as the frond itself, and the fructification is confined to the upper part, and is at the end of its vein. The edge of the leaflets is generally not cut, though they sometimes are serrated and notched. The young fronds are often inconspicuous during the summer, and the beauty of this plant appears in the winter months.

This Fern has a very wide range. It thrives in almost every part of Europe, and though it shuns the torrid zone, is found in the northern regions of Asia, and is not altogether excluded from Africa. Common as it is, it has its peculiarities. It does not frequent the open heath or common. It rather delights in the works of man, and settles on some ancient building, ruined castle, or abbey, or quietly reposes on an old wall, hedge, or bank. It does not hug in its embrace the lofty forest tree, but clasps some decayed and stunted pollard oak or ash with great pertinacity, and hastens on its ruin. Our forefathers used to make a distinction between the Polypody of the oak and the Polypody of the wall, but they are identically the same plant, with this difference only, that generally when growing on the wall, it is a more stunted and starved specimen.

It is almost unnecessary to make any remark respecting its cultivation. Let the roots be extracted in a compact form and placed on a rockery, or if firmly adhering to an old stump, let a slice be sawed off where the roots are thickly matted together, and it will most certainly thrive. Some of our city friends suspend it in a wooden basket, wherein is placed bog moss, dead leaves, and sand, and consider it, thus placed, very ornamental to their greenhouses. If such an attempt be made, the gardener should attend to ventilation and a due supply of fresh air.

Some of the old writers ascribe great medicinal virtues to this plant. Dodonæus relates "That the inhabitants of the Rhine and Mosa, by using a decoction of it, are freed from those tumours in their hands, feet, knees, and joints, wherewith they are much troubled." Are any low-spirited, and disturbed by night? Parkinsou declares " That the distilled 
water of the roots and leaves, taken many days together, is commended against melancholy and fearful or troublesome sleeps and dreams." He also adds "That the roots beaten small and applied to the nose, cures the disease called Polypus." The medical men of the present day very properly object to all these nostrums, and Sir James Smith remarks, that the medicinal properties of the Polypody "are not enough to make it worth enquiring whether that of the oak, or that of any wall or cottage be more endowed with them." Even old Gerarde designates them, "old wives' fables, fit only for writers who fill up their pages with lies and frivolous toies."

The Plant had its name from two Greek words $\pi 0 \lambda v s$ movs, having the signification of many feet, because it has many creeping roots. Gerarde says "that the Grecians call it Polypodium, because the holes of the fishes Polypi appear in the roots." The classical writers, Dioscorides and Pliny state, "that it is so designated from the suckers or feelers of Polypi, which resemble curls of hair." There is certainly something like the feelers of Polypi in the underground stem and roots.

\section{Family II. Shield-Bearers. Aspidiece.}

Some travellers have mentioned a most remarkable plant of this family, the Tartarian Lamb, Aspidium or Cibotium Baromez. This, from its peculiar colour and form, was supposed to be a vegetable animal. Struys, an old traveller, says "On the western side of the Volga there is an elevated salt plain of vast extent, but wholly uncultivated and uninhabited. On this plain grows the Boranez or Bornitsch. This wonderful plant has the shape and appearance of a lamb with feet, head, and tail distinctly formed. Its skin is covered with very white down, as soft as silk. The Tartars and Muscovites esteem it highly, and preserve it with great care in their houses, where I have seen many such lambs. The sailor who gave me one of these precious plants, found it in a wood, and I had its skin made into a waistcoat. I learned at Astracan, from those who were best acquainted with the subject, that the lamb grows upon a stalk three feet high; that it turns itself round and bends down to the herbage, which serves for its food. 
They also said, it dries up and pines away when the grass fails." The real fact of the matter is, that when other vegetation dies, this plant dies also. The creeping underground stem or root is covered with yellow down, like wool. When these stems, branching in different directions, are placed in an inverted position, they resemble the legs, horns, body, and tail of a sheep. So much for the Tartarian lamb.

"Cradled in snow and fanned by Arctic air,

Shines, gentle Barometz, thy golden hair;

Rooted in earth each cloven hoof descends,

And round and round her flexile neck she bends;

Crops the grey coral moss and rosy thyme,

Or laps with hoary tongue the melting rime;

Eyes with mute tenderness her distant dam,

Or seems to bleat a vegetable lamb."-Darwin.

This family is divided into two genera.

\section{Genus 1.}

1. Shield-Ferns. Lastrea. Cover round or kidney-formed, having a slit in it, and attached by the inmost point of that slit, (sinus.) Side-veins of leaflets distinct after leaving the mid-vein.

$$
\text { Plate II, fig. } 12 .
$$

1. Sweet Mountain Fern. Lastrea Montana. He who would gather this Fern, must not remain in the lowly valleys, but ascend aloft. It is called Mountain Fern because it thrives in more elevated situations. Beyond the regions of the Axe, at Fingal Bridge in Dartmoor, it thickly lines a rippling stream and greatly tends to beautify the scenery, At Lynmouth, too, that most lovely spot in North Devon, when we have wended our way to Watersmeet, we behold this odoriferous Fern in the greatest profusion. It is rather a scarce plant in our district. When gently squeezed, a sweet fragrance issues forth from the numerous glands on the under surface, and hence the name. With regard to the covers of the fruit, they are not often seen, or rather it would be more correct to say that they are very delicate and very soon fall off. The frond is pinnate, and the pinnæ are deeply cut, (pinnatifid) more than half-way to the mid-rib. The leaflets or segments are rather blunt at their summit, oblong in form, and very slightly, if in any way notched at their edges. The stalk is very short and densely covered 
mith light scales. About the middle of the frond the branches or pinnæ gradually become shorter and shorter, until the last becomes less than an inch long, and close to the very stem or stump. (caudex) It should also be observed, that as they taper downward, they become more and more distant from each other.* The lowermost, in fine specimens, are often an inch and a half or two inches apart, and triangular in form. This plant may be mistaken by the uninitiated for the Male Fern, but if attention be paid to the circumstance of the remarkable narrowing down of its branches, and to its clusters of fruit being much nearer the edge of the leaflet, the difference of the species will be easily discovered. It varies from ten inches to two feet long and more. The lowest pair of branches often point downward. If we hold the frond up to the light, little transparent pores are sometimes visible, as in some of the St. John's Worts. A curious fact is also worth noticing, that when the Fern begins to unfold, the branches or pinnæ appear quite straight and not coiled-in at their extremities, as is generally the case with the Fern tribe. The side-veins of the leaflets alternate on the mid-vein with clusters of fruit near the extremity, but not, as in the Common Polypody, at the extremity itself. If the veins are forked, both veins have these clusters, and, in this respect, also, differ from the Male Fern. The whole plant is likewise more pliant and flexible.

This Fern is easily cultivated, if placed in bog earth or yellow loam, and supplied with abundance of moisture. It grows here most frequently on high ground upon black bog earth, near a rippling stream. Sometimes it locates itself in damp, open heathfields.

We have found it on a wet hedge-bank overhanging a little stream in fields to the north of Avishays, near Chard; on the bank of a gully near Alston, on Birch-hill Common, in the parish of Chardstock; also at New Park, in Axminster parish ; and a little further onward in Hawkchurch; in a boggy wood in the north-west of Uplyme; and at Ham Lane, and a hedge-bank near Colmar Copse, in Stockland. We learn that it is within three miles of Charmouth, probably near Monkton Wylde.

The old Herbalists do not seem to have noticed this Fern. We have not therefore received any account of its healing

* Plate II, fig. 12, not correct in this respect. 
powers. Ray, however, appears to have been acquainted with it, and denominates it "The Male Fern of the heathfield Dunsmore."* With regard to its geographical position, it is distributed throughout England in elevated situations. It is not, however, confined to hills, for there are many instances where it is found on waste grounds, in more level countries, and, especially, on the borders of very damp woods by the side of a little stream. In Ireland it is scarce. It extends throughout the Continent of Europe as far north as Norway, and as far south as the Asturias in Spain. Hooker calls it "Nephrodium Oreopteris."

"Though in Heaven the trees

Of life ambrosial fruitage bear, and vines

Yield nectar; though from off the boughs each morn

We brush mellifluous dews, and find the ground

Covered with pearly grain, yet God hath here

Varied His bounty so with new delights

As may compare with Heaven." -Milton.

Plate I, fig. 7.

2. Male Fern. Lastrea Filix mas. In this, our family of plants, we have not only the Male, but the Lady Fern also. The one now before us is the Male, so called because it stands up firm, robust, and sturdy, not ashamed to lift up its head amidst the vegetation by which it is surrounded. May we not learn, even from nature's works, to be stedfast in purpose, and firm in conduct, not vacillating and giving way on every trifling occasion. This species is scattered over every part of the kingdom, and is most abundant in rich soil in shady situations. A visitor would be richly delighted by beholding this plant in our district in the greatest perfection. Though sometimes only a foot and a half high, it is not unfrequently as high as four feet. It is sub-bipinnate or branched, and the branches nearly branched too. The leaflets are strap-shaped or oblong, and the ends rounded. The clusters are from three to eight on each leaflet, placed in two rows, near the base, and distant from the edges. When about a foot high, and the fronds are not in the least expanded, the stalks are richly covered with reddish yellow scales, and the summit is curled together like an ammonite or a hairy caterpillar, which folds itself up,

* Filix mas ericoti Dunsmore Petiveri. 
when any attempt to touch it. When the frond begins a little to expand itself, then the stalk and greater part of the plant keeps itself perfectly upright, with nearly two or three inches of the summit hanging forward and assuming the appearance of an elephant's tusk. It is very stiff and erect, growing shuttlecock-fashion around its trunk. The covers of the fruit are remarkably permanent. The branches (pinnæ) are numerous, narrow, and tapering, sometimes with a few of the lower segments or divisions forming perfect leaflets. The lobes or semi-leaflets are very slightly cut or nicked at the edges, sometimes, in shady places, more deeply, as in our figure (Plate I, fig. 7,) and then it is var. incisa or affinis. The fructification is very abundant, but confined to the upper part of the frond. The upper and lower leaflets of each pinnæ are nearly of the same size. The side-veins of each leaflet are branched, and the upper one only bears fruit, which is quite contrary to what happens in the preceding species. The lower branches (pinnæ) are considerably shorter than those of the middle of the frond, but never dwindle to the diminutive form of the Mountain Fern (Lastrea Montana.) The root is strong, firmly fixed to the ground, and of a blackish colour. Sometimes the trunk or stock is several inches above ground and thus resembles a Tree Fern.

This is not confined to our own country, but is equally common in every part of Europe and Northern Asia. It was not unknown to the ancients. All writers give it the appellation of Male Fern (Filix mas.) Newman gives the name of its genus, Dryopteris ; Hooker, Nephrodium.

The Siberians boil this Fern in ale, and are fond of the flavour which it imparts. In Norway, the curled leaves are boiled and eaten like asparagus, and the larger leaves, infused in hot water, afford an acceptable fodder and litter for cattle. The ashes of this and of Brake (Pteris Aquilina) are used by the manufacturers of soap and glass. It was also rended in olden times for charms against the dealers in the "black art." Divers vagabonds were in the habit of preparing from its root, and from its young unbent, and yet unexpanded, branches, the "lucky hands," or "St. John's hands," which they sold to ignorant people both in town and country, as preservatives against witchcraft and 
enchantment. "It is a pity," says an old writer, "that such remedies will not also protect us against death." Parkinson sagely remarks "The seed which this and the Female Fern do bear, and to be gathered only on Midsummer eve at night, with I know not what conjuring words, is superstitiously held by divers, not only mountebanks and quacksalvers, but by other learned men, (yet it cannot be said but by those that are too superstitiously addicted) to be of some secret hidden virtue, but I cannot find it exprest what it should be." Without dwelling on the imaginary virtues of this plant, which exist only in the minds of the credulous and superstitious, we may venture to state that God in His mercy has given us this excellent herb as one of the best remedies for tænia or tapeworm. It appears to have been used by the ancient physicians Theophrastus, Dioscorides, and Galen. Professor Christison, in the Edinburgh Monthly Journal for June, 1852, and July, 1853, has shown that it is almost uniformly successful in the form of an oleoresinous extract, obtained by percolation of the root with ether. He, indeed, commends it as a less disagreeable and more efficient anthelmintic than the Abyssinian Kousso, the continental pomegranate, or the American turpentine.

There is no difficulty in the cultivation of this Fern. Supply it with rich regetable mould in a shady place, and keep it rather moist, and it will flourish. It needs not so much water as either the Royal Flowering or Mountain Fern.

Newman places the three next species under a different genus, which he calls Lophodium (plumed or feathered.) It seems better and simpler to retain them among the Shield Ferns. (Lastrea) Let it however be remembered with regard to these, that the first upper branchlet (pinnule) of the lowest pinne is much shorter than the first under branchlet. Vid. Plate I, fig. 8 and 9, and Plate II, fig. 10.

* * "Sweet to muse upon his skill displayed,

Infinite skill in all that he has made,

To trace in nature's most minute design,

The signature and stamp of power divine,

Contrivance intricate, expressed with ease,

Where unassisted sight no beauty sees."-Cowper. 
Plate I, fig. 8.

Dark-scaled Shield Fern. Lastrea dilatata. We are now come to a portion of the Shield Ferns which assume a feathery or plumose appearance. This and the two following species are a great ornament to our shady woods and deep gullies and hedge-banks. This plant grows in great luxuriance in this locality. It thrives in rich, moist, and shady situations. None of our Ferns exceed it in height except the Common Brake (Pteris aquilina) and the Royal Flowering Fern. (Osmunda Regalis) It is tripinnate, that is, not only the branches are divided, but the branches of the branches likewise. There is another peculiarity in this Fern, that the two or three lowest pinnæ or branch-

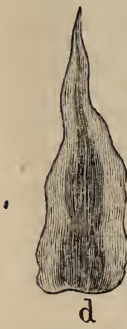
es are always shorter than those above. The scales on the lower part of the stalk have likewise a dark centre with transparent margins as represented in this woodcut. The root-stock is large, upright, sometimes a foot above the surface, covered with dark scales. The leaflets are deep green, generally drooping, never having the edge curled upwards. The lobes or divisions of the leaflets are blunt, with a little spine on each. The stalk is thick at the base and as long as the frond, covered with these dark centred scales. The frond is egg-shaped or lanceshaped, Plate I, fig. 8. The lower pinnæ are triangular. The upper are less so. The uppermost are nearly linear. When the plant is in bud and not quite unfolded, it does not hang its summit down, like a shepherd's crook or a rhinoceros' trunk, as is the case with the Male Fern. The end of the bud turns to the right and left, and makes a loop or ring, and assumes with its dark scales a very grotesque and peculiar form. The covers of the fruit are circular with a slit in it, (the mark of the genus) and when seen through a lens or microscope, are found to have stalked glands on the edges, as represented in woodcut c. page 9. The frond is scarcely ever erect in growth. The branches are nearly opposite. The clusters of fruit are distinct. The veins are branched, and the fruit is always on the upper branch of the vein. As there is some difficulty in discerning the difference between this and the two following species, we call attention to the four following marks of distinction. 1. In no case, 
except in seedlings and starved small specimens, is the frond triangular. It is egg-shaped or lance-shaped. The three lowest pinnæ, as has been already observed, are shorter than the fourth, and the lower of each shorter than the one above. Thus if the lowest were seven inches, the second would be about seven inches and three quarters, the third eight inches and a quarter, the fourth nearly nine inches. 2. The scales have a dark centre with a transparent edge, as represented in woodcut $d$. This may not always appear at first. If we keep the plant for a few hours, we shall find it take place, or we shall find some on the plant having the middle of the scale darker than the outer part. Babington remarks, "The largest scales of the full grown plant should be examined." 3. The leaflets are more or less drooping. They may sometimes be flat, but never with their edges curled upward. The whole frond is arched or curved in its position. 4. The covers of the clusters of fruit, when examined under a glass, will be found to have stalked glands to their edges. This, as all other microscopical investigations, must be done carefully, or we shall ourselves break off the delicate glands.

It seems very doubtful whether this plant, common in our woods and copses, has been alluded to by our old Herbalists, or even Ray. Perhaps Gerarde, when he describes what he calls "a branched Male Fern, with toothed pinnules,"* speaks of this species. He says, "The side branches, the longest being the third pair from the root, were nine inches long, and shorter and shorter toward the top, in number about twenty pair." Whether Ray alluded to this or the following species, is not clear, Newman thinks to the latter. It is not at all likely that he passed by unnoticed all three of this group. In some instances, especially in dry spots, it is very stunted: in other cases five feet high, always ornamental and elegant in appearance. The Fern is common throughout Europe. Francis also states, "that it grows in North America from Pennsylvania to Virginia.

If any person wishes to adorn a garden with this child of nature, it can be easily done by taking up the roots carefully, planting them in loose vegetable mould in a shady spot, and supplying them with moisture. Newman calls this Fern Lophodium Multiflorum.

* Filix mas ramosa pinnulis dentatis. 
"Then spring the living herbs, profusely wild, O'er all the deep green earth, beyond the power

Of botanists to number up their tribes:

Whether he steals along the lonely dale

In silent search, or through the forest, rank

With what the dull incurious weeds account,

Burst his blind way or climbs the mountain rock,

Fired by the nodding verdure of its brow."-Thomson.

\section{Plate II, fig. 10.}

4. Hay-scented Fern. Lastrea fenisecii. Dr. Solander, the celebrated Botanist, who accompanied Captain Cook in his first voyage, left behind him a dried specimen of this plant. It is in the Banksian Herbarium. He it was who saved a large party from destruction by cautioning them against sleeping, when they were ascending the heights and colder regions of the mountains of Terra del Fuego. He, too, proved how much easier it is to give advice than to practise it, as he was with difficulty kept awake during that perilous expedition. His name for the plant was Polypodium æmulum. It was only recently that we discovered this and the next species, the Spinous Fern, (Lastrea spinulosa) growing in this locality. A ramble in the North of Devon, where these plants were known to grow, led us to pay more particular attention to some distinctive marks, and the discovery of one of these at a distance, was the means of our lighting on them almost close to our own doors. Thus many travel into distant lands to behold beautiful and romantic scenery, and when they return home, perceive that it is far exceeded by the hills and dales, and purling brooks, and winding streams, which glide through the lovely valleys of Devonshire.

The frond of this Fern is decidedly triangular, and differs from the preceding species, the dark-scaled Fern, in these respects. The dark-scaled Fern has always, unless in stunted specimens, the lowest branches (pinnæ) shorter than two or three above it. The leaflets bend downwards, and the scales in the lower part of the stalk have a dark centre. In this plant the lowest branches are the longest, and hence it is triangular. The leaflets at the edges curl upwards, and their middle appears hollow. The scales are of the same light brown colour throughout, narrow, lance-shaped, and 
torn frequently at the summit. The covers of the clusters of spores are without stalked glands, but jagged at their edges with a few globular ones, that are quite stalkless. The buds of the fronds before they unfold, are regularly rolled together, (circinate) and do not assume the appearance of the preceding species. The lobes of the leaflets are serrated and end in a spine. The stalk is generally dark purple, very stiff and woody,

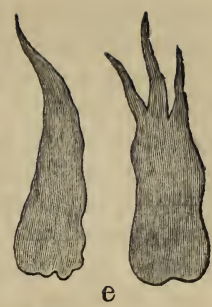
with the transparent scales more closely adhering to it. The plant has a very elegant appearance, sprinkled over with minute glands, which, when pressed, and when any part begins to decay, emit the scent of hay. It seems to require elbow room. Hence we find it where the coppice is not very thickly matted together. It is also a perfect fish, and loves to locate itself where the water trickles down copiously. This Fern is decidedly an evergreen, of compact growth, of a grass-green colour, and appears to great advantage in a garden and a greenhouse. In Newman's work there is this description given by Mr. Ogilvy of Dublin, "This is in my opinion the most beautiful of our robust Ferns. In style of growth, and elegance of form, it is most striking. It presents two tiers of fronds, if I may so describe them, the lower more pendulous, the upper more erect, and it is on the more erect fronds that the fructification is most perfectly developed. The dark purple stem contrasting with the light green and crisped appearance of the pinnæ, gives a peculiarly elegant appearance to the plant. It likes the seclusion of trees, and places where it is not pressed by other vegetation."

This species is of a hardy nature, and if supplied with sufficient moisture and shade, will not require much trouble in cultivation. It should be in a loose soil without any admixture of clay or marl. If in a pot, it would be of service to lay at the bottom the bog moss (Sphagnum) and pebbles, and above, black bog, or peat, or sand. When regularly watered, the plant will thrive, and the liquid will not stagnate, but percolate through the moss and pebbles. It will also flourish in a rockery of sandstone.

The old Herbalists and Ray do not seem to have noticed the distinctions of the three species, the dark-scaled, the 
hay-scented, and the spinous shield Ferns, (Lastrea dilatata, fænisecii, and spinulosa.) We must not be surprised at this, when Hooker and Bentham, two eminent Botanists of the present day, pronounce these three to be only varieties of the same plant. We agree with Moore, Newman, and Babington, in thinking that they are distinct. In some cases they may approach very near to one another, still there are certain definable lines of demarcation between them. Mr. Bree, in Cornwall, and Mr. Lowe, in Madeira, were the first to call attention to this plant, if we except Dr. Solander. The one called it recurvum, curved back in allusion to the turning up of the edges of the leaflets, and the other fænisecii (of cut hay or hay-scented) because of the scent of hay which it emits. It is found in various parts of England, especially Cornwall and Deronshire. Mr. Lowe noticed it in Madeira, and Newman adds, the Azores and the Cape de Verd Islands. As has been already stated, there are a variety of names given to this species. Newman calls it Lophodium fænisecii. Hooker, Nephrodium spinulosum var. æmulum. Moore, Lastrea æmula.

This is one of our scarcest Ferns. We have found it in a boggy wood on the north-western side of Uplyme, and at Greenway-head, near Monkton Wylde, on a hedge-bank close to the turnpike road between Axminster and Charmouth.

\footnotetext{
"Thy desire, which tends to know

The works of God, thereby to glorify

The great Work-master, leads to no excess

That reaches blame, but rather merits praise.

For wonderful indeed are all His works,

Pleasant to know, and worthiest to be all

Had in remembrance always with delight."-Milton.

$$
\text { Plate I, fig. } 9 .
$$
}

5. Spinous Fern. Lastrea spinulosa. This Fern is more erect than the two preceding species. Neither do its leaflets curl upwards, and if they slope at all, it is very slightly downwards. All three are tripinnate, i.e. the pinnules of the pinnæ are pinnate, or, in other words, the branchlets of the branches are branched. Sometimes in this species the frond is only bipinuate, and Hooker so describes it. The lower 
part of the stem is not, as in the case of the other two, thickly covered with scales, but sparingly, and these aro round, or broadly egg-shaped and transparent. The stem is stout, the root creeping, and the plant does not lie compactly together, but is of a stragling growth. The frond is long, narrow, and the six lowermost pinnæe on each side are of the same length, and form therefore a parallelogram. After this the frond begins to taper to a point, and the pinnæ, as they approach the summit, become shorter and shorter. The under pinnules of the first pair of pinnæ are generally twice as long as the upper

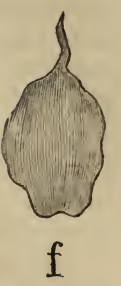
ones. The clusters of seeds seem to be distinct and perfectly separate, and generally form a regular double line. When the pinnule is deeply divided into leaflets or distinct lobes, then each branch of the side-vein has a cluster of seeds, as in the Sweet Mountain Fern. In this case the double line of clusters does not appear so regular to the eye. Each lobe of the leaflet has a little awn or spine, and hence it is denominated the Spinous Fern. The branches are nearly, but not quite opposite each other, and the naked part of the frond is as long as the leafy part. Some have considered the three Ferns last described to be identical. We consider that they may sometimes approach each other, but a well practised eye will always discern a difference. The creeping root, roundish egg-shaped transparent scales, the glandless covers, the upright position, its peculiarly light green appearance, all combine to point out the Spinous Fern, (Lastrea spinulosa.) When we speak of the covers, of course they must be seen through a lens or a microscope, and then it will be found that they differ from woodcut $c$, page 9 , in not having glands. This Fern is by no means to be despised, and in its general appearance has considerable grace and symmetry. Since, however, the upper part of the frond is of a frail and delicate texture, it is frequently shattered by the wind and other causes, and is therefore not so ornamental for cultivation.

In closing our remarks on this species, we may venture to remark, in this utilitarian age, that the student of natural history is pursuing no useless occupation, when he devotes himself to the contemplation of the beauteous works of God. 
The ear is disciplined by music, the hand by the nice touch, as in the case of the blind, so is the eye by scanning, even in little things, the varying course of nature's works. Surely it is most desirable that we should not be insensible to the regular order and nice distinctions which our great Creator has maintained in every portion of the vegetable creation, from "the cedar in Lebanon to the hyssop that groweth on the wall." God has given us our sight to turn it to a useful account, and to discriminate all His works, and to find out "how in wisdom He hath made them all."

The old books, for the same reasons as were mentioned in the preceding species, do not speak of this plant. With regard to its cultivation, it requires a light sandy or peat soil. It needs even more water than the Hay-scented Fern, (Lastrea fænisecii) and should never have a bright glaring sun. Nature speaks for itself, when we notice how it grows in wet shady woods, in a loose crumbling soil.

We have only found this in two places, in a wet copse not far from Avishays House, near Chard, and in a boggy wood on the north-west side of Uplyme parish. A friend also mentions Langmoor wood, near Charmouth.

Newman gives it the name of Lophodium spinosum, and Francis designates it Aspidium spinulosum; Moore calls it Lastrea cristata var. spinulosa ; Hooker, Nephrodium spinulosum var. bipinnatum.

\section{Genus 2.}

Prickly Ferns. Polysticha. Cover circular, attached by the centre, and free at the edges. First upper leaflet larger than the next, and also than the one immediately below it. The little bristles on the leaflets of this tribe sufficiently show why they have the English name of Prickly Ferns. The classical name, signifying "many ranks," was probably given because the back of the frond is covered with dense masses of fructification. The chief distinction between this and the Shield Ferns (Lastrea) is that the covers have no slit, and are attached by their centre. Though the species differ much in their form and appearance, and though there are many varieties, all the leaflets have, more or less, on the side opposite the main rachis, a little lobe technically called an ear or auricle. Smith and others used to unite the 
Prickly Fern (Polystichum) and the Shield Fern (Lastrea) under the common name Aspidium. The difference in the covers can quite account for their being divided into two groups.

"There's beauty all around our paths, If but our watchful eyes

Can trace it 'midst familiar things,

And through their lowly guise."

Plate I, fig. 5.

1. Common Prickly Fern. Polystichum aculeatum. Newman says "The European range of this Fern extends to every country except Spain, where one would rather suppose it to be unobserved than absent, since it commonly occurs throughout France, and ascends the Pyrenees to the height of 2500 feet. It is found in Asia, Northern and Southern Africa, and North America. In North America it is extremely rare, but perfectly identical with our British plant." In this district this species is less common than the following one, the Angular Prickly Fern.

The Prickly Fern has a short stalk (stipes) which is densely covered with scales. The fronds are stiff, one to two feet high, lance-shaped, or even linear. The leaflets nearest the rachis or mid-stem of the frond, on the upper part of the lower pinnæ, are much longer than the one next to it, and often overlap the base of the pinnule next above it. The leaflets also have no distinct stalk, but are either decurrent, that is, one leaflet seems to run into the other, or have a thick wedge-shaped base, by which it is attached to the rachis. If we hold up the Fern, we shall observe that the lowest part of this leaflet is close to the mid-stem of the frond, while the light will appear in the upper part. The pinnæ are alternate. The scales are not only upon the stalk, but also on the mid-stem or rachis, where they are much narrower and almost linear. The whole plant is tough and leathery, and not only outlives one, but sometimes two or three winters. The different years' production may be distinguished by their difference in colour, and their browner aspect. It is also more erect than the succeeding species, 
and of a more rigid texture. The plants are fully formed about Midsummer, and the fructification appears quite ripe a month or two later. There is a little projection or ear (auricle) to the leaflets, especially those nearest the midstem at the bottom and outer edge of these leaflets. This is still more apparent in the next species. Often the back of the upper part of the frond is thickly covered with clusters of spores. The side-veins of our Prickly Ferns are alternately branched. The branches never meet, but reach the edge of the leaflet. The masses of fruit are seated on the uppermost branch of the side-veins. To each serrature there is a sharp and strong bristle, and hence the name Prickly Fern.

There is evidently a description of the Prickly Fern (Polystichum) in Johnson's edition of Gerarde's work, page 1130. It is described* as "the not branched Male Fern, with broad auricled spiny pinnules, each leaf, especially those next the stalk" (rachis) "having on that side farthest off the stalk a large ear or out-growing, ending with a sharp prick, like a hair, as doth also the top of the leaf. Some of the sides of the leaf are also nicked, ending with the like prick or hair. Each leaf hath two rows of dusty seed-scales." Ray, also, in his Synopsis, speaks of this plant.

With regard to its medical properties, the same writer describes it as "hot, bitter, and dry, and sometimes binding." We know not whether this Fern has that peculiarity which Parkinson, two hundred years ago, ascribed to all. "The fume of Fern being burned, driveth away serpents, gnats, and other noisome creatures, that in the fenny countries much molest both strangers and inhabitants that lie in bed in the night time with their faces uncovered." Some consider that Fern, placed on a horse's head, keeps off the flies that tease and sting the poor animal.

Francis calls this species "Aspidium lobatum." Hooker, "Aspidium aculeatum var $a$ lobatum and $b$ intermedium."

We find it growing occasionally in most parts of our district. In Thorncombe it is quite common. Good specimens are to be obtained in the lanes between Avishays and Chard ; between Hawkchurch and Broom ; between Chardstock and Chard, near Galloping close; near Wyke, in the

\footnotetext{
* Filix mas non ramosa pinnulis latis auriculatis spinosis.
} 
parish of Axminster; and at Baker's Meadow, in South Mill Farm at Stockland; in all cases in hedge-banks.

"The Ferns, too, are waving, all statelily here,

With seed-stored fronds thickly laid,

And shedding, when hastily brushed by the deer,

Their light fertile dust o'er the glade." -Twamley.

Plate I, fig. 4.

3. Angular Prickly Fern. Polystichum angulare. Though the scientific agriculturist of the Midland counties may boast of the superior cultivation of his farm ; though their extensive fields, divided by low stone walls, may be better suited for the growth of corn and artificial crops; the botanist and lover of nature's productions may thank the yeomanry of the West for their huge hedge-banks, richly covered with moss and the elegant Fern which we have now to describe. This plant differs from the preceding, as it droops gracefully, like the weeping willow, simple and attractive to behold. Almost every hedge in our valleys presents it to our view. The leaflets near the main stem of the lower pinnæ are very slightly taller than the rest, with a kind of ear (auricle) sticking out more distinctly than in the last species. They are generally not so sharp pointed, but much more rounded or blunt at the higher part. The prickles or bristles are more numerous. The foliage is pale green, and the little leaves have a distinct stalk. The pinnæ, too, are much longer than in the last, and the frond itself is generally far more luxuriant. It varies from one to three or four feet. The little ears or auricles are sometimes divided to the mid-rib, which gives the plant a light and elegant appearance. In such a case the frond becomes tripinnate. There are then, too, very many pinnæ which are distinct, more pointed, lax, neatly and nicely curved, to the admiration of all who have an eye to behold, in every-day objects, the beautiful productions of our great Creator. In other cases, the pinnules are very narrow and linear, and in others (so Protean is its character) very broad, almost of four equal sides, but in an oblique direction, still with a little ear at its base on the side opposite the main rachis. We may lastly mention, that now and 
then, like the brute beasts themselves, the leaflets have two ears, but the inner one is not so large as the outer one. Moore mentions forty three varieties. As a general rule, the plant is softer and more delicate, as well as more shaggy. The frond is never broad, but broader than the other Prickly Fern (Polystichum aculeatum.) In early spring, the young frond makes its appearance with its extremity bent backwards in a most peculiar manner, and then raises upwards again its curled-in shoots. The ends of the young branches are at the same time rolled in, and are by no means unlike a small white silken ball. In young seedling plants the branches are not divided into distinct leaflets, but are merely serrate or pinnatifid. Juvenile botanists must not consider these to be new plants. Other seedling Ferns may also deceive. No plant is mature or perfect until it bears fructification. We may easily distinguish this from the Male Fern, as they often grow near one another, by its different habit and character. This droops and leans towards the earth. That stands nearly erect, and groups around a central axis, in the form of a shuttlecock. The leaflets differ too. In this they are more or less sharp-pointed at one extremity, with bristles at their serratures: in the others, they are blunt, rounded, and oblong. There is a striking peculiarity in some varieties which is not found in many other British Ferns. Have we ever noticed little bulbs arising under the heads of flowers in the Garlics or Onions? These when placed in the ground, would produce a new plant; nay, in a wet season, they germinate of themselves, and we behold a plant growing, as it were, in the air. So also in the Tree Ferns of foreign lands, there are bulbs or buds in the branches, which send their roots downwards, while a new tree rises upwards in majestic grandeur. It is a strange sight to see the roots hanging down from the branches and at last fixing themselves in the ground. In some varieties of the Angular Prickly Fern, we have a miniature representation of this. In the stalk near the earth, or at the junction of the pinnæ and main rachis, there are amongst the chaffy scales, little bulbs or buds, from whence a new plant arises. If we take off these bulbs and put them in a loose soil, we should most successfully cultivate this variety. Our friends at Hawkchurch might try this experiment, as they have what Moore 
would designate Polystichum angulare, var: imbricatum. The leaflets overlap each other, and have four nearly equal sides, with the usual little ear protruding itself in the lower pinnæ. This plant seems to delight in the protection of man. We do not find it run wild with the brake in open downs, commons, and moors. It makes a snug retreat for itself in our Devonshire hedge-banks, and does not object, as many others do, to be improved by cultivation. Though the preceding species is more common throughout the United kingdom, in Devonshire and Wales the contrary is the case. Some have doubted whether there be any essential distinction between these two plants, and when it is borne in mind that there are varieties running one into the other, they are probably identical.

There is no difficulty in making the Prickly Ferns thrive in a fernery. They may be even introduced with success into towns, where smoke and filth prevail. The only thing requisite is to give them a sufficient supply of moisture. They often require the pruning hand, or else no other Fern would be visible. The preceding species is more durable, and bears frost better than the neat and graceful Fern which we have been now describing. The skilful gardener may also, we will not say, deceive, but rather attract and gain admiration by intermixing varieties, and placing side by side the different forms of this almost always elegant Fern.

This species, though generally so common throughout our district, is scarcely to be met with in Otterford and some of the adjoining parishes. That wild elevated district has the Sweet Mountain Fern (Lastrea Montana) in great profusion to supply its place.

This is the last of the Ferns of the neighbourhood, belonging to the family of the Shield-worts (Aspidiea). It is manifest that the name was given to the family because the covers of the fruit are round as a shield.

Family III. The Splenes. Aspleniece.

The English and Classical names have been applied to 
this family, because the plants were supposed to be efficacious in curing diseases of the spleen. Modern practitioners ascribe to them no such virtues. Under this group are contained all Ferns having linear covers not parallel to the side of the leaflet, and opening lengthwise on one side. Many are found growing on rocks and walls, as well as on hedge-banks and in woods. The species indigenous to this country, are generally small evergreen plants, of a rigid texture, with polished stalks. The Lady Ferns are an exception to this rule, and partake in this respect more of the character of the Shield-worts (Aspidiex). There are many exotics of this family. Specimens of these are frequently introduced to adorn our greenhouses.

\section{Genus 1.}

Lady Ferns. Athyria. This genus is a connecting link between the Shield-worts, (Aspidiex) and the Spleens (Aspleniex.) The cover is linear, not in a straight, but curved line. Sometimes it is very slightly crescent-formed, and sometimes as crooked as the circumference of a semicircle. In this case, when the cover is removed, it not unfrequently happens, that the cluster of spores seems to be round. The name Athyrium is of Greek origin, and signifies "without door or inclosure." It was doubtless so called, because the masses of spores burst open the bonds that confine them, and present tokens of their escaping captivity in the fringe, which remains on the margin of the cover. This fringe is best seen through a microscope. The first upper pinnule is nearly of the same size as the next and under one, and herein differs from the Feathered Shield Ferns (Lophodia.)

"Where the copse-wood is the greenest, Where the fountain glistens sheenest, Where the morning dew lies longest, There the Lady Fern is strongest."-Scott.

Plate II, fig. 11.

Lady Fern. Athyrium Filix Femina. Though the Male Fern is to be highly valued for the medicinal properties of 
its roots, the Lady Fern far surpasses it in elegance, and indeed, seems to claim precedence in beauty over every other Fern. Its lovely colour, symmetrical form, and the elegant division of its frond, makes it an object of general attraction. As its name seems to imply, it is very delicate, and requires to be treated tenderly. The Fern collector finds that a warm hand, and a heated room, make it fade, droop, and die. Herein it slightly resembles the Sensitive Fern* of North America. This is said to wither immediately on being touched by man, but to endure the touch of other bodies without injury. Sprengel, a German botanist, asserts, that he repeated the experiment several times with the same effect. The Lady Fern makes its appear. ance in May. At first it is curled together, but when the head (apex) of it is free, it hangs down, and assumes the appearance of a shepherd's crook. There is one cluster of spores on each lobe of the leaflets. The pair of leaflets on each branch nearest the main stem, stands close and parallel to it, pointing upwards and downwards. The breadth of the leaflets varies considerably, sometimes linear, sometimes lance-shaped, and at other times elliptical. They are either notched or cut, pinnatifid, or pinnate. Often there are two or three teeth (not spikes or bristles) at the extremity of each lobe of the leaflets. The leafy part is of a thin texture, so that the veins are easily seen. The veins run alternate, whether on the mid-vein, or on the side-reins. The branches never reach the margin. The higher branch bears fruit. If the cover resembles the circumference of a semi-circle, and has a slit in it, like the Shield Fern (Lastrea), it is not fixed at the slit only, but longitudinally. The stalks are sometimes semi-transparent. They are also very frequently of a reddish cast, never half so long as the frond, with a broad flat base on one side, and semi-circular on the other. The scales are of a dark, blackish colour, and are interspersed over the lower part of the plant. The root is sometimes mistaken for that of the Male Fern. "It has a short perpendicular root-stalk, black externally, with black root fibres; and the tufts or bases of the leaf-stalks, which compose the greater part of it, form a very acute angle with its axis, while those of the Male Fern extend outward at a more open angle."

* Onoclea sensibilis, which Babington says is naturalized near Warrington. 
(Christison.) The trunk or stock often rises above the earth. This Fern will easily be discovered by a person not a botanist, if he earefully notice how extremely fragile it is, and how it withers almost immediately upon being gathered. Its height varies from one to three feet and upwards, and its favorite resort is in moist and warm woods, though we find it in open moors, and under wet hedge-banks.

The Brake (Pteris) was called by the ancients the Female Fern. They do not seem to have noticed this plant. Parkinson perhaps alludes to our species, when he describes two varieties of what was then designated the Female Fern, which he says had not formerly been observed. These he calls "The dented, and sharp pointed Female Ferns." * He adds "They grow rather on moist rocks, and the shaded hills." The name Lady Fern, was not given because the plant was tender, elegant, and beautiful, but because in certain cases it was thought to be most deleterious and injurious, when taken by the female sex. Linnæus, the great Swiss botanist, first assigned the distinctive name of Lady Fern to this plant. $\mathrm{He}$ assuredly showed great taste in giving the appellation to so lovely and charming a child of nature. Hooker and Francis call it Asplenium Filix Femina, and Smith, Aspidium Fil. Fem.

This may be easily cultivated in a loose and light soil. A shady situation should be selected, where there is an abundant supply of moisture. In wet woods, or under a sheltered hedge, with a little stream purling by, we have the finest specimens. Let us only imitate nature, and we, too, shall have luxuriant plants.

\section{Genus 2.}

Spleen-worts. Asplenia. The cover is linear, in a straight line. It is attached, not at a point, but for its whole length. It opens towards the mid-vein, and is not parallel to the sides of the leaflets. These covers are best observed when the plant is young; otherwise their peculiar character is . lost, and they then form round spots on the back of the frond. The mid-vein is generally distinct.

* Filix femina pinnulis dentatis et aculeatis pinnulis. 
"In nature's all instructive book, Where can the eye of reason look, And not some gainful lesson find, To guide and fortify the mind ?"

\section{Plate II, fig. 12.}

1. Maiden-hair Spleenwort. Asplenium Trichomanes. This species is of frequent occurrence throughout Great Britain and Ireland, and grows on rocks, walls, churches, ruins, bridges, and hedge-rows. It is very abundant in this district. Though this is not a very aspiring plant, neither rears its head with crested pride, still, in many of our hedgebanks, where it is thickly matted together, or among the rocks and walls, where it more humbly creeps, it claims the admiration of the lover of nature's productions. It appears much less frequently in the East, than the West of England. It is not only an European plant, but is even found in the far distant regions of Japan, and crossing the Atlantic, shows itself in Canada, and the United States of North America. The plant is from three to ten inches high, rising from a black fibrous root. The stalk is dark brown, or black, and brightly polished. The frond is linear, and simply pinnate. The rachis, at first green, afterwards assumes the sombre hue of the stalk. The leaflets are roundish, eggshaped, blunt at the top, and notched at their margins. The upper surface is dark, dull green, while the under is of a much paler colour. There is scarcely any stalk to the little leaves. Though at first the clusters are quite distinct, while the covers remain, afterwards a dark black mass alone appears, enough to perplex the young collector, if he take such a specimen to determine the species. In the leaflets the side-veins are forked, and there are from six to twelve clusters of fruit on each. 'This Spleen-wort is an evergreen. When the frond begins to decay, the leafy part falls off, but the wiry rachis and stalk remain, a dense and dreary tuft. As the bald head and grey hairs presage the wasting away of the human body, so the accumulation of these leafless stalks betokens the desolating effect of age on this portion of the vegetable world.

The fronds make their appearance in the spring. The spores, invisible to the human eye, are wafted through the 
air, and often settle on some chink in the mortar of an old wall. There a little plant is formed, upward the little curled in frond raises itself, downward the root insinuates, and hastens the destruction of the building upon which it settles. By far the most luxuriant specimens are gathered on the shady hedge-banks. It is found growing in a perfectly wild state, and not an artificial position, such as walls, hedges, \&c., on the cliffs of Beer.

This plant has no pretensions to medicinal virtues, but is generally substituted for the true Maidenhair for making capillaire. Old Gerarde says, "The decoction made in wine, and drunk, helpeth them that are short winded. It helpeth the cough, ripeneth the tough phlegm, and voideth it by spitting. The lie wherein it hath been sodden, or laid to infuse, is good to wash the head, causing the scurf and scales to fall off and hair to grow in places, that are pilled and bare."

Probably it is designated Maiden-hair Spleen-wort, as bearing a humble representation to the true Maiden-hair, Adiantum capillus Veneris. The classical name was given from two Greek words, signifying to luxuriate in hair, because it was considered to "stay the shedding of the hair, and cause it to grow thick."** There is very little difference in the nomenclature of this species.

This Fern is introduced with advantage upon ornamental rock work. As there is great difficulty in extracting the root from walls, cultivators should transplant those growing on hedge-banks. The humble cottager, if he neatly inserts this Spleenwort on banks or rude stones, with others intermixed, may have as beautiful a Fernery as the proudest Peer in the land.

"I'll seek the shaggy fern-clad hill.

And watch 'mid murmurs muttering stern

The seed departing from the Fern :

'Ere wakeful demons can convey,

The wonder-working charm away."-Leyden.

Plate II, fig. 13.

2. Black-stalked Spleenwort. Asplenium adiantum ni-

* Parkinson, Page 1051. 
grum. This also is an ornamental Fern for rock-work and walls. Give it pure air, and a suitable position, and it thrives. In a London atmosphere it dwindles away, neither does it like to be a prisoner in a greenhouse. Like a true Briton, it must have its liberty. It is generally distributed throughout England and Wales, but in some parts it flourishes far more than in others. In the vale of the Axe it luxuriates, and distinguishes itself. Its polished black stalk, and triangular frond, here exceed their usual height. In some places the plant is fifteen inches high, generally, from eight to twelve. The branches are also branched, and triangular. It has a dark glossy green colour, much darker than the prickly angular Fern, (polystichum angulare) and though it droops likewise, is altogether of a more rigid texture. In the walls it is much more stunted than in the hedges. The clusters of fruit are linear, and approach the mid-rib of the leaflet. The branches grow alternate on the mid-stem, and the branchlets are alternate also. The leaflets are sharply serrated at their summit, and wedge-shaped at their base. The root stock is covered with hairy down, some of which reaches up to the lowest part of the frond. The roots themselves are dark brown. The stalk is as long as, or longer than, the leafy part. The lobes, or leaflets, have a mid-vein : the side-veins issue alternately from the midvein, either branched or unbranched. The fruit lies on one or both of these branches of the side-veins. The cover at first is white, a line or two long; soon the clusters of fruit thrust off each their respective cover, and a dark mass alone appears. The fronds grow together in a tuft. Though this is not the Parsley Fern, some fancy it resembles parsley. It is, certainly, much more shining, stiff, and formal. This is not a mere summer resident. When bleak winter comes, and general vegetation ceases, it is visible on our walls and banks. It even retains its greenness and freshness until the end of May, when the child pushes aside the parent, and thin, slight, elegant, rolled-in buds indicate that new fronds are now being formed. The end of autumn comes before the ripe fruit appears and the plant is fully developed. We hardly know where to direct our different friends, as to the best place of procuring thriving and flourishing specimens. They are scattered in tolerable abundance through- 
out the whole district. We should recommend that they be taken from hedge-banks. It is no little satisfaction, that the beauty of nature has not been destroyed here by the miserable stone walls that so disfigure the fields of the midland counties. It would be a sorry sight to see, in this utilitarian age, our noble fences thrown down, nature's arbour demolished, and flint walls alone visible, in three of the loveliest counties of good old Albion.

This Spleenwort is widely distributed throughout Europe, and North and South Africa. The English Fern collectors have also lighted on it in Madeira, and many of the Islands in the Great Atlantic.

The medicinal properties of this Fern were celebrated by older writers. Hoffman considered it as antiscorbutic, and Ray states that it was in use for cough, pleurisy, and asthma. Little is it now valued by modern practitioners.

Gerarde remarks, "That it is called Adiantum, (not wetted)* because the leaf, as Theophrastus saith, is never wet, for it casteth off water that falleth thereon, or being drowned, or covered in water, it remaineth still, as if it were dry, as Pliny likewise writeth." This is not true, though the glossy surface may tend to shake off the liquid more rapidly.

"Before me lay the sea:

Broad, heaving billows murmured carelessly

O'er wave-ribbed sands, with lulling peaceful sound:

While snow-white sea gulls sailed athwart the sky.

The air was motionless, till gentle breeze

Sprang up at sunset; yet huge, lumbering waves

Rolled in from distant storm, wild, musical,

Wave-music."-Symington's Harebell Chimes.

Plate II, fig. 15.

3. Sea Spleenwort. Asplenium marinum. How vast are the treasures of the deep! Not only have we beneath its surface the pearls, the agates, the emeralds, the jacynths, and the crystals clear as glass; we have vast fields of seaweeds and sub-marine plants, which make the ocean appear

* This is the signification of the Greek word Adiantum. 
like a meadow of crimson tint, and the most lovely hue. There is no drapery so rich and fair, no embroidered muslin or silk of so exquisite a texture, no bright and gay festoons so tastefully and elegantly executed, as are to be found beneath the green sea-wave. Those who have leisure to take a survey of the various marine plants, will not only derive profit, but pleasure, and learn the greatness of Him, who is the Maker and Preserver of us all. Some of these seaweeds are so small, that their beauty and admirable workmanship cannot be discerned without the aid of a microscope; some so large, that "They have stems which exceed in length, though not in diameter, the trunks of the tallest forest trees; and others have leaves, that rival in expansion those of the Palm."* There is no Fern that grows beneath the waters. This Fern, the Sea Spleenwort, is only to be found near the sea, with the exception of the lakes of Killarney, in Ireland, and a few other places. In Lancashire and Berwickshire it is recorded to be found some miles inland. On the rocks of the cliffs at Beer, and also at Charlton Bay, it is to be seen in various places. No doubt at Lyme, also, if they were not constantly quarrying out the stone, it would gain a footing. This is a larger plant than the Maidenhair Spleenwort (Asplenium trichomanes.) The frond is strap-shaped, or slightly lance-shaped, and pinnate. The leaflets are dark green, stalked, egg-shaped or oblong, serrate, unequal and wedge-shaped at the base. With each notch, $\uparrow$ not each serrature, there is a line of fructification. The clusters of fruit are rust-coloured, and always separate. The stalk is not nearly so long as that of the preceding species, and is smooth, polished, and reddish brown at the base, if not altogether so. The stalk of the leaflet is generally connected to the rachis, or mid-rib by a wing, so that the frond may be almost considered pinnatifid. The covers are of a light brown colour, and opposite each other. The plants grow in tufts. The root-stocks are black and scaly or downy, and firmly fixed in the fissures and clefts of the rocks. Though the frond is thick and leathery, the veins are clearly apparent. The side-veins fork close to the midvein. The upper branch of the vein bears the fruit. The

\footnotetext{
* Harrey's Manual of British Algæ.
}

$\dagger$ The noteh is deeper than the serratures, and generally contains two serratures. 
leaflets have frequently a little projection, or auricle on the upper side, and on the lower, it appears as if a piece had been cut off. The new fronds begin to arise about midsummer, and the corn harvest is past, and the winter approaches, before they attain to maturity. It is said of the fig, that it blossoms and bears fruit at the same time; so at certain seasons. two years' fronds are in full vigour, the younger only differing in having a lighter colour, and merely a slight development of its fructification. It is from six inches to a foot long, of small size when exposed to the sea blasts, but much finer and more thriving when in a cavern or sheltered situation. We have gathered fronds between Saunders Foot and Tenby in South Wales, eighteen inches long. The Sea Spleenwort has a great tendency to creep and lie prostrate in an inclement situation; hence it is designated by Bauhin, Gerarde, and Ray, "Chamæfilix marina Anglica." (The English Sea Fern creeping on the ground.) It is stated that "The European range of this plant appears limited to the coasts of Spain and France, together with Great Britain. From the Flora Rossica, which embraces the greater part of Europe and Asia, and a large portion of North America, the very name of this Fern is absent."-Newman. It is likewise met with in Barbary, the Canary Islands, and the West Indies. Hooker also adds "I possess specimens from New Brunswick, Nova Scotia in British North America, and from Rio Grande do Sut, in South Brazil.

Gray states that a mucilaginous extract of it is useful in severe burns and scalds. There would be some difficulty in procuring a sufficient number of fronds to try the experiment.

This is no easy plant to cultivate, for it scarcely ever grows among rockwort, unless it exhales the pure sea air. As it is found growing in some few places at a distance from the sea, and as some few cultivators have succeeded, it is recommended to plant it on rockwort, with sand or peat intermixed, with a southern aspect, screened both from frost and sun. Great care should be taken not to break the roots, when they are extracted from the rocks. It will certainly thrive in a hot house or under a glass. 
"When the fern is as high as a spoon,

You may sleep an hour at noon:

When the fern is as high as a table,

You may sleep as long as you are able."

\section{Plate II, fig. 14.}

4. Wall Rue Spleenwort. Asplenium ruta muraria. Newman considers this as belonging to a distinct genus, Amesium, because the ultimate subdivisons are without a distinct mid-vein. This plant no doubt received its name from its resemblance to rue. It is to be found on almost every ruin and old wall, and "like our half-domesticated birds, the sparrow, the swallow, and the martin, seems to have deserted its native wilds, and to have taken its residence among the habitations of men."* Though growing in the moist clefts of rocks, and even on their perpendicular faces, it is much more frequently found on decayed walls. The frond is bipinnate (doubly divided) at the base, and pinnate (simply divided) at the tip. The leaflets are diamond-shaped, oblong, or eggshaped, with the upper part toothed. The root is dark brown, whence many fronds arise thickly crowded together. The plant is dark green, rather of a blueish cast, and the leaflets are stalked. There is no distinct mid-vein to the upper leaflets, but a series of veins arise, which are sometimes branched. As many teeth or notches as there are on the tips of the leaves, so many, for the most part, are the veins or their branches. The clusters of fruit are from two to five. The covers are jagged or uneven at their margins. The leafy part is triangular, and the branches often consist of three leaflets. The stalks are wiry, and, at the base only, dark brown or black. The roots are dark and fibrous, penetrating deep into the mortar, and difficult to be extracted. It is especially fond of brick walls. The favourite part of the wall, whether stone or brick, on which it perches, is just under the coping. There we find the diamond leaves and spider's cobwebs fondly embracing each other. The young botanist, if he wishes to discover the genus to which this Fern and some others belong, must be careful not to wait until the fructification is too far advanced. If he does so, he will 
find to his cost nothing but a dark mass of fruit behind the leaflet, and the cover, which is linear (a straight line*) the characteristic of a Spleenwort, vanished out of sight. Herein this plant is different from the preceding, in which one line of fruit never crowds upon its neighbour.

This is not only a common plant in England, but is widely distributed throughout all Europe, and temperate Asia. It has also been found in certain parts of North America, in North and South Africa, and Northern India. In the West of England it grows far more abundantly than in the East.

"Wall rue," says Gerarde, "is good for them that have a cough, that be short winded, and that be troubled with stitches and pain in their sides." "It is commended against ruptures in young children, and some affirm it to be excellent good, if the powder thereof be taken continually for forty days together." Some modern writers have stated that it is demulcent and diuretic.

There is little difference as to the classical name given to this plant. Newman, as stated above, places it under a different genus, and designates it Amesium ruta muraria. Parkinson states, that it is the white Maidenhair of Theophrastus, and names it Ruta muraria or Salvia vitæ. In his explanation of the word salvia, he remarks that that word was given to a plant, "because it makes men safe (salvos) and sound in health, and the Latin versifier from hence took his occasion to say,

"Cur moritur homo, cum salvia crescit in horto ?"

Why does a man die, when the salvia grows in the garden?

Whosoever wishes to have a perfect collection of the "Ferns of the Axe," and therefore desires to cultivate this plant, must be careful, as has been so often suggested in the case of others, when he transplants it, not to break the roots. Let him imitate nature, make an artificial coping at one part of the rockery, put old mortar and brick close to the coping, and there place the Wall rue Spleenwort.

Genus 3.

Scaly Spleenworts. Ceterach. Clusters linear, straight. Covers upright, generally on the uppermost branch of side-

* This is true in all but the Lady Ferns, where it is a curved line. 
veins. Side-veins united. Back of frond covered with chaffy scales. This genus is remarkable for the side-veins not remaining distinct from each other, and for the chaffy scales on the back.

"Great Dioscorides relates,

If pluckt in open weather,

This herb a swollen spleen abates,

Nay, if for forty days, saith he,

You drink it steep'd in vinaigré,

Removes it altogether.

Ye spiteful souls, its virtues try,

One thing well nigh I had forgot,

That when the vinegar you buy,

In using, make it boiling hot."

Quincy,

Pharmacopæa Officinalis,

10th Edition,

MDCCXXXvi.

Plate I, fig. 16.

Scaly Spleenwort. Ceterach Officinats MThough this is thickly scattered on almost every old wall in the midland and northern parts of the County of Somerset, it by no means luxuriates in the district of the Axe. It is rather partial to lime stone. The frond is deeply divided, but not sufficiently to make distinct leaflets. The divisions or lobes are bluntly rounded, and not in the least notched. Many fronds arise from the roots, three to five inches long. When the first buds begin to appear, they assume a glossy white colour. The lower surface is covered with thick shining scales. No other Fern growing in the neighbourhood in any way resembles it. The scales at first are white, afterwards brown, which, when seen under a microscope, appear to be beautifully net-worked. The lobes are alternate, rarely opposite. They turn upward when old, and expose their fructification. The fruit only appears when the fronds are aged, and then bursts through the scales in oblong, transverse masses. It seems questionable whether there be any real cover to the clusters of spores. Hooker says that there is - that Ceterach is now found to possess a narrow involucre (cover) like that of Spleenwort (Asple- 
nium.) All seem to allow that there is a kind of ridge as thin as the finest muslin or gauze, which is to be found close to the veins on which the clusters lie. Nature does not require the same perfect covering for the bags of spores, as the chaffy scales perform the same part. The fronds grow in tufts, and are thick and fleshy. Most Ferns, if not perfectly transparent, are not what we should style opaque, as is the case with this. The stalk is short and scaly. The roots, though not long, force their way into the mortar or crevices of the rocks, to which they firmly adhere. As the plant generally grows on lime-stone, we are surprised that it has not been found at Charmouth or Lyme. Being rather fleshy, it is difficult to discover the veins. The mid-vein rises from the lower corner and bends a winding course to the middle of the highest part of the lobe. The side-veins rise alternately, and fork once or twice successively, and intersect the branches of the other side-veins. The clusters are always on the highest branch of each, opening towards the top of the leaflet or division, except in the case of the lowest branch of the lowest side-vein, which often has fruit also : then the covers of the clusters open towards the mid-rib of the frond. If other English Ferns were found in a fossilized state, it is very improbable that this would be discovered. Much water causes it to decay. It is generally found on a dry rock or wall. Larger specimens are, however, gathered in places not exposed to the mid-day sun. The upper surface of the plant is of a dull green colour, with a shade of yellow. In its young state, it is curious to see how the alternate divisions of the curled-in fronds, like the teeth of a rat gin, exactly fit into one another.

This is rather a scarce Fern, especially in the Devonshire part of the district, and here only found growing on walls. It is most abundant at Wooden (vulg. Wootton) farm, in the parish of Chardstock, and there, not on the limestone rocks, but only on the walls. It is also met with at Chard, Colyton, Uplyme church wall, and other localities which will be hereafter enumerated.

In olden times this was in great repute for diseases of the spleen. Dioscorides, mentioned in the verses at the head of this article, was not the only person to recommend it. Parkinson states, "that the herb and root being boiled and 
taken, helpeth all melancholicke diseases, and the lye that is made of the ashes thereof, being drunk for some time together, helpeth splenetic persons." Vitruvius* says, " that the swine in Candy (Crete) where it grew, by feeding thereon, were found to be without spleens, when, as others that did not eat thereof, had them as the rest." + Hence the name of Spleenwort, Asplenium, from $a$, not, and splen, spleen. This was also used as a bait for cod fishing.

With the ancients, this was the true Asplenium. The moderns generally make Ceterach a distinct genus. Smith called it Scolopendrium ceterach. Newman names it Notolepeum ceterach. Hooker, Asplenium ceterach. Moore, Francis, and Babington, Ceterach Officinarum. The word is of Arabian origin.

The scaly Spleenwort has not been found in the North of Europe or Asia, but is generally distributed throughout the Midland and Southern parts of Europe, and a portion of Asia, and in the North of Africa. Somerset is one of its favourite English counties, and it grows at Somerton, and other towns where the blue lias prevails in the greatest profusion. It is said to be an evergreen, but this is not true, for we have in the winter season searched the walls of the town mentioned, most diligently, and not found a single plant.

Some little pains must be taken to ensure success in the cultivation of this species. If in a rockery, old mortar should be placed among the stones where it is to be planted: if in a greenhouse, there should be a mixture of peat or loam, limestone, and old mortar. Let there be no stagnant water, nor a very great supply of fresh water. If possible, a southern aspect should be avoided.

\section{Genus 4.}

Hart's-tongues. Scolopendria. Clusters and covers in pairs, one seated on the lower, and the other on the upper branch of each side-vein, and opening to face each other. For examining plants of this genus, neither should too young plants be selected, for then the two covers fold over

* We presume that this is the great Architect who flourished about 50 B.C. † Parkinson, Page 1046. 
each other, nor should the plants be too old, for then the covers disappear, and the two lines of fructification are in one confused mass. In the intermediate state, the two covers are apparent to the natural eye, Plate II, fig. 17. By making a transverse section of the fructification when young, and by microscopical inspection, it will be observed that the two covers fold over each other, and that there are also two masses of fruit. This is a genus of which only a few species have been found throughout the whole world.

\section{"This herb, if Pliny saith aright, Doth cure the Scolopendra's bite: \\ From this its name is taken. \\ But, like the famed Mandragora, \\ Its use and name have passed away \\ From the Materia Medica- \\ Time hath the fable shaken. \\ Truth's dicta time doth never shake- \\ Thus when you observation take \\ Of its elongate form and make, \\ The Hart's-tongue doth appear \\ And when you note its sporules wide \\ Arranged upon the under side, \\ Like legs to centipede supplied,}

The Scolopendra's clear."-Gilbertus Cambrensis.

Epigrams, No. 27.

\section{Plate II, fig. 17.}

Hart's-tongue. Scolopendrium vulgare. This Fern is very abundant in this district, and grows profusely on neglected walls and hedge-banks, as well as in old wells. Those growing on walls, and in exposed situations, are of a yellowish colour, much more stunted, stiff, and leathery, while those in damp and shady situations are of a darker and more polished verdure, drooping and spreading most gracefully in lengthened and elegant tufts. This is a very handsome Fern. In the summer months, whether in a wild or cultivated state, what a lovely contrast is presented when the rich, glossy foliage of the Hart's-tongue is blended with the soft, lax, drooping Prickly Fern, or with the light, elegant, finely and neatly divided Lady Fern. It is, however, quite 


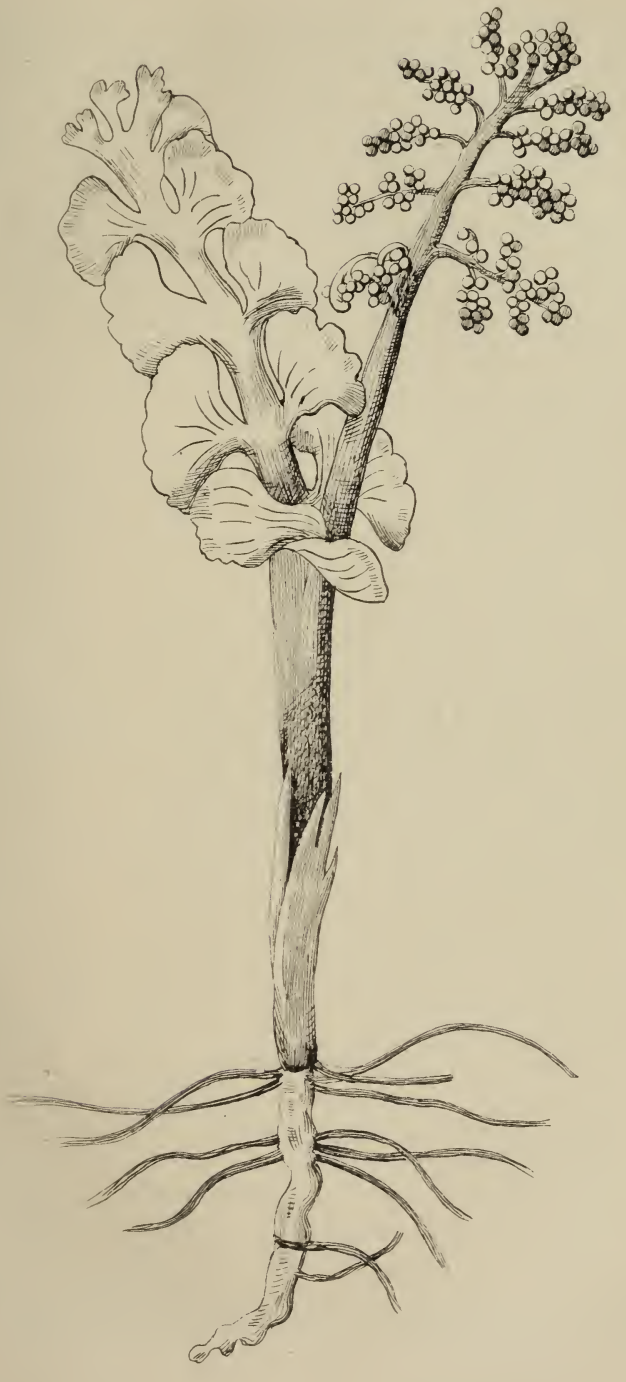



different from any other British species. It is universally distributed throughout the British Isles, and is also found in every Country of Europe, but sparingly towards the North. In North America it is said to establish itself only in New York. No account has yet been given of its growing in Africa, Asia, or South America. In its ordinary form it is strap-shaped, quite undivided at the edges, pointed at the tip, and heart-shaped at the base. The stalk averages about a third the length of the.frond, is dark brown at the base, and has lance-shaped or hairy scales scattered over its surface. The fronds vary much in length. In favourable positions they are more than a foot long. With regard to the covers of this Fern, it cannot fail to strike a man of the dullest apprehension, with what consummate skill and exquisite proportion they are adjusted. In every instance the lowest branch of the upper side-vein, and the highest of the next lowest, are placed exactly at such a distance as to admit of the double line of fruit and the pair of covers. The parts are so nicely arranged, so well balanced, that they are not a hair-breadth nearer or further apart than is requisite for the organs of fructification. There is no need of a glass to aid in making these observations. If we merely hold up the leaf to the light, and direct our vision to the parts, we shall not fail to behold this beautiful organization. The covers are at first white, afterwards rusty brown. When the clusters become old and have thrown aside the veil, they form one long confused black mass. The fructification scarcely ever appears in the lowest part of the frond. The roots are black, stout, and very long. The root-stock is blackish, tufted, scaly, spherical, or sometimes like a carrot, spindleshaped. The leaves have a strong and thick mid-rib, it can hardly be called a rachis, much less a mid-vein, from which the side-veins start, and afterwards fork twice or thrice without reaching the extremity. Moore says, "that they terminate just within the edge in a club-shaped apex." In the month of April we may look out for the young frond, which appears perfectly upright, with its summit curiously rolled or coiled together, as is the case with most Ferns. As it grows older, it humbles itself and becomes horizontal. At last, as if the trials of the world were too much for it, it hangs down its head and is quite pendulous. It comes to 
perfection in September, and during the winter months, when almost all the green foliage is gone, the eye is refreshed by beholding this plant and the Common Polypody adorning our hedge-banks in great luxuriance. It alone appears shabby and shows symptoms of decay, when the spring is returning, and the wild violets, harebells, and primroses are adorning our hedges. When the spring is still more advanced, and the herbage is thickly set together, the young, erect, light green fronds, with their curled-in summits, appear through the bushes. This may not be noticed by the heedless passer by, but the naturalist cannot take his walks abroad without observing a plant of so beautiful and lovely a character, even in its earliest stage of existence.

The Hart's-tongue, when bruised, emits a nauseous smell. It is the Phyllitis of Ray and all older botanists. It was formerly considered very valuable for medicinal purposes. Dioscorides asserts, "that when drunk in wine, it is a remedy against serpents' bites or stings." Ray mentions it "as a good medicine in convulsive disorders." Older writers ascribe to it the power, not only of relieving the spleen and liver, but "all other griefes proceeding of stoppings whatsoever." We learn from the Flore Francaise, that it is used in France as an astringent in cases of diarrhœa and hœmorrhage. Our older English physicians ascribe to it a similar healing power. At the present day it is used in country parishes for cuts and sores, burns and scalds.

There is little difference now in the classical name given to this Fern. Newman calls it Phyllitis Scolopendrium. Linnæus first altered it from Phyllitis to Asplenium Scolopendrium, and Withering adopted the same name. All others designate it now Scolopendrium vulgare. The common name given to it in France is "Langue de cerfe," Hart's-tongue.

Scolopendra, from whence Scolopendrium is derived, is the scientific name of a Millipede, or Thousand-legs, an insect with which most persons are very well acquainted. The Fern was given this name because some fancied that the covers and fructification of this plant resembled these insects.

Here there is no difficulty as to cultivation. As generally 
the finest plants are found in moist, shady hedge-banks, the same result may be expected, if due regard be paid to the course which nature points out. If placed in rich soil in a greenhouse, varieties will be produced, and the plant will depart from its ordinary form.

\section{Family IV. Matdenworts. Adiantece.}

Covers linear, either parallel to the edge of the leaflets or apparently formed by their bent-back edges. This family contains the true Maidenhair, Adiantum capillus Veneris, which is not one of the Ferns of the Axe.

\section{Genus 1.}

Hard Ferns. Blechna. The covers are parallel to the edge of the leaflets. The bags of spores lie in a long straight line between the mid-rib or mid-vein, and a vein somewhat parallel to the mid-vein. This vein is connected with the mid-vein by transverse lines. This genus is distinguished from the rest of the family, in not having the edge of the leaflet bent back when fructification is formed. Thirty-one species of this genus have been discovered, though we have only one in Great Britain.

"Oh, mickle is the powerful grace, that lies

In plants, herbs, stones and their true qualities:

Nor nought so vile, that on the earth doth live,

But to the earth some special good doth give:

Nor aught so good, but strained from that fair use

Revolts from true birth, stumbling on abuse."

Shakespeare.-Romeo and Juliet.

\section{Plate I, fig. 18.}

Northern Hard Fern. Blechnum Boreale. This plant has both a barren and a fruit-bearing frond. It prefers the north side of hills, and hence the name. It appears to the eye much like a two-edged comb, the teeth of which are much wider and coarser in the barren than the fertile frond. The teeth also instead of being uniform in width, taper at 
the extremities. The fertile fronds are nearly twice as high as the barren ones, and vary from twelve to eighteen inches. The leaflets are a little wider towards the base, and the back part of those which are fertile is covered with fruit. These latter also become more and more remote from each other as they approach nearer the base, and in both cases the leaflets are alternate. The stalks, too, vary. In the one they are long, with a few rudimentary teeth interspersed, smooth, glossy, dark brown, having a few fine scales; in the other they are short, greenish brown, and more densely covered with scales. A tuft of these fronds is spread in a circular form. The outer ring consists of the barren, and the inner of the fertile fronds. The latter die before winter sets in, while the former remain green and fresh until the early spring. It might almost be imagined that there are here two distinct Ferns, as one kind appears so much taller, more graceful, and not ashamed to hold up its head; while the other is nearly prostrate, not so finely divided, and though of a bright green colour, still seems to indicate its inferiority. At first the covers are white, in a long uninterrupted line, lying upon a longitudinal vein, which is situated about midway between the mid-vein and the margin. These afterwards bend back, open towards the mid-vein, and burst asunder in patches. This is much more clearly seen, if we select for inspection a plant sparingly fruited, and having the widest pinnules that we can find fruit-bearing. When the fructification is mature, as it is in August or September, the covers become light brown and ragged. The side-veins of the pinnules of the barren plants fork between the midvein and the edge, and never unite, but end in a knob. The mid-veins are generally transparent. The root is black and wiry: the root stock tufted and downy. Though the plant resembles a two-edged comb, it would not be a useful comb, as the leaflets are generally curved like a hook, especially in the fruit-bearing fronds. The Hard Fern makes its appearance in May, and sheds its seed (spores) in September, when the fertile fronds disappear, while the barren ones remain through the winter.

This plant is scarcely ever met with in a chalk soil. It prefers gravel, or even stiff clay, on which this is almost the only Fern that thrives. It is ornamental for rock work, and 
should be so planted as to face the North, for which aspect it shows a decided preference. It delights more in the damp shades and chilling blasts of Boreas, than it does in the bright sunshine, which covers the rich vales of the Axe and its tributaries with a golden yellow, and a luxuriant sweet green verdure. Let not this child of nature be despised because he loves to dwell in the bleaker and more chilling regions of our delightful neighbourhood.

Parkinson furnishes us with an accurate description of this Fern. He calls it the Smaller Rough Spleenwort. Lonchitis aspera minor. "The divided leaves" of the barren frond "are each separated from others, but not fully to the middle rib. In the middle of those outer leaves rise up other bigger and thicker stalks of the narrower leaves, like unto them, but fully separated and so finely dented about the edges, that they seem curled with brownish spots or scales on the backs of them, as in other Ferns." He also adds that, it is called by "Cordus and Thalius, Struthiopteris, as if you would say the Ostrich Fern for the fine wings of the middle leaves." "This" he also adds, "is called the Foxen Fern by many persons of this land." "The dried leaves taken in vinegar is held to be good to dissolve the hardness of the spleen, and the green leaves to be singular good for wounds, and to keep them from inflammation."

Various names lave been assigned to the "Hard Fern" by different authors. The very old writers called it Lonchitis aspera minor. The Lesser Rough Spearwort. Linnæus changed it to Osmunda Spicant. Withering, Newman, and Moore, to Blechnum Spicant. Francis, Hooker, and Babington, Blechnum Boreale, (Northern Blechnum,) which seems the preferable name, as it generally grows in a northern aspect. Blechnum is a Greek word used by Dioscorides for an unknown species of Fern.

All Europe claims it for its own. It has been found in North Africa, and probably North America. In some parts of our neighbourhood, the lower parts of the hedge-banks are quite matted with the barren fronds, and it requires some little strength to pull up the black, tough, and wiry roots of this plant with its tufted and hairy root stock. 


\section{Genus 2.}

Brake. Pteris. Bags of spores in a long straight line covered by the bent-back unbroken edge of the leaflets. This differs from the Hard Ferns, Blechna, in having the edge bent back to form a covering, and from the Maidenworts, Adianta, (none of which grow in this district) in having the bent-back edges in an unbroken line. The fertile leaflets of this genus have a thin, white, membranous edge, which is the part of the leaf that bends back and forms a cover of the clusters of fruit. These clusters are seated on the extremity of the green part. "An inner cover is also present in ours and some other species, which many botanists consider a necessary character of a Pteris, and that its absence or presence might serve to divide the genus into two."-Francis. There are many foreign Ferns that belong to this genus.

"The heath this night must be my bed, The bracken curtain for my head, My lullaby the warder's tread, Far, far from love and thee, Mary ;

To-morrow eve, more stilly laid, My couch may be my bloody plaid, My vesper song, thy wail, sweet maid!

It will not waken me, Mary."

Scott's Lady of the Lake, Canto III.

Plate II, fig. 19.

Brake or Bracken. Pteris aquilina. This Fern abounds on all our Commons and uncultivated ground. It affords the agriculturist considerable trouble to exterminate it, in consequence of its creeping, under-ground stem. It is said that Linnæus, the great botanist, came from Sweden to England to see the Furze, among which the Brake is constantly intermingled. When the great naturalist beheld its bright yellow flowers covering acres of ground, he is described as falling down on his knees in humble adoration. Neither is this Fern destitute of beauty and elegance, and together with the Flowering Fern, Osmunda Regalis, resembles the Tree Ferns of tropical climes more than any other. 
It diminishes the barren aspect of our heath-fields and downs. Brake is so common that it hardly needs any description of its form. Suffice it to say, that it stands up like a tree with branches on each side, which are again and again divided into other branches. The leaflets are linear, the upper ones generally without, and the lower ones with deep notches on their edges. The terminal leaflet of the toothed pinnæ has the appearance of a dagger. When the frond first begins to unfold itself, the stalk divides into three branches, and not only is the highest point of each branch rolled-in, but also the leaflets at their extremities. One of these three branches rises upwards, while the others spread right and left. The highest again and again branches according to the luxuriance of the plant. The branchlets of the branches are often again branched, and thus it becomes tripinnate. The leaflets vary. Sometimes they are toothed or pinnatifid, and at other times not in the least degree divided on their edges. They are also connected to the mid-rib, not by the stalk, but by their whole base. Hence they assume the form of a wedge. They are opposite below, alternate above. The veins are transparent. In the mid-vein are some brighter spots which appear like little stars, from whence issue the side-veins, which fork twice or even more in the lower part, and once in the higher part of the leaflet, and then reach the green margin. On this margin is a vein running lengthways, by which the others are connected together. The fructification is attached to this. From the upper surface edge of the green part proceeds a thin white cover, and from the lower surface edge another white similar extension, on which the clusters of spores lie. What a beautiful provision is here made for the propagation of the plant! The leaf must alter its colour and become thin and tender, that it may cradle its child with every care. The branches or pinnæ of Brake are opposite. The stalk at first is downy, afterwards smooth, having its lower part and what is underground of a dark brown colour. It is quite as long as the branched part or frond. These mainstalks have sometimes a sharp edge, and wound the hand severely if plucked incautiously. There is a creeping rootstock (rhizome,) which is brown or blackish, about the thickness of a man's little finger. From hence 
the plant rises up at intervals, as in the case of the Polypody. In the downs it is comparatively a stunted plant, but in the wet woods and shady places, it not unfrequently reaches the height of nine or ten feet, a rery graceful and elegant object. What with its wide-spread branches, and light green colour, and feathery foliage, it surely deserves a place among the beautiful works of nature. The Bracken is very susceptible of cold. In autumn, a severe frost soon turns it to a deep brown colour, and makes it wither. In the spring, a whole crop is cut down, like the potatoes, by the sharp and piercing north easterly wind.

Brake is to be found in every country in Europe, and it is a question whether the species of Pteris found in Russia, Africa, New Zealand, and the Sandwich Islands, is not identically the same. Great indeed is the variation of form. But this may be ascribed to the difference of soil, clime, and position. Hooker says that the edible Fern root* of New Zealand is a mere variety of our Common Brake. That used to be the favourite food of the New Zealanders, and was celebrated in song. The young women in laying before travellers baskets of cooked Fern-root, chalnted, "What shall be our food? Shall shell-fish and Fern-root? That is the root of the earth: that is the food to satisfy a man." Dr. Clarke shows that the root, if properly prepared, would be preferable to spinach, and have a more beneficial effect on the digestive organs. It is however found, that though life may be preserved, men would not gain much animal strength. Pigs are fed upon the roots boiled down to a mucilaginous mass. The root, when cut obliquely, presents a kind of representation of the imperial eagle, and hence the name of Pteris Aquilina, or Eagle Brake. Young per. sons, in cutting the same roots, observe a fanciful letter of the alphabet, which they take for the initial of their lady-fair. Nay, there is a great similitude to an oak tree, as appears from the woodcut annexed, made from a drawing of a section of the brake. Dr. Johnson, in his "Terra Landisfarnensis" says, "The mark is a'so

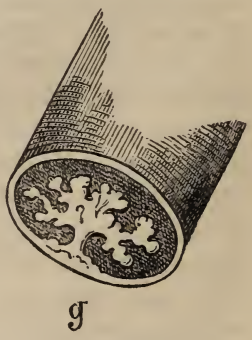

\footnotetext{
* Pteris esculenta.
} 
compared to the impression of the De'il's foot." Common as this Fern is, and varying as it does from most others in not confining itself to hedge-banks, or to the retreat of damp shady woods, it is possessed of some great and important virtues, and next to the Male Fern, is the most valuable of all. A tolerably pure alkali may be obtained from this plant. In many parts of England, the ashes mixed with water are formed into balls, which are afterwards heated in the fire, and used to make lye for scouring linen. Lightfoot says, "It is an excellent manure for potatoes, and if buried beneath their roots, never fails to produce a good crop." Where coal is scarce, it is used for heating ovens and for burning limestone, for it yields a very intense heat. It is so astringent, that it is sold in many places abroad for dressing chamois and leather. It is an excellent litter for horses and cows, and in Invernesshire, the poorer classes thatch the tops of their houses with the leaves, which form a durable thatch. Newman observes, "It would appear that formerly it was in use in England for the same purpose, for by a statute for regulating the price of labour in England, dated 1349, being the twenty-third year of Edward III, we find it enacted that every tyler or coverer with straw or fern shall receive 3d. per day, and their servants or knaves $2 \mathrm{~d}$., and their boys $1 \frac{1}{2} \mathrm{~d}$. per day." It is also said that a decoction of the ashes of this and some other Ferns stimulates the growth of hair, and hence they have been called capillary plants. This plant is not unknown to the Scottish poet,

"Far dearer to me yon lone glen o'green Brechan,

Wi' the burn stealing under the lang yellow broom."

As in some places the plant attains a considerable height, it offers a bracken curtain to the deer for his evening couch, and has concealed many an armed Highlander in days of old. Sir Walter Scott, in his "Lady of the Lake," describes Roderic Dhu's men, as springing from the Bracken at the sound of the whistle of their chieftain.

\footnotetext{
"On right, on left, above, below, Sprang up at once the lurking foe, From shingles grey their lances start, The bracken bush sends forth the dart."
} Scott's Lady of the Lake, Canto V. 
This is the Female Fern ( $\theta \eta \lambda v \pi \tau \epsilon \rho s)$ of Theophrastus and Dioscorides. It had this appellation because it was considered so injurious to the female sex, that, if they walked on it,* much less took it inwardly, it would be attended with very bad effects. Linnæus first transferred the name to another species. Pteris aquilina is the designation now adopted by all modern writers except Newman, who calls it Eupteris aquilina.

A description has now been given of twenty species of Ferns, all Ferns of the Axe. In the subsequent article an attempt will be made to point out some leading varieties of these interesting plants. An ancient Roman poet has said,

"Neglectis urenda filix innascitur agris.-Horace."

The fern grows to be burnt in neglected fields.

Sorry should we be if such were to be the fate of all the Ferns of the Axe and its tributaries. We view them as one of our greatest ornaments. Our woods, our hedgebanks, and our shady lanes derive much of their beauty trom these elegant plants. Not only in the spring, but throughout the greatest part of the year, they add a softness and grace to the scenery, and draw the contemplative mind to admire the works of our great Creator. Surely the man must be devoid of taste who has no eyes to admire not only the humbler of these plants, which grow among our walls, and bridges, and ruins, but also the Lady Ferns, and the Royal Flowering Ferns, which so abundantly adorn the neighbourhood of the Axe. Beautiful as the river and its branches are, which wind their course through our lovely vales; magnificent as our views are, which exhibit Dartmoor on the one band, and the Somersetshire hills on the other; interesting, too, as this country is in an historical point of view, whether we turn to the Roman or to the ancient British remains, or to the troublous times of the Commonwealth; we also beg to contend that the lover of nature may likewise find a rich treat, if he pay attention to the flowers, and shrubs, and ferns which grow in such profusion in this locality. In the metropolis we have artificial grottoes and arbours, and rockwort covered with various plants, on which

* Parkinson says this is a fable. 
the water is made to bubble and trickle down. Here we have the glorious reality. Here we have the Great Artist Himself at work. Behold our shady lanes covered with branches of trees and woodbines intermixed-nature's magnificent arbour. Mark the rockwort close to our streamlets, covered with mosses, lichens, and ferns, down which the water splashes and gurgles so sweetly and so grandly. May we not conclude by saying -

"Nature boon

Poured forth profuse on hill and dale and plain Both where the morning sun first warmly smote The open field and where the unpierced shade Imbrowned the noontide hours." 


\section{VARIETIES.}

As so much attention has lately been directed to the varieties of Ferns, it seems desirable that some of these should be noticed. Our readers must not be disappointed if they find unusual appearances not explained. There is scarcely any thing in the regetable world that is always uniform. Blight, insects, poverty or richness of soil, great drought or rain, produce marvellous changes in particular plants. These things are so local, and confined to certain seasons, that it would be impossible to describe what may happen. All that will be attempted is to mention some leading and striking varieties or monstrosities.

Great is the difference between a variety and a species. Man is a species of the order Being. A white, black, or copper-coloured man is a variety. The species man invariably differs from all other earthly beings in the possession of reason. There is no such invariable difference between the varieties of men. The white man gradually becomes darker and darker as he approaches the tropics, until he becomes the sable African or Indian. Just so with regard to the vegetable creation. One species differs from another under every circumstance and aspect. Not so the varieties. These so gradually merge one into another, that the line of demarcation cannot be distinctly seen. If we see the extreme varieties only, we should pronounce them distinct species, but when we see how they shade one into the other, we cannot hesitate to pronounce that they are one and the same species. Besides varieties, monstrosities also occur. In 2 Samuel, xxi. 20, mention is made of a man "that had on every hand six fingers, and on every foot six toes." This we should consider an abnormal or unnatural appearance 
of man. Just so our Ferns. From some particular position or injury, they assume unusual forms, which are commonly denominated monstrosities. The varieties generally occur, to a considerable extent, in a particular locality. Only single instances of monstrosities are found, and those only in one plant, and sometimes merely in part of a plant. With regard to varieties, we may also add that they continue constant in the same form as long as they live. If, however, their spores (seeds) be thrown into the earth, especially when placed in a situation where the contrary form prevails, then the plant often becomes changed to its original type. How are those choice apples prized which are placed on the table for the dessert, and for which the gardeners charge an exorbitant price! Yet the pips or seeds of these often produce a crab tree, whose fruit is most despicable, hardly fit to make the sourest vinegar.

We will now proceed to describe some of these unusual appearances, or varieties of the species of Fern.

\section{AdDer's Tongue. Ophioglossum vulgatum.}

See page 11.

The fronds are sometimes furnished with two, three, or four spikes. These have been found in several parts of the district.

\section{Comirom Pourpody. Polypodium vulgare.}

See page 18.

1. Serrated Common Polypody. Serratum. This merely differs from the ordinary form in having the edges serrated or notched.

2. Forked Common Polypody. Bifidum. Some of the lobes are forked at their ends, especially at the lower part of the frond. The mid-vein separates into each fork, and if it be fertile, the clusters of fruit are on each side of the separated mid-vein. This variety is found between Hawkchurch village and Broom, and near Weycroft turnpike gate and Smallridge, both in the parish of Axminster, and at Hobknap in the parish of Musbury on hedge-banks by the road-side. 
3. Auricled Common Polypody. Auritum. At the base of the segments or lobes on the upper side near the mid-vein, is a little round lobe or auricle. In our plants we do not find it on every segment, but chiefly on the lower ones. This has been gathered in Dalwood parish near Sunnyland, and on a hedge-bank of a wood in Musbury parish, close to Bullmore in Axmouth parish.

4. Sharp-pointed Common Polypody. Acutum. The lobes gradually taper to a point. At the base they are rather broader than in the common form. If a lobe is forked, each fork narrows gradually in the same way. Sometimes the lobes are serrulate, (i.e. very slightly serrated.) This has been gathered at Dalwood.

5. Many-formed Common Polypody. Multiforme. A single plant of this variety has been discovered on the hedgebank of a Common in Northleigh parish. This is divided into two branches or branched lobes at the summit, with an intermediate undivided lobe. All the lobes narrow gradually to an acute point. The branched lobes have a semicircular enlargement near their base, and seem to be cut, as it were, by a pair of scissors from the middle lobe. One of the lowest lobes of this Polypody is forked at the extremity. All the leaflets are obscurely serrated at distant intervals, and in some spots deeply notched. Other plants are sometimes branched near the base or middle of the frond. Sometimes, too, the mid-vein runs beyond the lobes. There is no regularity in the formation of this variety.

\section{MaLe Fern. Lastrea Filix mas.}

See page 23.

1. Deep-cut Male Fern. Incisa, Moore. Affinis, Newman. The stalk is about a fourth the length of the frond, which is large, broad, and branched. The basal leaflet of the branches or pinnæ have a narrow attachment and no stalk. Most of the other leaflets are decurrent and run into the stem. There is generally a slight auricle at the bottom of each leaflet. The leaflets have less width, are longer, more deeply cut, and more separated from each other than in the com- 
mon form. The lower leaflets of a pinna have from three to five teeth. The branches of the veins, too, are more numerous. While the clusters of fruit in the regular plant occupy only the lower half of the leaf near the mid-vein, these reach much nearer its summit and are arranged in a single row. The scales are yellowish red, and do not so thickly cover the stalk. The foliage is, when mature, generally dark green, and conspicuous. The rachis and stalk have occasionally a polished purple-brown colour. This is a robust, large, handsome Fern, not uncommon in the neighbourhood, outvying the standard form in its usual aspect. It, however, assumes the autumnal bue very early, and is not an evergreen to adorn our woods and hedge-banks during the dreary season of winter.

2. Chaffy Male Fern. Paleacea, Moore. Borreri, Newman. As this variety was first noticed in Devonshire, it is not surprising that it is found in this neighbourhood. Its rich, shining, golden brown scales, and lofty yellow-green fronds, growing densely and compactly in a shuttle-cock form within our beautiful woods, make it an especial object of admiration. Hooker considers it a good representative of the normal or most perfect form of the species. It seems to be Don's Aspidium paleaceum of Nepaul, common enough in other parts of India and elsewhere. Most certainly it is a most striking object, and should not be passed by without a minute description. The scales, its leading characteristic, are generally bright golden brown, most thickly crowded together, not only on the stalk and root-stock, but also on the mid-stem of the frond, and of the pinnæ likewise, giving the plant a peculiarly beautiful hue. The lowermost scales are broadly lance-shaped; as they rise upward they become narrower and narrower, and at last are as fine as the hair of one's head. The lowest leaflet of each pinnæ has no stalk, but for the most part a narrow attachment, and is distinct from the rachis. All the other leaflets are decurrent. The leaflets are blunt, serrated at the summit, of an oblong form, toothed or serrated likewise in the sides. The pinnæ are very numerous and near one another, sharppointed, and forming a very acute triangle. The covers of fruit are lead-coloured, very enduring, kidney-formed, having their margins much bent downwards. The clusters 
are smaller than those of the regular form. The under surface of the frond is of a paler green colour. This deserves notice, as in the other forms there is no difference. Newman says, "The fronds are narrow-lanceolate." Moore says, "Broad-lanceolate." Our specimens are truly lanceshaped. In a fine group they are sometimes five feet high. The mid-rib of the pinnæ are more or less tinged with purple, and often there is a purple spot at their base. If this variety were placed in some of our wild neglected spots, especially if the ground be moist, and made an undergrowth to our wooded slopes, this golden coloured wilding would convert naked and unpicturesque hills into the most romantic and lovely scenery.

This form of the Male Fern is found in many of our wet woods; whosoever searches for it, should particularly look out for the golden coloured scales, which so abundantly cover the stalk and root-stock.

\section{Dark-SCALed Fers. Lastrea dilatata.}

See page 26.

Diminutive Dark-scaled Fern. Pumila. In describing the parts of a Fern, (page 6) the Dark-scaled Fern, Lastrea dilatata, was selected as presenting an illustration of a tripinnate frond. This variety differs from the ordinary form, inasmuch as it is only bipinnate, $i$. e. no leaflet of any pinna is distinctly branched. The scales are rery light, and only faintly darker in the centre. The frond itself has an almost triangular outline. The plant is scarcely a foot high. The leaflets are broad at their extremities and coarsely toothed. It is found in our shady woods and hedge-banks, in rather dry elevated situations, in a wood at Lambert's Castle in Hawkchurch parish, at Wiscombe Park in Soutbleigh, Forde Abbey, \&c.

Common Prickly Ferx. Polystichum aculeatum. See page 33.

Lobed Prickly Fern. Lobatum. In the Common Prickly Fern there are auricles (little ears) to many leaflets of a 
pinna, and these are placed on the side which is most distant from the mid-stem; in this they are only on the lowest leaflet, and there, too, not very visible. This is also a much smaller plant, about a foot high, and has a very narrow lance-shaped frond. It is stiff, leathery, chaffy, and of a yellowish green colour. The stalk is short. The leaflets, except the lowest on a pinna, are decurrent, and sometimes even that one is decurrent also. They are also convex, with their edges bending downwards, and their serratures ending in a prickle. Very few bristles are on the leaflets, sometimes only one on the summit. When a frond is kept in an herbarium of this variety, it is apt to fade and become a very pale green colour.

This is more frequently met with in our locality than the regular form. Most of the habitats assigned to the Prickly Fern, Polystichum aculeatum, apply to this variety. This has been found in the parishes of Axminster, Chard, Colyton, Hawkchurch, Stockland, and though not abundant, grows probably, more or less, throughout the district.

\section{Angular Prickly Fern. Polystichium angulare. \\ See page 35.}

1. Nearly tripinnate'Angular Prickly Fern. Sub-tripinnatum. This is one of the most handsome forms of the Angular Prickly Ferns. They are generally about a yard long. The leaflets are deeply cut at their edges. Those at the base of the pinnæ have frequently two auricles, not only an outer, but an inner one. The inner one is much the smallest, and that only attached to the lowermost leaflets of a pinna. These auricles are nearly, if not quite, distinct leaves. This is a plant of luxuriant growth, and has its pinnules pinnatifid or pinnate, which does not generally happen in this species. The frond itself is broader and stronger, though the foliage is not stiff or leathery. It seems questionable whether the plant would retain the same form if it were placed in a less favourable position for developing itself, and whether it would not degenerate into the ordinary appearance. If the little leaves of the leaflets 
were serrated and more decidedly formed, then this would be the variety decompositum of Moore. If the lowest upper leaflet of a pinna be much larger and longer than the rest, and be subdivided into several little leaves, then it is his tripinnate Angular Fern. The sub-tripinnate variety is very common in the neighbourhood, and the decomposite form is also frequently met with. If we see in our hedgebanks a group of large, fine, handsome Angular Ferns lying together in a dense mass, they are likely to belong to one of these forms.

2. Doubly-serrated Angular Prickly Fern. Biserratum. The leaflets are large, broad, and doubly serrated, distinctly stalked, and have bristles very conspicuous to the sight. The auricle is more deeply separated than the other lobes. The frond itself is rather broader than the generality of the Prickly Ferns. The stalk is long, and the clusters on the back of the frond not so crowded as in some other cases. This is a large, handsome Fern, and appears light and elegant, though the leaflets exceed the usual size of the species. This is not uncommon in most parts of the district.

3. Tiled or Imbricated Angular Prickly Fern. Imbricatum. The great characteristic of this variety is, that the leaflets are closely tiled and lap over one another. The fronds are narrow lance-shaped. The pinnæ are short and blunt. The leaflets have nearly four equal sides, with an auricle sticking out on the side opposite the rachis, and have a short bristle at the summit, and the tip of the auricle. Only the lowest leaflet of a pinna is stalked, the others are decurrent. It is said that this variety has bulbs on the stalks, by which new plants may be reared. If we mistake not, this grows between Hawkchurch and New Park in the parish of Axminster.

4. Proliferous Angular Prickly Fern. Proliferum. The old name given to this by Moore was angustatum, (narrowed) because its leaflets are narrow and acute. A very beautiful specimen of this has been taken from a lane near Greenway head, Uplyme. The auricle and the stalks are very conspicuous. The pinnæ are short and distant from one another. The whole frond presents a very light appearance. The leaflets are bright green and shining, and their narrow lance-shaped form, with the little projection at 
the base, gives it a peculiarly elegant aspect. The mid-stem or rachis in many cases most neatly undulates. Bulbs are produced at the points where the pinnæ meet the mid-stem. By these bulbs young plants are more easily produced than by sowing the spores. Not all the plants have these little bulbs. If this Fern be placed in a small flower-pot so that the roots have not fair play, then nature will have its perfect work, and the roots will arise above the surface of the ground in the form of bulbs. Thus we find the poet's assertion verified,

"Naturam expellas furcâ, tamen usque recurret."-Horace.

You may drive away nature with a pitch-fork, yet will she continually return.

5. Variable Angular Prickly Fern. Variabile. In all the other forms that have been described of this species, the branched leaflets or pinnules are little more than a fourth the length of the pinna, and appear only as leaves. In this, the rachis of the pinnæ often divides, sometimes almost close to the mid-stem, and at other times higher up, into two or three branches of nearly equal length. We may therefore say that such pinnæ are truly branched. Not all the pinnæ on the frond are thus divided. The unbranched ones are much the longest. This produces great irregularity in the outline of the frond. Thus, in our specimen, the plant tapers at the extremity for three and a half inches, where only a few of the pinnæ are branched. About two and a half inches beneath, the frond is three and a half inches wide, and the pinnæ are altogether unbranched. Between this point and the base, measuring seven inches, the pinnæ are shorter and separated into distinct branches, and the frond is only two inches wide. In some cases the frond is again wider near the base, and the branching ceases. Most of the leaflets are of the ordinary appearance, and doubly serrated. They have also rather long bristles. We have been thus minute in our description, to show how variable this form is. Others may be met with in the district larger or smaller, having their undivided and divided pinnæ in a different position. The distinct branching is the essential and leading characteristic. One plant has been found in the hedge-bank of a field near Axminster, close to the Lyme road. 
6. Variegated Angular Prickly Fern. Variegatum. A plant has been found in the neighbourhood of Hawkchurch, which is decidedly variegated with yellowish white. This has been tested for three years. As the black stemmed Spleenwort has been discovered, and foreign Ferns likewise, dappled with green and white, it is not surprising that this locality should have a Prickly Fern of this character likewise. Mr. Moly, of Hawkchurch, the discoverer of the plant, has transplanted it into his garden.

\section{Lady Fern. Athyrium filix femina.}

See page 38.

1. Deep-cut or incised Lady Fern. Incisum. This is a very fine and luxuriant form of the Lady Ferns, attaining the height of three or four feet. The root-stock is stout and firmly rooted. The fronds are large, broadly lanceshaped, and though not quite erect, may be described as slanting or gracefully drooping. The foliage is soft, the stalk and rachis are quite stiff and rigid. The stalk is about a fourth the length of the frond, black, and thickened at the lowest part. The mid-stem is by no means transparent. The pinnæ have distinct leaves, and would be linear if they did not taper towards the summit. The leaflets are large, long, gradually tapering, and deeply divided. Where they divide, the slit reaches almost to the mid-rib. These are also flat and have at the ends of their lobes two or three teeth. These lobes or segments are oblong, and have sometimes also at the sides a few sharp teeth. The clusters of fruit are generally curved, and when the covers disappear, are often crescent-formed rather than circular. This variety is common, and grows abundantly under hedge-banks where there are little purling streams. Magnificent specimens of this variety grow on the hedge-bank of a lane between Broadwinsor and Stoke.

2. Erect Lady Fern. Convexum, Newman. Rhoeticum, Moore. This is more delicate and frail, of a pale green colour, and a softer texture. The root-stock is very stout, firmly fixed in the soil, and difficult to be eradicated. The 
stalk is short, thickened, and wide at the base, with dark tipped brown scales. The frond is bipinnate, and grows erect, one or two feet high, sometimes more. Its appearance, though graceful, is never so fine and luxuriant as that of the preceding species. The rachis and stalk is four-sided, somewhat transparent, and often tinged with a reddish colour. The lower pinnæ frequently bend downward, and the higher ones upward, with a slight tendency near the summit to turn back. The leaflets, owing to the edge curling back, appear quite linear, but if they were expanded, it would be found that they are wider at the base, where there is a jutting out of the side, and after that jutting out, that they then taper to the extremity, and are, in fact, triangular. They have no distinct stalk, but a broad attachment, and are distant from one another. When the covers of the fruit disappear, the clusters are almost round, and spread over nearly the whole of the under surface. This grows in more exposed situations, in our wet commons rather than our woods and sheltered hedge-banks.

3. Plumous Lady Fern. Plumosum. Elegant as the Lady Fern always is, this variety is still more elegant and graceful than the other Ferns of the species. Though the fronds are frequently very large, yet nature has so adjusted all its parts, so neatly divided every portion of the leaflets, given it such a soft green colour, and so raised it in an erect position without being stiff and awkward, that we may pronounce it the fairest of the fair. If it could be imagined that the King Fern, the Royal Flowering Fern, Osmunda Regalis, should select any other as the object of his choice, and make her his bride, this surely he would fix upon and in this be would delight. The root-stock is very large. The stalk or leafless part is a fourth the length of the frond. The rachis or mid-stem is woody. The frond is egg-shaped or broadly lance-shaped and tripinnate, as the lowest pinnules or leaflets of some of the lower pinnæ are subdivided into little leaves. The rachis of a pinna is sometimes waved and often of a purple colour. Some pinnæ are nearly a foot long. The leaflets are much more deeply toothed than in the variety incisum. Several of the finer ones are two inches long. The covers run nearly in a straight line. The clusters of fruit are in the slit, and their position is by no 
means symmetrical. When the pinnules have no stalk, they have a rather broad attachment. The preceding varieties have each pinna distant from the next, and in dried specimens appear quite distinct. In this variety, the vegetation is so luxuriant that one crowds upon and laps over its neighbour, so that it cannot by any contrivance be separated. In the variety (No. 1.) the lobes of the leaflets are toothed at their edges, but the teeth are not very long or very conspicuous. In this, the much longer teeth and jagged edges of the lobes have a most pleasing and delightful effect on the eye. The leaves are flat, not bent down as they are in the convex or erect Lady Fern. No bristle points are visible as in the Prickly Fern. This beautiful, charming, and lovely variety is another of those interesting plants with which our neighbourhood is so richly supplied, and it seems that a journey must be taken to Yorkshire ere we can find it growing in its natural haunt again. It grows in a meadow in the southern division of Stockland parish.

In this instance we see a striking difference between a species and a variety. To an ordinary eye, or to a young botanist, it would appear that the Plumous Lady Fern was most certainly a distinct species. The plant appears so much superior, the vegetation so remarkably more luxuriant, the various lobes and leaflets so deeply and elegantly cut, that it could never be imagined to be identical with the usual form of this Fern. When, however, any one sits down and attempts to point out any unvarying distinction, be perceives that the difference only consists in the fuller development of the plant and the magnified representation of every feature.

\section{Maidenhatr Spleenwort. Asplenium trichomanes.} S'ee page 41.

Forked Maidenhair Spleenwort. Furcatum. This differs from the usual character of the Maidenhair Spleenwort in having its head divided into two or three branches. Plants have been found in the hedge-bank of a lane between Alston and Churchill, in the Parish of Chardstock. Many fronds, but not all on the same root-stock are forked. 
Buack-stalked Spleenwort. Asplenium adiantum nigrum See page 42.

1. Forked Black-stalked Spleenwort. Furcatum. A plant has been discovered growing on a hedge-bank of the turnpike road on the Axminster side of Musbury, with all its fronds forked at the summit. The divisions were blunter at their ends, and the clusters of seed nearer the margin of their leaflets, and in a shorter line than in the ordinary form.

2. Variegated Black-stalked Spleenwort. Variegatum. Several plants of this variety grow in the hedge-bank of a lane between Kilmington village and Shute Lodge. Its only difference is, that it has its leaves variegated with very pale yellow. The pale colour is principally found on the edge, and a few light spots also appear in the central parts of the leaflets. Even in the dead fronds the variegation is visible. It is probable that in many other parts of the district this variety will be discovered.

\section{HART'S-TONGUE. Scolopendrium vulgare.}

See page 52.

1. Curled Hart's-tongue. Crispum. If we look carefully over the hedge-banks, especially near Hawkchurch, we shall sometimes see the margin of this Fern very much waved and plaited, or curled like the old fashioned frill of a shirt. This is crispum. Moore says that "it is usually barren, but sometimes fertile." Elegant as this variety is, dried specimens do not appear to advantage, as the necessary pressure destroys all its beautiful curls.

2. Much-cleft Hart's-tongue. Polyschides. Let us make another careful survey and look with an eagle eye into every crank or corner of our hedges and ditches, or shady walls and wells, and we may chance to light on the Much-cleft Hart's-tongue. The edges are a little crimped, but the great peculiarity here is, that the fronds are gashed and torn on each side, and jagged and notched on their edges. In various parts a piece or lobe bulges out on the margin, and no regularity or symmetry is preserved. The frond is of a moderate size, about a foot long. This Fern did not 
escape the notice of Ray, the great father of English botany, who designated it "Bobart's much-cleft Phyllitis tortured by every lobe being jagged."* This variety is by no means uncommon.

3. Lobed Common Hart's-tongue. Lobatum.

Improbus."-Virg.

"Labor omnia vincit

Earnest industry overcomes all difficulties.

If we would thoroughly investigate nature's productions, we must take some pains. Another search must now be made, and a little more trouble taken, and we shall meet with a Hart's-tongue forking either at the head or lower down, sometimes even below the middle, into different lobes, which are again subdivided, and sometimes even for a third time, and then taper into a sharp point. A little before the frond branches, it widens itself, and previous to its thus widening, it has a linear form and a heart-shaped base, as is the general character of the species. The mid-rib also divides with each division and subdivision, and the fructification lies on each side of the mid-rib wherever the mid-rib be. These monstrosities are not uncommon, and have been found at Musbury, Weycroft, and Secktor, in the parish of Axminster, and near the villages of Hawkchurch and Chardstock.

4. Finger Hart's-tongue. Multifidum. Here is another variety differing from the last, though very much allied to it. This frond separates into two or three parts, in some cases near the head, in others not far from the stalk or lowest part. About an inch or more from its topmost part it begins to expand and becomes decidedly fan-shaped. This variety does occasionally, in small specimens, appear to be triangular. The summit is much subdivided and curls itself together, as in the leaves of endive. The mid-rib of this, too, runs into each lobe, and rather short clusters of spores accompany them. When we have a stunted plant, the whole frond looks like a fan suited for the pigmy race to cool themselves with on a hot summer day. Old Gerarde calls this "the Finger Hart's-tongue, Phyllitis multifida." In his description he states, "that the leaves thereof are cut or jagged like a

* Phyllitis polyschides laciniis singulis oruciatum decussatis Bobartii. 
man's hand, or the palm of a brow antler of a deare,* bearing neither stalke, floure, $\dagger$ nor seed." $\mathrm{He}$ is incorrect in stating that there is no fructification, as our plants are fruitbearing, but the clusters are not so large as in the ordinary form. This is an elegant variety, and in a damp, shady situation thrives, and is improved by cultivation. It is found growing in Hawkchurch parish rery luxuriantly.

5. Branched Hart's-tongue. Ramosum. Here the Hart'stongue assumes another form, and the stalk itself is branched. Each branch is strap-shaped until it approaches its summit, then it expands and resembles a little fan dividing itself into two or three parts, which separate again near the apex into sundry little segments that have a crisped and curled appearance. As in the others, so here, the mid-rib divides and runs into the respective lobes, and the clusters of spores are on both sides of these ribs. The stalk is of a dark purple colour, and the scales much the same as with the typical plant. This, too, is a handsome plant, and in a damp, shady border, where no flower would grow, would be no despicable ornament to a garden or shrubbery. It has been found in Hawkchurch parish.

6. Simply Branched Hart's-tongue. Simpliciter ramosum. This also has its stalk branched. As it is very different from the last, it seems best to assign it a distinct name. The segments at the topmost part of the preceding, have a curled appearance. Here there are no segments whatever in that part of the frond, neither are they curled. The forms of the leaves are most grotesque. Sometimes each leaf is kidney-shaped, sometimes as round as a penny, with a gash in the middle, sometimes a mis-shapen triangle. Some plants have their leaves so formed that at first they rise up as it were in a straight column, and then bend their arms right and left, tapering to a point. It would be endless to describe all the changes and frolics of nature in this plant. Even the old Herbalists had their Finger Hart'stongue, and their Mule's Fern, and the Small Moon Fern, and the Handed Moon Fern, and most of these represented as growing in England. Are we then to wonder if we have some of these curious productions? These strange looking malformations have been sent, as gathered in a lane near the

$$
\text { - Deer. + Flower. }
$$


village of Hawkchurch, also at Berry lane in the same parish, and near Monkton Wylde, on the western side, a pleasant walk for Charmouth visitors. Another authority states, that they are to be found near the village of Chardstock.

\section{Northern Hard Fern. Blechnum Boreale.}

\section{See page 55.}

Forked Hard Fern. Furcatum. Here we have a fourth species which has a variety that forks the fronds. In this plant sometimes the stalk, and sometimes either the barren or the fertile fronds, or both, separate into two parts. Both at Bulmore farm in the parish of Axmouth, and at a boggy spot in Hawkchurch, plants have been found in which many fronds were thus divided. It is most probable that some of our Northern Hard Ferns will be discovered in which all the fronds assume this form. In Chobham, Surrey, fifty such plants are to be found growing wild on an uncultivated common. Undoubtedly then, there is a variety of Forked Hard Ferns. Certain plants, especially among the sea weeds (Algæ,) have a tendency to be what is technically denominated dichotomous or forked at their ends. Any one who studies those beautiful natural productions, cannot fail to notice this peculiarity.

An account has now been given of twenty-seven varieties or abnormal forms of various species of our Ferns. In some of these the difference is very slight; in others so great that a person uninformed would think it impossible that they constitute the same species. Four have been mentioned as chiefly differing in having their fronds forked either at their apex or their stalk. This is no great distinction, but sufficient to constitute a variety if it constantly happened on the same plant. In two that have been described, only a portion of the fronds are thus dichotomous, and therefore these are not strictly varieties. As, however, in other places it has been certified that this constantly happens in these two particular Ferns, we have inserted them in our list, in 
the hope that other more satisfactory specimens may be found in the district of the Axe. As to the Polypodies and Hart's-tongues, some may also object to their being considered varieties, inasmuch as only a single plant here and there can be found out of a vast number which departs from the regular form. It may be very properly asserted, that these are monstrosities, not varieties. If, however, we cast away all monstrosities and deem them not worthy our consideration, our gardens and our shrubberies would lose much of their beauty and elegance. What is it that makes the borders and parterres of our nobility and gentry appear so lovely? For what are handsome prizes offered at our Floricultural and Horticultural Meetings? What is it that the nurseryman and gardener strive to produce by dint of the most skilful cultivation? Monstrosities. The single rose and stock is nature's production; the double rose and double stock are monstrosities, deviations from nature's ordinary course. If the matter be considered in a scientific point of view, very few that have been mentioned are vari. eties. Not one of the forms of the Hart's-tongue deserves the name, much less are they species, as the nursery gardeners call them. They are rather monstrous and unnatural appearances. We do not find a large group assimilating to the typical form, as in the varieties of the Male Fern, Lady Fern, \&c., but sometimes we shall find one plant here and there surrounded by Hart's-tongues of the ordinary character, with one frond or all its fronds assuming a grotesque appearance. If we meet with one man in England, and another in India, seven feet and a half high, and with a dwarf in like manner as short as Tom Thumb, we would not consider them a variety of the species man, but as an extraordinary appearance, some lusus naturce, some deviation from the usual course of things. Moore says, "That most of these monstrosities are produced from spores (seeds)." We know that in the productions of nature there is always a tendency for the offspring to represent its sire. A tall father has frequently a tall son. The Insurance companies are generally averse to insure a person's life when the father or mother has died of consumption. Why is this? Because they consider that the child's constitution will resemble that of the parent. In like manner, it is not surprising if a plant 
which has a curious appearance, should sometimes beget a progeny like itself. As, however, the primitive form is often produced from the spores, we can hardly consider them a variety, much less a distinct species.

Varieties are defined to be a large group of a species differing from the regular appearance of that species, but approaching to it by intermediate plants. These varieties, as long as they live, always maintain the same form, and the spores, if, sown in the same situation and under the same circumstances, would generally produce the same form of plant. If they are transplanted they would not alter, but still maintain the same character, though if the soil and situation be favourable to the growth of another variety, most probably the spores would bring forth that other kind. Wherever, therefore, we meet with a variety, we shall rarely light upon only a single plant in that neighbourhood, and certainly in some other district a group will appear.

A monstrosity is reputed to be a single plant, or a very few out of a large number, which are changed or transformed in some extraordinary manner. The alteration brought about by insects or blight is not to be taken into the account, for when that action ceases, the transformation ceases also. Sometimes a single frond only deviates from its usual aspect. This is not worth consideration. It is the change of the whole plant that ought to be thought of importance. In some cases a partial malformation has been noticed. This has been done, because it is an indication of a monstrosity or a variety that exists in other parts of the kingdom, and may be a clue to the discovery of the same in this. The partial malformation is the connecting link between the variety or monstrosity, and the regular form. Thus a herb or shrub, that bears on the same stock both double and single flowers, is an intermediate form, that shows, however much the double and single flower plants seem to vary, they are identically one species. As generally only a single individual monstrosity appears in a place, the habitat of that one is of no use to the fern collector, as there is no certainty of others being found in the same spot. Of course, as in varieties, so in these abnormal appearances, climate, soil, and situation have a most powerful effect in bringing about these transformations, and there 
is, undoubtedly, a greater likelihood of meeting with aberrations from nature's usual routine in some places than in others.

One further remark must be made. Let not the student of nature's works be perplexed, because he finds it more difficult to discover these deviations from the ordinary form than to ascertain the species. It is the very essence and character of such, that there should be a gradual approximation to the original standard. The matter in fact is like the shifting sand of the ocean. Some Ferns will appear to come nearer to the typical plant, and others to the variety. There are intermediate steps to prove the beautiful gradation in God's works. 'There may be a great difficulty in coming to a decision, and, after all, we must be satisfied, whether we study the animal or vegetable tribes, if we have something like the features and outlines furnished by the most approved authors, and in accordance with common sense.

In bringing to a close our remarks on the Ferns and their varieties found in the parishes through which the Axe and its tributaries flow, and also in the parishes of Charmoutb, Lyme, Uplyme, and Monkton Wylde, we crave the indulgence of our readers, while we make another attempt to facilitate the discovery of the different plants. Let it again be observed, that all our Ferns except the Adder's-tongue and Moonwort are circinate in their vegetation, i.e. before the fronds are expanded, the buds are coiled together in a circular manner. Any one who casts his eyes on our various hedgebanks in the spring, cannot fail to notice how differently the Ferns seem to come into leaf from any other plant. The Ferns have the seed vessels on the back of the frond, except the Flowering Ferns, which are the Adder'stongue, the Moonwort, and the Royal Fern, Osmunda Regalis, and all except these have, as is seen under a microscope, their bags of spores or seed surrounded by an elastic ring. If, therefore, the Fern is not circinate in its vegetation, nor has the fruit on the back of the frond, nor its bags of spores surrounded by an elastic ring, we may rest assured that it is the Adder's tongue or Moonwort. 
If it is circinate, but has its fructification on the ends of the fronds or their branches, and still no elastic ring, then we may be satisfied that it is the Royal Flowering Fern. These have no covers to their fructification. We have one more species that has no cover. Now, if we see a Fern that has its masses of spores on the back of the leaves without a cover, we may be confident that it is the Common Polypody, unless any of our friends should chance to light on the Lime-stone Polypody, (Polypodium Calcareum) which has not been described in this book, and which would be a treasure indeed. If it has a round cover with a slit in it, and attached at the inmost point of that slit, then it is a Shield Fern, Lastrea: if it has a round cover without a slit and attached at the centre, then it is a Prickly Fern, Polystichum. If it be a linear cover, and that a curved line, and attached the whole length, then it is that genus of the Spleenworts which is called Lady Fern, Athyrium. If the cover be a straight line and attached along the sides of the veins of the leaflet, then we have all the other Spleenworts, Asplenia. If the straight cover be in pairs, then it is a Hart's-tongue, Scolopendrum : if it is obscure, and the masses of fruit are hid by scales, then it is the Scaly Spleenwort, Ceterach. When the straight linear cover is parallel with the mid-rib, it is a Northern Hard Fern, Blechnum, and when it is on the margin and originates from the bent-in edge of the frond, it is Brake, Pteris.

It is hoped that these hints, as well as those given in the commencement of the volume, will serve to remove any difficulty that may arise in attempting to discover the various Ferns of the neighbourhood. Several have been drawn already to amuse themselves with this simple study as a recreation, in consequence of our observations previously thrown out in a local newspaper. The endeavour has been made to make the subject understood by every class, and it is the source of no little pleasure to find, that not only the gentry, but the humble classes and mechanics have felt interested in the wild productions of their own locality. 


\section{A P PENDIX.*}

\section{Angular Prickly Fern. Polystichum Angulare. Page 69.}

1. Dense Angular Prickly Fern. Densum. Mr. Moore seems to have given the distinguishing name to this variety, because the leaflets are crowded together, and the rachis of the frond and of each pinna is densely covered with hairy scales. It may be observed that the leaflets are rounded at the summit, with its ear or auricle distinctly sticking out at the base. If the auricle were cut off, they would then be egg-shaped or oblong. The leaflets are also small, stalked, and serrated; the lowermost on the upper side of each pinna is longer than the rest, and divided at the edge into very small but distinct lobes. At the extremity of each serrature there is a short bristle, and these bristles are very conspicuous. The scales of the stalk are not hairy, as those of the rachis, but broadly lance-shaped, shining, light brown, and transparent. The frond is not so remarkably drooping as most of the Angular Ferns, and is rather erect than horizontal. Its form is lance-shaped, and rather tapering toward the apex. Occasionally there is a little irregularity in the length of the pinna, but this is not sufficient to disfigure the plant, which, with its congeners, has a fair and goodly appearance, and though not so luxuriant as other varieties, is neat, light, and graceful. Our fronds are about nine inches long. It bas been found at Dalwood and Kilmington.

\section{Dark Scaled Fern. Lastrea Dilatata. \\ Pages 26 and 68.}

2. Dark Scaled Fern of the Hill. Collina. This is a very beautiful variety, having a dark green frond, sometimes

* The three varieties inserted in the Appendix, were discovered after the pre. ceding sheet had passed through the press, 
triangular, and sometimes lance-shaped, with a much shorter stalk, scarcely half its length, and thickly covered at its base with dark scales, which have a transparent margin and their very tips almost black. The two pairs of the two lowest pinnæ are triangular: the others linear. The first upper pinnule of the lowest pinnæ is much shorter than the first under one. In every other pinna there is very little difference between the pinnules that are above and below their respective rachis. The lowermost pinnules of the lowest pinnæ are nearly, if not quite, divided into distinct little leaves, and hence the plant is almost, if not altogether tripinnate. Many of the pinnules, too, nearest the rachis of the frond, are either stalked or have a broad stalk-like attachment: the others are decurrent and run more or less into one another. The leaflets have linear segments ending in remarkably coarse blunt teeth, a striking mark of distinction from the ordinary form. If we closely examine the under parts of the leaves, we shall observe that they are thickly covered with minute stalked glands. The covers of the fruit, when seen under the microscope, appear to be jagged, and also fringed more or less with stalked glands. The clusters or sori are generally in two rows on each side of the mid-vein of the leaflets. If the pinnules are almost or altogether divided into distinct leaflets, the divided parts have two rows likewise. The fructification, though small, is abundant over the whole frond. There is another peculiarity, that the stalk is for the most part green, and only purple close to the base. Most of the pinnæ are nearly at right angles to the mid-stem, and distant from each other. The lobes of the leaflets are blunt at their extremities, where there are two or three coarse teeth. Whether it be owing to the pure air of the hills, or to the inherent character of this variety, it has a more elegant form than any of the other Dark Scaled Ferns. It does not attain so great a height, neither does it stretch out its arms so widely, still it is prettier in its mode of growth, and much more erect with spreading or bending branches. The very coarseness of the teeth, the dark green colour, and the distance of the pinnæ from each other, give it such peculiar grace and symmetry, that the lover of nature should not hesitate to take a long walk to secure to himself a good specimen of the Fern of the Hill. 
Newman states, that though he feels a difficulty in giving anything approaching to a satisfactory specific description, still, influenced by a peculiarity which arrests the eye, he is inclined to consider it a distinct species. This variety has been found growing in Shute parish.

3. Narrow-leaved Dark Scaled Fern. Angusti-pinnula. Moore. This chiefly differs from the preceding in having narrower leaflets or pinnules. The pinnules, too, vary in length. A shorter, or stunted, or imperfect leaflet here or there appears on a pinna. In most cases the fronds of this character were intermixed on the same plant with those of the preceding variety. It seems, therefore, that ours is only an approach to what Moore calls Angusti-pinnula. This also grows in Shute parish. 


\section{THE CULTIVATION OF FERNS.}

Thene are five methods whereby various Ferns may be obtained. 1. Sowing the spores. 2. Dividing the plants. 3. Taking off bulbs and putting them in the ground. 4. Laying the tips of the fronds. 5. Transplanting. With respect to transplanting, many observations have been already made. To the other methods the attention of our readers shall be more especially directed.

1. Sowing. In order that the care requisite in sowing may be better understood, the way in which germination takes place needs to be explained. A Fern is said to be a not-flowering plant, a plant in which the seed is not produced by impregnation. Every flower-bearing herb, shrub, or tree, has in its flowers a stamen and a pistil. On the highest part of the stamen is the anther, which contains a powder or dust, called by Botanists, pollen. In like manner on the top of the pistil is the stigma, on which lies a glutinous substance. A perfect seed is produced by the dust of the anther falling on the gummy substance of the stigma. This is called impregnation. In some plants one flower has the stamen, and another the pistil. In this case the dust from the anther of the stamen must be brought some little distance to the stigma of the pistil or no fruit will be produced. This is done by the operation of the air, or through insects. In most of the sedges the stamen flowers are seated above the pistil flowers, so that the powder naturally falls down on the stigma, which is ready to receive it. In the cucumber, the wind helps nature, and carries what is necessary to its destination. When the plant is under a frame, the skilful gardener remedies the defect arising from the wind being excluded, by taking the stamen and placing the dust on the stigma, and thus a cucumber is produced. As a still further illustration, the date has not only distinct flowers, some of which bear only stamens, and others only 
pistils, but has this further peculiarity, that no one of these trees bears both kinds of flowers. The Egyptians only cultivate the trees that have fruit-bearing flowers. Every year they send to Abyssinia, at the proper season, for branches covered with the other flowers, and hang them up on their own date trees, and thus impregnation takes place. When the great Napoleon made his celebrated invasion, that people were so much engaged in defending themselves, that they neglected to fetch these branches of flowers as they had hitherto done. What was the consequence? During that year there was not a single date in Egypt. Now Ferns are considered not-flowering plants, and therefore nothing like impregnation is supposed to happen to them. This seems strange, as some of them are very large, even magnificent forest trees. They also differ from most others belonging to this portion of the vegetable world in not having a cellular, but vascular tissue, and in possessing woody fibre. Hybrids, also, are occasionally produced. In flowering plants a hybrid is said to be formed by the pollen of one species falling on the stigma of another. Thus if a nurseryman has a choice turnip,* and wishes to save the seed of it, he is very careful that no other species of the genus should blossom near it, lest, as the common saying is, the bees should inoculate it, i.e. carry the powder or pollen of the one to the stigma of the other, and the seed would consequently produce a hybrid or inferior plant. If there are then hybrids in Ferns, and experienced gardeners maintain that there are, it is probable that something similar occurs to what happens in flowering plants. What seemed so likely, has been ascertained to be true by interesting experiments. There is, however, this difference, that in ordinary cases impregnation takes place before the fruit is formed, while in Ferns it is after the production of the spores. It appears that when the spores germinate, a thallus or leaf-like scale arises. On this scale appear what corresponds both to the anthers and stigmas in flowers. The first are called antheridia, and the second ovules. The dust or pollen of the one duly affects the other. If, therefore, we suppose that the spores of the different species are near one * This is mentioned because there are so many allied species, cabbages, charlock,
\&c., through which hybrids may be formed. 
another, and afterwards these organs of reproduction arise, it can easily be conceived how the pollen of one species may fall on the ovule of another, and thus a hybrid Fern be formed.

It is now evident, that, whoever wishes to have a particular Fern, must be very careful not to sow the spores of any other in the same place. The agriculturist knows how he damages a crop of corn by selecting bad seed. The gardener, too, will have a sorry exhibition, if he thoughtlessly intermixes his spores. These rules apply to the foreign as well as the beautiful productions of our own neighbourhood. The spring is the best period of the year for sowing. Small pots should be selected. Half the pot should be filled with earthenware broken very fine. This will prevent the water stagnating. A thin layer of bog moss (sphagnum) should be spread over these sherds. A compost should then be made of loose bog earth and white sand. The bog earth must first be crumbled and placed in a hot oven, that any lurking organic matter or worms may be destroyed. When this compost is duly prepared and thrown on the bog moss to less than an inch from the highest part, it should be watered. The spores should then be sown, but care must be taken that they be not too thickly strewn or too much watered, as they are apt to crowd and kill one another. After the first time the water should never be placed on the earth, but in a saucer underneath. A plain flat piece. of glass, or a bell-glass should be put on the pot, which should be placed in a light but shady place. When the young plants appear, and they appear in green scales almost transparent, a little air may be at first admitted, and that increased by degrees. If they are too thick, they must be thinned by taking off patches here and there, and planting them in similar pots. As this is apt to disturb them, it is much better not to sow them too thick at first. Some sow them on little pieces of sandstone or broken brick, but in such cases there is great difficulty in transplanting. As the plants grow, they must be adapted to their natural climate, to the greenhouse, stove, or open air, but in all cases moisture and shade is desirable. Stagnant water must be avoided.

2. Ferns may also be propagated by dividing the rootstock. If it be a creeping root-stock, it should be so divided 
that each portion has a frond or two on it, and some fibrous roots. They should be set in loose soil made of sand, bog earth, and leaf mould. No great depth of this earth is required, neither much watering, as these are air plants, chiefly deriving nutriment from the air. Such also grow well if suspended on blocks of wood, covered with damp moss, in a warm atmosphere, or if placed in little chip mossy baskets full of chinks, they force their way through in an elegant and graceful manner. In the winter they should have still less water than in the summer. The Polypody is almost the only Fern of the Axe having a creeping root-stock, which is suitable for such a mode of growth. If a similar attempt be made with the Brake, a young plant must be selected, and the root-stock must be cut short every autumn. The Spinous Fern will not thrive under such management, as it bears a great resemblance in character to the other Shield Ferns. If the root-stock have a crown,* it should be narrowly examined whether there is more than one tuft or crown. If there are, then the knife must be applied, and the plant so separated that each separate part should retain a portion of the roots. Care must be taken not to cover the crowns, which is certain death to the plant. This requires a deeper soil, and more frequent watering. The spring season, just before its vital properties are resumed, is best adapted for such operations.

3. It has been noticed, pages 70 and 71 , that some indigenous Ferns produce bulbs. This happens more frequently in Exotics. These may be taken off and placed in pots with the other requisites, and earth prepared similarly to what was required for sowing. Little plants soon rise resembling the parents from which they are taken. As it is a great-rarity to meet with a bulb-bearing wildling, any further observation on this mode of culture is unnecessary.

4. Others root from the tip of their fronds. As the old laurel is made to produce a young one by having its shoots pinned down and a layer formed, so some of the Spleenworts and other Ferns will grow if the tip of the fronds are fixed near the soil. The division of these must be done most carefully. Very seldom are fine specimens obtained by such

* Root-stocks are said to have a crown when the Ferns grow in tufts or shuttlecock fashion. 
means. It is probable that the new plant partakes of the age of that from which it is severed, and never enjoys the freshness of youth. For a similar reason many have considered, with regard to grafting fruit trees, that the grafted shoot participates in the age of the tree from whence it is taken, and hence account for the good old fashioned fruit of our forefathers becoming extinct. The only way of having what is young, strong, and healthy, is by sowing occasionally.

5. Finally, as to transplanting, so much has been said in the course of the work that little more need be added. It must never be forgotten that the roots should not be broken. The natural situation, position, and soil, should be imitated. A lady wished to have some Maidenhair Spleenworts interspersed with her other Ferns. She placed earth in a saucer and planted them in it. They languished and died. She set the saucer in an erect position after inserting new ones; they now were in their natural place, and began to thrive, and exhibit their pretty round leaflets with black shining stalks. The vertical position may also have served to drain off the stagnant water, and for this reason have caused the experiment to be so successful. Most Ferns love damp situations and watering, but there should be a free circulation and no stagnation. They also delight in shade. Even those which grow in the sun, are finer and more luxuriant in a less exposed situation and in a northern aspect. Smaller species prefer a shallow soil, and few are fond of rich, highly conditioned, valuable ground. It is not on the banks of the Axe, or in our well-farmed, well-watered meadows, that our finest plants luxuriate, but in the poor, hungry, loose soil close to the streamlets, which feed and supply our river as it wends its course onward, until it is lost among the waves of the English Channel. It may be further observed, that if the rich ground of the lowland country be altogether neglected and saturated with wet, it yields abundant crops of reed and sedge in dense, unapproachable masses. No Flowering Ferns or Shield Ferns there. The old writers used to say, that reed and fern have a deadly enmity one to the other. On the other hand, if there be woods in more elevated positions with loose soil, and in a damp situation with the water dripping down some gully, or dashing and foaming over some crag or rock so hastily and so grandly; 
nay, if there be only some huge hedge bank in a narrow lane, with overhanging majestic oak trees, or, if there be on some great eminence an old ruin, which was once our forefathers' boast and defence, but is rapidly falling into decay, embosomed in thickets and forests, in such places as these may we expect to behold the Ferns in all their loveliness and grandeur. 


\section{LOCALITIES OF THE RARER FERNS.}

THE writer has not visited the places marked by an asterisk. In most instances he has seen specimens of the Ferns, and all the habitats are stated on reliable information.

Chaffcombe ought to have been inserted in page 3 as one of the parishes, since a portion of its waters is tributary to the Axe.

\section{Adder's Tongde. Ophioglossum Vulgatum. Page 11.}

The habitats of this not uncommon Fern are mentioned, as on account of its diminutive size, and its growing in pasture fields, it is likely to escape observation.

Axminster; in fields near Eril Lane, Lodge Farm, Greatwood, and near Wyke.

* Axmouth ; in various pasture fields.

Chard ; in meadows between the Reservoir and the Crewkerne road.

* Chardstock ; fields near the base of Tytherleigh hill.

Charmouth ; fields near the pathway to Wootton.

* Churchstanton; Burnworthy.

* Cotleigh ; in various fields.

* Otterford ; fields above Whatley lime quarries.

* Southleigh; fields near Wiscombe Park.

Moowwort. Botrychium Lunatum. Page 12.

Axminster; New Park.

* Hawkchurch; south of Fishpond bottom near Lambert's Castle.

* Southleigh; Castle down near Wiscombe Park. 
Royal Flowering Fern. Osmunda Regalis.

Page 15.

Axminster ; Higher Beaver Batches, Furzeleigh, the Moor, and New Park.

* Beaminster; Meerhayes.

Buckland; in a ditch at the east end near Otterford.

* Chaffcombe ; in a boggy wood near Avishays.

* Churchstanton; on Blackdown hill one mile and a half south west of Holmen Clavel.

* Colyton; Borcombe, and in a bog near Hangman's Stone.

* Combe St. Nicholas; Copse in Combe Wood.

Hawkchurch; Cowse.

Monkton Wylde.

Northleigh ; between Road Pit and Ball's Cottage.

Offwell ; Colwell Moor, and Copse of Smallcombe.

Southleigh; Bullhall Copse in Wiscombe Park.

Stockland; Colmar Copse close to Ridge.

Uplyme; in dells near Woolly Head, and in *Hole Common.

* Yarcombe ; in a marsh.

Common Pourpodr. Polypodium Vulgare.

Forked Common Polypody. Pol. vulg. Bifidum.

Page 65.

Axminster; between Weycroft and Smallridge.

Chard; Chardstock road, and Tatworth.

Hawkchurch; between that place and Broom.

Musbury; at Hob-knap.

Auricled Common Polypody. Pol. vulg. Auritum.

Page 66.

* Combe St. Nicholas; near Wadeford.

Dalwood; near Sunnyland.

Hawkchurch, Cowse.

Musbury; in the hedge-bank of a wood near Bullmoor. 
Sharp Pointed Common Polypody. Pol. vulg. Acutum. Page 66.

Axminster; near Secktor.

Chard; Paradise lane.

Dalwood.

Kilmington ; between the village and Shute.

Many-formed Common Polypody. Pol. vulg. Multiforme. Page 66.

Northleigh; in a hedge-bank of a Common.

\section{Sweet Mountain Fern. Lastrea Montana.}

\section{Page 21.}

Although many localities are enumerated, this Fern is not generally common in the neighbourhood.

Axminster; New Park.

Broadwinsor; Loosdown.

Chaffcombe; in a field north of Avishays.

* Chard ; between the town and Avishays.

Chardstock; in a gully near Alston on Birch-hill Common, and * at the edge of a wood near Beacon-hill.

* Charmouth ; in Langmoor Copse.

Churchstanton ; in fields near the Rectory.

* Dalwood ; north of Danes-hill.

* Hawkchurch ; Stoodley's hill.

Kilmington ; in the old road to Honiton near the village.

Monkton Wylde; lane near Warren House.

Northleigh ; between Road pit and Balls Cottage.

Offwell ; bank of Smallcombe Copse.

Otterford ; very common.

Shute; near the eastern Lodge.

Southleigh; Wiscombe Wood.

Stockland; hedge-bank near Colmar Copse, Ham Lane, and * in the lane between Kilderhayes and Penny hill.

Uplyme; in a lane north of Woodhouse, and in a boggy Wood north-west of the village.

Wambrook; near Shagsplood. 
Wayford, near Crewkerne; Beerchapel.

Yarcombe; Woodend.

\section{Dark-scaled Fern. Lastrea Dilatata.}

Diminutive Dark-scaled Fren. Las. dil. Pumila.

Page 68.

* Dalwood ; Dane's hill.

Hawkchurch; Scatteridge, and in a Wood near the Inn at Lambert's Castle.

Southleigh; Wiscombe Wood.

* Thorncombe ; Forde Abbey.

Dari-soaled Fern of the Hill. Las. Dil. Collina. Page 83.

Shute; hedge-bank and ditch between the eastern Lodge of Shute House and the Honiton old road.

Narrow Pinndled Dark-scaled Fern. Las. dil. Angusti-pinnula. Page 85.

Shute; same as the preceding.

\section{HaY-scented Fern. Lastrea Fanisecii. Page 28.}

* Cotleigh ; in a hedge-bank on the road to Honiton.

* Monkton Wylde ; near Gamekeeper's Lodge. Southleigh; Wiscombe Wood.

Uplyme ; in a boggy wood on the north west-side, and at Greenway head.

* Winsham; Baymoor Copse.

Spinous FenN. Lastrea Spinulosa.

Page 30.

Chaffcombe; in a wet Wood between Avishays and the village. 
* Charmouth ; Langmoor Copse.

Stockland Hill; Mr. Jeremy's Plantation. village.

Uplyme; in a boggy wood on the north-west side of the

Common Prickly Fern. Polystichum Aculeatum. Page 33.

Axminster; between Millbrook and Weycroft Mill, and Wyke.

Chard; on the road to Axminster, and between Tatworth and Forton, also between Chard and Avishays.

Chardstock ; near Galloping Close.

Dalwood; between the village and Corry, and in Millwater lane.

Hawkchurch; between the village and Broom.

* Kilmington; between the village and Beckford Bridge.

Offwell ; lane skirting east and lower side of Colwell.

Stockland; Baker's meadow in Southmill farm.

Thorncombe;

Winsham; $\}$ not uncommon.

Lobed Common Prickiy Frre. Polyst. Acul. Lobatum.

$$
\text { Page-60, }
$$

Axminster; between Chard turnpike road and Smallridge. Chard; lane to Chardstock, and near Forton.

Colyton; near Tritchayne farm.

Hawkchurch; between the village and Broom.

Monkton Wylde ; in a lane adjacent.

Offwell ; lane skirting east and lower side of Colwell.

Shute; west of Luxhayne mill.

Thorncombe; between the village and Forde Abbey.

* Winsham ; Coleman lane.

Angular Phickly Fern. Polyst. Angulare.

Tripinnate angular Prichiy Fern. Polyst. Ang. Tripinnatum. See Subtripinnate, page 69.

Cheddington; Crook hill lane. 
Tiled or Imbricated Axgular Prichly Fern. Polyst. Ang. Imbricalum. Page 70.

Axminster; between Hawkchurch and New Park.

Proliferous Angular Prickly Frrn. Polyst. Ang. Proliferum. Page 70.

Uplyme; lane near Greenway head.

Variable Angular Prickly Fern. Polyst. Ang. Variabile. Page 71.

Axminster; in the hedge-bank of a field near the Lyme road.

Dense Angular Prickly Fern. Pulyst. Ang. Densum. Page 85.

Dalwood; Kilmington.

Lady FerN. Athyrium Filix Femina.

The habitats of the two following varieties are mentioned, not because the plants of this kind are rare, but because fine specimens are found in these places where Ferns are comparatively scarce.

Incised Lady Fern. Athyr. Fil. Fem. Incisum.

Page 72.

Broadwinsor; in a lane between the village and Stoke.

Cheddington; Crook-hill lane.

North Perrott; in a wood.

Erect Lady Ferr. Athyr. Fil. Fem. Convexum. Page 72.

Cheddington; Crook-hill lane. North Perrott; in a wood. 
Plurous Lady Fern. Athyr. Fil. Fem. Plumosum. Page 73.

Stockland; in a meadow of Southmill farm.

Matdenhair Spleenwort. Asplenium Trichomanes.

Forked Matdenhair Spleenwort. Aspl. Trich. Furcatum. Page 74.

* Chardstock; in a lane between Alston and Churchill.

Blackstalked Spleenwort. Asplenium Adiantum Nigrum.

Forked Blackstauked Spleenwort. Aspl. Adiant. Nig. Furcatum. Page 75.

* Musbury ; in the turnpike road to Axminster.

Variegated Blackstalked Spleenwort. Aspl. Adiant. Nig. Variegatum.

Kilmington; between the village and Shute lodge, also between the Honiton turnpike road and Marshes.

Southleigh; between Hangman's stone and Southleigh village.

Sea Spleenwort. Asplenium Marinum.

$$
\text { Page 44. }
$$

* Axmouth ; Charlton Bay.

Beer; on the rocks below the cliffs.

Wall Roe Spleenwort. Asplenium Rata Muraria. Page 47.

Lyme; rocks at Ware Cliff.

* Seaton; Beer cliffs. 
The two preceding places are mentioned as being nature's own habitat, but they are now more frequently found growing on artificial structures, as walls, bridges, \&c.

\section{Scaly Spleenwort. Ceterach Officinalis.}

\section{Page 49.}

Chaffcombe ; walls near Avishays.

Chard ; common on old walls.

Chardstock; Fordwater bridge and Wooden farm.

Churchstanton; on the churchyard wall.

Colyton; on a wall in the road to Seaton.

Combe St. Nicholas ; !

Crewkerne;

$\int^{\prime}$ on old walls.

Membury; Challenger, and on a ruined house near tho church.

Offwell; Wilmington.

Stockland; on a wall near Ridge.

Uplyme; the churchyard wall.

Wambrook; Farm-house garden wall.

HaRT's Tongue. Scolopendrium Vulgare.

Much-cleft Hart's Tonate. Scol. Vulg. Polyschides. Page 75.

Hawkchurch; between the village and Broom.

Lobed Hart's Tonate. Scol. Vulg. Lobatum.

Page 76.

Axminster; Secktor and Weycroft.

* Chaffcombe; between Avishays and the village.

Chard; road to Chardstock and near Cuttyford's door.

* Chardstock; not uncommon.

* Hawkchurch ; near the village and at Blackwater.

Mosterton; lane near the church on the opposite side.

Musbury; hedge-banks near the church.

North Perrott; hedge-banks near the mill.

Stockland; Cor-mill. 
Finger Hart's Tongue. Scol. Vuig. Multifidum. Page 76.

Axminster ; Secktor.

Hawkchurch ; Blackwater lane.

Monkton Wylde.

Branched Hart's Tongue. Scol. Vulq. Ramosum. Page 77.

Hawkchurch ; Blackwater lane. Monkton Wylde.

Simply Branched Hart's Tongue. Scol. Vulg. Simpliciter Ramosum. Page 77.

Chard ; road to Chardstock. Hawkchurch; in Berry lane.

Monkton Wylde; on the western side.

Northern Hard Fern: Blechnum.

Forked HARd Fern. Blechnum Furcatum.

Page 78.

Axmouth; Bog in Bulmore near Combpyne hill.

* Hawkchurch; near the village.

IT may be further remarked, that if the region of the Axe and its Tributaries be divided into districts, and to the five towns first mentioned an area of three miles all round be assigned,

1. Axminster has 19 species, all except the Sea Spleenwort, (Asplenium MLarinum.) Kilmington is included here.

2. Charmouth has the same. Monkton Wylde belongs to this district.

3. Chard has 17, not the Moonwort (Botrychium Lunaria) the Hay-scented Fern (Lastrea Fenisecii) or the Sea 
Spleenwort. Whatever portion of Chaffeombe is not within the area of three miles, must be considered as part of the Chard division.

4. Lyme has 19, for the Moonwort has not been discovered. Axmouth and Combpyne parishes must be considered as part of this group.

5. Colyton has 17, not the Moonwort, the Hay-scented Fern, or the Spinous Fern, (Lastrea Spinulosa.) The pleasant watering place Seaton, together with Beer and Musbury are to be included in this division.

6. Crewkerne, with the adjoining parishes in the region of the Axe, to the extent of five miles has 15, not the Moonwort, the Royal Flowering Fern (Osmunda Regalis) the Hay-scented Fern, the Spinous Fern, or the Sea Spleenwort.

If we take some of the other parishes and form them into groups,

7. Farway, Northleigh, Offwell, Shute, Southleigh, and Widworthy, have 19, not the Sea Spleenwort. Wiscombe Park in this district is a peculiarly favourable locality.

8. Chardstock, Cotleigh, Dalwood, Membury, and Stockland have 18. Moonwort and the Sea Spleenwort have not been discovered.

9. Buckland, Churchstanton, Combe St. Nicholas, Otterford, Wambrook, Whitestanton, and Yarcombe have 16. Moonwort, the Hay-scented and Spinous Ferns, and the Sea Spleenwort have not been found.

10. Cricket, Hawkchurch, 'Thorncombe, Wayford, and Winsham have 17, not the Spinous Fern, or Sealy Spleenwort, or the Sea Spleenwort. Hawkchurch is the most richly supplied of this group.

Note. The localities of Uplyme are in the district of Axminster, Charmouth, and Lyme respectively. 


\section{FOSSIL FERNS.}

All the observations hitherto made, have been on the Ferns found in our own district on the crust of the earth's surface. It will now be attempted to penetrate the recesses of the earth, and learn how plants, which once grew above ground, have been discorered, not green and fresh, but turned into stone, or as is commonly denominated, fossilized. Not only have shells and bones, and such hard substances been preserved, which existed some thousand years ago, but also vegetable productions, and especially Ferns. In Lyme and Charmouth, and the railway cuttings of the Exeter Extension Line, (all within our own neighbourhood) many animal remains have been found. In other parts of England very many fossil plants are met with of altogether a different species from those which now grow among us. In one of the editions of Withering's Botany, it is stated that the Royal Flowering Fern "is the only species of an indigenous vegetable ever discovered in a fossil state." This is not true. The Fern to which, probably, Withering alluded is Neuropteris Gigantea, once called Osmunda Gigantea, a plant of much more gigantic dimensions, and differing in many respects from our Osmunda Regalis.

Fossilized Ferns are found in various strata, in the Oolite, the New Red Sandstone, and the Slate, but in none do they so much abound as in the Coal. The Coal is made up of plants. None can stand near a coal mine and watch the blue shale brought up without finding it full of vegetable productions. The coal itself bears witness to the quantity of plants within it. "Myriads of plants are found in the coal, above the coal, and under the coal."* Of these vegetable remains in the coal flora one half are Ferns. There are throughout the world two thousand species of living Ferns. In the British Isles there are between forty and

* Lecture on coal by J. W. Salter. 
fifty: in the region of the Axe twenty. In the carboniferous formation two hundred have been collected, and in our British coal strata one hundred and twenty. It has been several times mentioned what a softness and elegance is given to the scenery by the various Ferns which adorn our heath fields, hedge-banks and woods. In like manner the Fossil Ferns, from their beautiful structure and neatly divided foliage, are the most remarkable and attractive vegetable remains in the ancient strata. Dr. Buckland in his Bridgewater Treatise observes "The finest example I have ever witnessed is that of the coal mines of Bohemia. The most elaborate imitations of living foliage upon the painted ceilings of Italian palaces bear no comparison with the beauteous profusion of extinct vegetable forms, with which the galleries of those instructive coal mines are overhung. The roof is covered as with a canopy of gorgeous tapestry, enriched with festoons of most graceful foliage, flung in wild irregular profusion over every portion of its surface. The effect is heightened by the contrast of the coal black colour of these vegetables with the light groundwork of the rock to which they are attached. The spectator feels himself transported, as if by enchantment, into the forests of another world; he beholds trees of forms and characters now unknown upon the face of the earth, presented to his senses almost in the vigour and beauty of their primeval life; their scaly stems and bending branches, with their delicate apparatus of foliage are all spread forth before him, little impaired by the lapse of countless ages, and bearing faithful records of extinct systems of vegetation which began and terminated in times of which these relics are the infallible historians."

In classifying living Ferns, the position of the fruit, the absence or presence of the elastic ring to the bags of spores, and of the covers to the masses of fruit; the shape, attachment, and situation of these covers are the groundwork on which the genera and suborders are founded. As the Fossil Ferns are for the most part destitute of fructification, it is impossible to adopt the same method of classification. To obviate this great difficulty, M. Adolphe Brogniart introduced a system, which is now constantly followed, of taking the form of the leaflets, and the direction and character of 
the reins, as the basis of his genera. By way of illustration, we will give a description of a few of these.

\section{Embrotdered Fern.-Pecopteris.}

The frond is once, twice, or thrice pinnate: the leaflets have a broad attachment as those of the Brake, Pl. II. fig. 19, and rarely have a stalk. The midrib reaches the tip of the leaflets and the veins are once or twice forked, and nearly at right angles to the midrib. In some species of this genus, clusters of fruit are found on the back of the frond. One of these Embroidered Ferns resembles Brake, another the Lady Fern, and another the Shield Fern, (Lastrea.) Many were undoubtedly Tree Ferns, and attained a large size. Some leaves four feet wide, and of a proportionate length, have been observed. This genus comprises a large proportion of the Coal Ferns.

\section{Nerved Leaf Ferk.-Neuropteris.}

This Fern has its frond divided, as the preceding. The midrib of the leaflets does not reach the tip, but branches off right and left into veins, and gradually disappears. The veins are very fine, curved, rising obliquely from the midrib. The leares egg-shaped or lance-shaped, somewhat heart-shaped at the base. "Clusters of fruit lance-shaped with a cover arising from the veins of the apex of the leaflets."-Richardson. One species resembles the Royal Flowering Fern, but differs in essential characters. Fruit rarely found, but when found, on the under side of the leaflet.

\section{Wedge-Leaf Fern.-Sphenopteris.}

The frond has its leaflets once or twice pinnatifid, wedgeshaped or narrowed at the base. The lower lobes of the leaflets are the largest. The leaflets are palmated, $i$. e. divided as the palm of the hand is into fingers. The veins radiate from the base. The Ferns of this genus are exceedingly elegant. In the bituminous shale at Edinburgh, some specimens of one species (Sphenopteris Affinis) are so perfectly preserved, as to admit of portions of the plant being taken up entire and pasted on paper like a recent Fern. The species amount to about thirty-six. 


\section{Tootin-Leaf Fern.-Odontopteris.}

Pinnæ pinnatifid. The leaflets are very thin, and adhere to the rachis of the pinnæ by their whole base. Mid-rib of leaflet absent or rudimentary. Veins equal, simple, or forked, mostly springing side by side from the base of the leaflet passing onwards towards the point. "In their general aspect, these plants resemble some South American species of Osmunda. Five species only are known, all of which belong to the most ancient coal strata."*

Four genera of Fossil Ferns have now been mentioned, that the nature of their classification may be understood. It is apparent that the form of the leaflets, and their attachment, and the distribution of their reins is the basis of the system. Whoever examines the British Ferns cannot fail to notice that in the leaflets there is generally a mid-vein of nearly equal thickness throughout, and that from that mid-vein side-veins issue right and left, which are sometimes simple, sometimes forked. Exactly the same is the case with the Fossil Ferns. In the Moonwort, (Botrychium Lunaria) there is no mid-vein, but the veins radiate from the base. (See plate III.) To these correspond the Wedgeleaf Fossil Ferns (Sphenopterides.)

With regard to fructification, it has been observed that in a large number of Fossil Ferns none has been discovered. In the Embroidered Ferns (Pecopterides) fronds having clusters of them are not uncommon. These clusters are on the back of the leaflets in rows on each side the mid-rein, in accordance with what occurs in the Shield Ferns (Lastrece.) A species also of the Wedge-leaf Fossil Ferns, (Sphenopteris Nephrocarpa) has been brought from the oolitic deposits of Scarborough, which has at the tip of the lobes of the leaves a kidney-form cover resembling the covers of the Male Fern (Filix mas.) The Nerved-leaf Ferns, (Neuropterides) have lance-shaped clusters, and thus in some manner resemble the Spleenworts. In the Royal Flowering Fern, not only is the fruit at the summit of the frond, but often at the ends of the pinnæ or branches, so

* Mantell's Medals of Creation. 
also in the Fern discovered in the old red sandstone in Ireland, Adiantites Hibernicus, the lower pinnæ have their highest ends covered with clusters of fruit. Such a similarity is there between the fruit found on living Ferns and the Ferns discovered embedded in coal or stone.

Another great distinguishing feature of the Fern tribe is their circinate vegetation, the curling-in of their buds. In almost every shady hedge-bank and wood, nay, on our old neglected castle walls and bridges, we behold some vegetable ammonite or shepherd's crook in the Ferns as they begin to bud. What we see so commonly in the spring months clothed in a garment of green, as delineated in the woodcut $\mathrm{b}$, page 5 , is also to be seen in a sable garment in some of our coal fields. In the museum in Jermyn street, London, there is a grand specimen with the delicate coil of pinnæ, every leaflet in its place, from the Le Botwood coal field. Let us, then, when we light our fire of a winter day, be on the look out and see whether we can discover the rolled-in bud of some Fern that grew in the British Isles in olden times.

There is one more distinctive mark by which these peculiar fossil plants may be discovered. If any should feel disposed to visit the other end of Somersetshire and inspect the coal mines on the Mendip hills, he may chance to fall in with some cylindrical blocks as black as jet. Not a single branch or leaf will be found remaining. A mis-shapen ugly stump.

"Monstrum, horrendum, informe, ingens." - Virg.

A horrid, hideous, great monster.

These stumps or blocks have many eyes, not taken out as that of the Cyclops of old, who lost the only eye he possessed. It so happens that they are marked with scars of considerable size. Such appearances are owing to the manner in which the fronds were broken off. Of this we have a picture in miniature in the creeping root-stock of the Polypody, as noticed in page 19. These great stems or trunks are called Caulopteris, Fern stem. They are short, round, or compressed. The scars are oblong, and much wider than the spaces between them. These are considered to have been part of the trunk of the Tree Ferns, and most probably some of the large fronds belonged to these trunks, 
but, as they are never found united, it is impossible to identify them. Not all these trunks belong to the Tree Ferns, indeed, the greater part do not. Many of them are called Sigillaria, which it is not our province to describe. Very few specimens of the Tree Fern stems are found in the British coal beds. Still there is no doubt whatever that there were once Tree Ferns in this our island, and that traces of them are to be found in our coal mines.

At first it might seem difficult to distinguish between the stems or trunks of other trees and those of the Tree Ferns. The scientific botanist has certain data, by which he can discern the difference in various plants. If he were taken to the tropics where such trees grow, and were shown a cylindrical block without a vestige of frond, or leaf, or fructification, his science would help him to ascertain to what kind of tree it belongs. It is well known that if a cross section be made of the trunks of the trees growing among us, a number of circles arising from a common centre are visible in the wood. This is especially apparent in fir-wood or deal. Such trunks have also a covering of bark. These trees are said to be exogenous, growing outward. Such are all the European trees. If the wood appears disposed irregularly in spots, and consists of tubes placed parallel to one another without the least appearance of these circles, and not the least trace of bark, then it is an endogenous plant, growing inward. Such are the palm trees and the canes, all our flags, lilies, and grasses. If the cross-cut of wood should show a sort of zig-zag formation, and unconnected layers with segments of circles having their ends outwards, or with something like an oak tree, or such odd appearances as is seen in the woodcut $\mathrm{g}$, page 61 , then it may be inferred that such is an acrogen, and most probably belongs to some Tree Fern. The scars occasioned by the breaking off of the fronds, as already alluded to, are another proof of the character of plant to which it belongs. Thus we see how we may discover the various classes of wood, not only in the now existing vegetable world, but even when the cylindrical trunk is compressed into a flat thin layer of coal. In some cases the distinctions mentioned may not be sufficient. To remedy this defect, other rules for the investigation of the character of stems are giren, which are too minute to 
be entered on in this work. Suffice it to say that our great botanists consider the structure and character of the trunks of the Fern Trees growing in the tropics and south temperate zone to correspond with what is found in a fossilized state in our coal measures.

A difficulty has arisen iu the minds of some as to the possibility of Fern Trees growing in our temperate zone. It has therefore been argued that the Ferns in our mines have been drifted from a considerable distance. Professor Lindley considers this not to be a correct view. He asserts that they grew, at the most, within a few hundred miles of the places where they are now deposited, and probably in their very vicinity. As a confirmation to his argument, he states that the vegetable impressions in the English coal measures were by no means water worn, while those in the British Museum, from Melville Island, were so rubbed and damaged, that they might have travelled from the very equator before they were deposited. This seems to clearly show that these plants grew near the spots where they are now found. Tree Ferns are now growing in New Zealand, and especially on the south side of Van Diemen's Land, where the mean temperature does not exceed 54 degrees Fahrenheit. The remains then of these plants is no good evidence of a tropical climate, or of a climate materially unlike that which we now experience.

Another question arises, how it comes to pass that the Ferns form so large a proportion of the plants found in our coal measures. Was not vegetation different in the days of their existence from that of the present time? How is it that there is not a trace found of the grasses and the numerous herbs and shrubs which now adorn our earth? Beautiful as the Ferns are, we love to see our "valleys stand so thick with corn, that they shall laugh and sing." Was there no corn in those primeval ages? Here again Professor Lindley has come to the rescue. On the 21st of March, 1833 , he filled a large iron tank with water, and immersed in it one hundred and seventy seven specimens of various plants belonging to the more remarkable natural orders, taking care to include representatives of those which are found in the coal measures, and those which are found generally dispersed over the globe at the present day, and 
might have been expected to exist in early times. On the 22nd of April, 1835, one hundred and twenty-one species had entirely disappeared; the fifty-six which remained were those which have their prototypes in the coal measures. The same experiment accounts for the want of fructification in Fossil Ferns, for it showed that one of the consequences of long immersion in water is a destruction of the fructification of those plants. The fact is, that Ferns have an antiseptic property - have a power of resisting the action of water. It is said that when M. Dumont D'Urville was shipwrecked, his plants sunk under water at the same time. When they were afterwards recovered, it was observed that the Grasses and Ferns were saved, while the exogenous plants were destroyed. Hence it seems most probable with respect to the coal formations, that all the plants first floated in the vater; that a certain portion of them, the Ferns, \&c., did not decompose, and that these were finally embedded in the rocks in which they are found. The coal shale with which they are surrounded, seems to have been originally mud, and thus is confirmatory of this opinion. It cannot therefore be concluded, because many plants now existing are not to be found in the coal measures, that therefore none such grew in the primeval days. Vegetation may have been as luxuriant and vigorous then as at the present day. It has been remarked that in Lindley's experiment, all the Horsetails, (Equiseta) were decomposed, though such are found in great abundance in a fossilized state. As these were the only exceptions, and as they may have been imperfect specimens on which he made the experiment, this is not sufficient to shake Lindley's hypothesis. The old proverb, "the exception proves the rule," may apply in this case as in a variety of others.

Whether the Fossil Ferns are a distinct species from those now existing, or whether they are varieties produced by altered circumstances, is a question too complicated to be discussed in such a work as this. The mignionette is a large perennial plant in its own native habitat; here it is a tender annual. When Britain was full of dense forests, with swamps in rich productive soil, the Fern Tree may have thrived in the inmost jungle, as it does now in New Zealand and Van Diemen's Land. It can hardly be imagined 
that such a noble tree bas dwindled into the more humble Ferns that grow among us, and therefore we must presume that it is extinct, at all events, in this portion of the globe. If ever our country should be a perfect swamp again, and our richly cultivated meadows be converted into a thick impervious wood, and our fruitful fields become a wilderness, then may these gigantic plants rear their heads once more, and their curious trunks full of deep scars from their fallen fronds appear.

It is wonderful when we learn how these subterranean plants have been so well preserved. "Some Ferns, nay many of them, remind us of the Tree Ferns familiar to our hot houses. Others resemble the humble fern-fronds of our lanes and hedge-rows. But all are perfect. It is rare to find a disturbed or crumpled leaf, though of course they are often only fragments, such as our brooks and rivers float down."* This is the more surprising, because those who wish to preserve specimens of Fern in a herbarium, have great difficulty in laying out the leaflets without their being sadly disarranged. Here again we may fairly infer that the water spread the foliage so nicely, and then it sank into the mud, where it hardened, and, after lengthened ages, now exhibits its fronds in such perfection. Though the rich glossy green is gone, the brightly polished black coal still tells a tale of its once elegant drooping frond, its neatly divided leaflets, its clear transparent veins, and buds bent-in like a bishop's crosier or a shepherd's crook.

It may strike some as deserving notice, that there were nearly three times the number of Ferns growing on British ground in those olden days. It is not easy to determine whether there were not many more than those we have at present in the time when Cæsar invaded Britain, and good king Alfred established such salutary institutions. There were no books of Ferns then, no amateurs searching our woods and walls to discover some new plant or variety, to find out the exact number, though the necromancers may have used the Fern-seed to make themselves invisible. If there were a greater number existing at that time, much more may we presume that in remoter days still these plants existed in yet greater abundance. One thing is certain,

* Salter's Lectures on Coal. 
that cultivation lessens the number of these wild plants, and introduces into its place trees, and fruits, and shrubs, which though not equally ornamental, are better adapted to supply the wants, and add to the luxuries of a rich and crowded population.

It may truly be said in conclusion, that these relics of vegetable organism are proofs of a great Creator's skill. Instead of leading us to doubt the truth of Scripture, these fossils silently and eloquently speak our Maker's praise. The divine may indeed preach a sermon on stones. The botanist here beholds every portion of a Fern in the stone. He has the root-stock, the stalk, the frond, the leaflet, the vein simple or forked, the fruit on the back or on the summit of the frond, and the curled-in bud. The antiquarian, when he has found a precious coin, of which the inscription is almost illegible, and the figure of the sovereign who issued it nearly effaced, can by certain rules of art determine the period when it was struck. In like manner, the Christian geologist beholds in the depths of the earth evidences, which though hard to decipher, certainly prove His power, who by His word made the heavens and the earth, and all things that are therein. There may be some difficulty at first in reconciling revelation with geological discoveries, and where are there not difficulties? Finite man cannot grasp all truth. It will, however, we rest assured, be ascertained in the result, that Biblical truth and natural science will harmonize, and that there will not be a shadow of difference between the creation as narrated by Moses and other inspired writers, and as unfolded by the various discoveries in the bowels of the earth. 


\section{THE FLOWER OF THE AXE.}

IN describing the Flower of the Axe, we speak not of the blushing rose, nor the pale scented violet, nor the yellow cowslip, which, while it forsakes the greatest part of Devon. shire, still thrives in our lovely vale. We speak of a flower of a blue colour and an acrid taste, so rare, so peculiar to a certain portion of this locality, that not all England can produce its like again. Neither has it ever yet received an English name. Its scientific designation is Lobelia urens. The inhabitants call it "The Flower." If a stranger bota* nist be observed rambling abroad and gathering wild flowers at some little distance from the favoured spot where this child of nature has cradled itself, the natives will exclaim :"You are in the wrong direction, sir, The Flower does not grow there." After searching and searching a little farther, perhaps he finds the plant, and, if not, after bestowing a trifling douceur, the peasant directs him to a place where he may gather a few stray specimens, so choice, so prized, because so rare. It belongs to the natural order Campanulacex and the tribe Lobeliex. The tribe Lobeliex differs from Campanuleæ (the other tribe of the Campanulacex) in having the flower irregularly divided, and the anthers united. The Campanulaceæ have the flowers more or less bell-shaped, divided into five lobes, and inserted on the calyx. The Lobelieæ are principally found in the warmer parts of the world. Only two of this tribe are found in England. Even in Europe few of these plants grow. In the hotter countries of South America, the Cape of Good Hope, and in the North of India, they are seen in great luxuriance. They abound in a milky juice, which in all is acrid, and in some cases produces dangerous, or even fatal consequences, when applied to the surface of the body, or taken internally. 


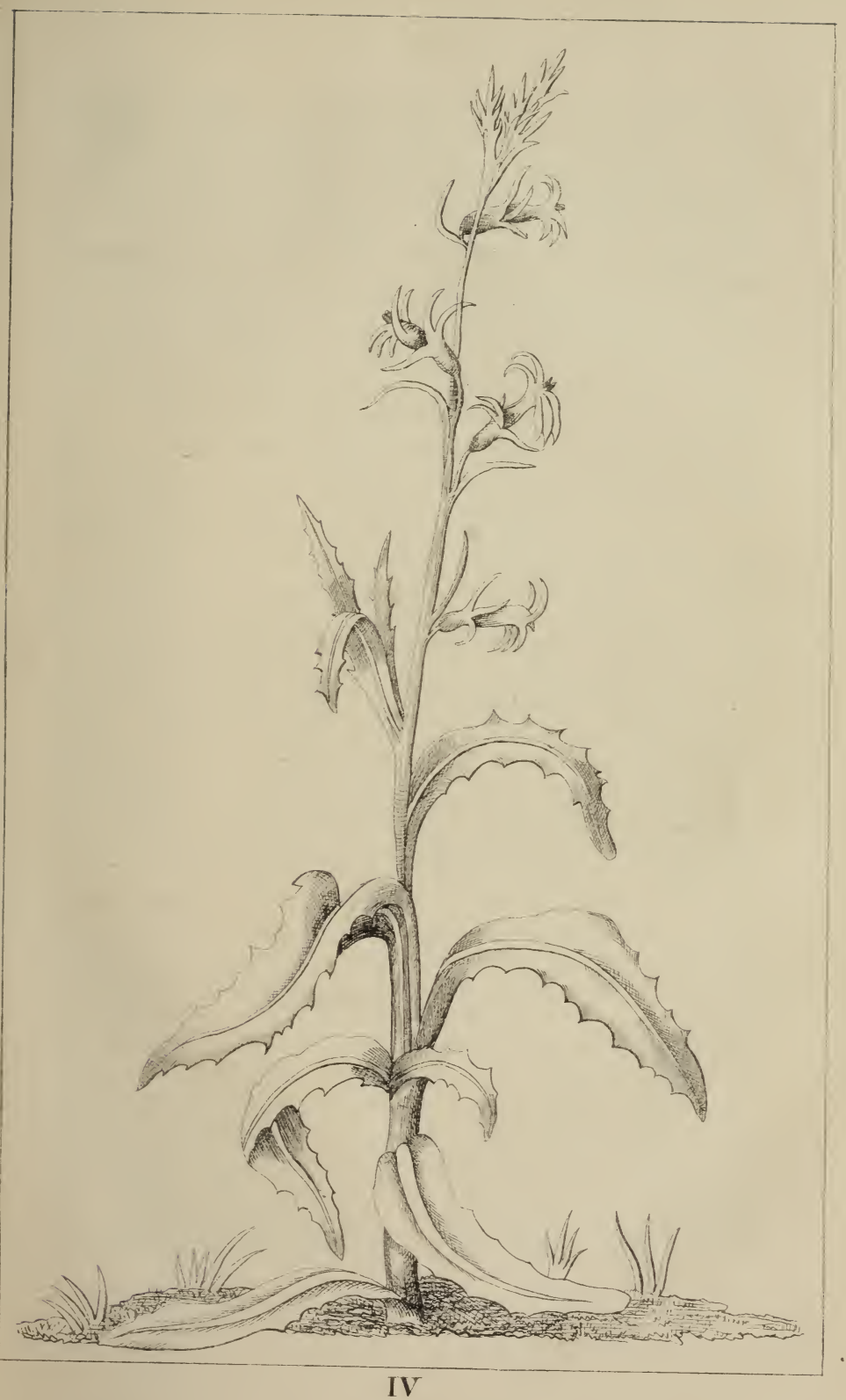



Lobelia Inflata, or Indian tobacco, is one of this tribe. This plant is of a medicinal character, and has been found useful in cases of asthma and hooping cough, but it is very different from the kinds of tobacco, Nicotiana, which are generally used for smoking. Little did Sir Walter Raleigh imagine when he first amused himself with smoking, and when his frightened servant threw a basin of water in his master's face, because he feared the fire would consume himlittle did the baronet imagine that in the course of three hundred years the pipe and cigar would be in the hands of the humblest peasant, as well as the proudest peer of the land. Lobelia urens, the plant of the vicinity of Axminster, has not only acrid leaves-leaves which would sting and blister the tongues of those who chew it-but it has also this character more especially exhibited in its roots. The history of this plant is rather interesting.

In the reign of Charles II. Dr. How made the first attempt to give a complete list of British plants. In the year 1650 , he published his Phytologia, which contained a description of twelve hundred and twenty. In this work our Lobelia is not noticed. The next catalogue of British Plants was made by Ray, one of the greatest English botanists. He first proposed what is called the natural system, and great as this discovery was, it is to be lamented that he obstinately continued in the old plan of separating trees from herbs. In the year 1660 , he published a catalogue of the plants growing in the neighbourhood of Cambridge, which he says took him ten years to complete. This is a most valuable work, developing his great mind. It is curious how he complains of wanting a guide to direct him in determining species. In 1670, he published a catalogue of English Plants, arranged alphabetically, and in 1677, a second edition. In 1690, he published a new edition, which he entitled, "A Methodical Synopsis of British Plants," and which he arranged according to his natural system. In 1696, another edition came out, and in 1724, it was republished by Dillenius. The edition published in 1696, is considered most accurate, and has been made the basis of all our Floras. Ray examined every plant with the greatest care, and his works remain a monument of his profound research and great intelligence. In neither edition of his 
Catalogue, * or of his Synopsis a ${ }^{\text {o }}$ British Plants, is our Flower mentioned. Neither did any other botanist speak of it as growing in England until the time of Hudson. Hudson does not allude to it in his first edition, published in 1762 . In 1778, a second edition was issued, in which a description was given in Latin, of which the following is a translation.-

\section{Toxr. II. Page 377. "LOBELIA."}

"Calyx five-cleft. Corolla monopetalous (consisting of a single petal) irregular. Capsule inferior of two or three cells."

"1. Lobelia Dortmanna."

\section{Page 378.}

“2. Lobelia Urens. A Lobelia with a stalk nearly erect; with the lowermost leaves somewhat round, notched, with the upper lance-shaped serrated, with the flowers in clusters."

Hudson next mentions that it was noticed as growing in France by Morison, in his Universal History of Plants, published at Oxford, in three parts, with large folio plates, ${ }^{b}$ in the year 1680. He quotes the words of Morison, part II, page 467 , which were also written in Latin.

"A Rapunculus with a vaulted corolla growing at Blois or Sologne in France, with a smaller blue flower."

He next quotes from another book of Morison, and from books of three other authors besides, in which it is designated "The stinging Rapuntium of Sologne." $\dagger$ viz:-Morison's Royal Garden of Blois." Paul Boccone's Drawings and Descriptions of the rarer plants of Sicily, Malta, France, and Italy. $\ddagger$ Ray's History of Plants, page 746. Monnier's

* Catalogus plantarum Angliæ, A.D. 1670, and 1677. a Synopsis Methodica Stirpium Britannicarum, A.D. 1690, 1696, and 1724. B A friend has seen the plate containing the root, stem, and flower of Lobelia Urens, as published in this old book, in tho British Museum, and pronounces it a perfect counterpart of the plant which grows at Kilmington. c The garden attached to the Castle at Blois was planted by Henry IV. IIorison, an Englishman, having followed the disastrous fortunes of Charles I. published a Catalogue of the plants of this garden, which had acquired considerable celebrity. Its title was, Hortus Regius Blesensius, or Hortus R. Blesensis. Londin. 1669. Fie afterwards published the work first quoted by Hudson, The Universal History of Plants.

+ Sologne is a parish of Blois. Its church is the largest in the town, and was rebuilt by Louis XIV. who converted it into a Cathedral.

$\ddagger$ For an account of Paul Boccone, Caspar Bauhin, and Monnier, see p. 114 \& 115. 
Observations made on Natural History in the Southern Provinces of France, in the year 1739, page 131.

Lastly he brings forward a passage from Caspar Bauhin's work, published at Basle, in Switzerland, in the year 1674, in which it is described as "A draba with a blue flower, having a vaulted corolla."

Hudson concludes his account thus, -

"In English stinging. Habitat in mountainous meadows. A bove Shute hill, between Axminster and Honiton. Mr. Newbery."*

Thus it appears that the flower was mentioned before the time of Ray, and by Ray himself as being found wild near Blois, in France, or as it is otherwise described, in the fields of Sologne. Indeed, in Morison's work, it is said to grow there "in all directions in moist heath-fields and old woods, and also in other parts of France towards Poitiers." $\uparrow$ "'Ihe whole plant" he remarked, "is very hot, especially its root; when chewed, it pricks and stings the tongue. It is wrongly called by Caspar Bauhin, a Draba with a blue vaulted flower, for it has no similarity to a Draba, the species of which have a pouch or silicule." $\ddagger$

As Hudson first described it as an English plant in 1778, and quotes as his authority Mr. Newbery, it is probable that Mr. Newbery discovered it between 1762 and 1778 . At this time Mr. Newbery lived at Heathstock, in the parish of Stockland, and as he was a noted herbalist, and had the reputation of knowing every plant of the neighbourhood, was likely to notice the flower when journeying to Axminster. Polwhele says, $\S$ “The late Mr. Newbery was well known (particularly in Devonshire) as a botanist. Botany indeed was the only pursuit in which he was conspicuous." The same writer also remarks ${ }^{a}$ on the habitat

* Mr. Newbery's Christian name was William. D. before Newbery in the Latin text stands for Dominus, Mr.

† "Towards Poitiers" is taken from Morison's other work, Hist. Plant. Univers. where he gives a similar account of the Lobelia.

† Tota planta percalida est, præcipue ejus radix; masticata linguam urendo pungit. Crescit in humidis ericetis, passim inagro Soloniensi alibique in Gallia. Male a Casparo Bauh. in pin. pag. 110, collucatur pro draba flore cæruleo galateo, quum nihil habet affinitatis cum siliquosa draba, cujus draba est species.

Hortus Regius Blesensis, Auctus. Auctore Rob. Morison. Londini, 1669.

$\S$ History of Devon. I 81 n. A.D. 1797. a Ibid, p. 93. 
of the plant, "On high grouna's above Shute Common, between Axminster and Honiton. Mr. Newbery." There is a beautiful full length figure of the flower in Curtis's Fl. Londinensis, vol. 2, 183. Lord Webb Seymour, who sent it to Curtis in 1796, says it grows in a poor gravelly soil on the slupe of a heath, called Kilmington hill, from the parish in which it is situated, and about two miles from Axminster. It is there confined to one spot not exceeding half an acre, close to the road, and about fifty yards on the right harid side in going from Axninster to Honiton. He could not find it any where else after a careful search.

The earlier and correcter editions of Withering, (editions 2 and 3, A.D. 1787 and 1796) give that station, and on the same authority. Smith, (Fl. Britt.) gives Kilmington hill (on the authority of Curtis's Fl. Londin.) two miles from Axminster, close to the road. Smith adds in his later books, "Near Ottery St. Mary. Miss Burgess." Dr. Beeke, in his Botanist's Guide, tells us that "Kilmington hill and Shute Common are the same place, and that the plant is confined to a spot of ground about 200 yards in length." The above is all the information afforded. Mr. Ravenshaw, late Curate of Ilfracombe, who has recently published a "New List of the Flowering Plants and Ferns growing wild in the county of Devon," has fallen into the mistake of separating Shute Common from Kilmington hill, and has added two other localities, Seaton and Woodbury Common. With respect to Seaton it is too near home for the flower to have escaped observation, if it had been growing there. As to Woodbury Common, it seems that Mr. Ravenshaw drew his information from the Supplement to the New Botanist's Guide, in which the mistake was first made. In that work, Mr. Abraham of Heavitree, near Exeter, is quoted as the authority for that station, who, upon enquiry, has kindly communicated in reply that this is "an erroneous statement." It may be remarked with reference to the flower being found growing at Ottery St. Mary, that this was not correct. Miss Burgess of Ottery, was on a visit at Coryton House, ncar Axminster, when she observed it, and made others acquainted with the circumstance. Hence originated this mistake. No allusion has been made to a solitary plant's being found growing at Ashford, in Kent, 
in August, 1850. Though a singular circumstance, it is not sufficient to prove that this is another habitat. It may have been introduced into the neighbourhood by an amateur, or some bird may have brought the seed.

'The plant is very abundant throughout the Western part of France, and extends far into the interior, as near Paris. It also grows in the ricinity of Cherbourg, Caen, and other places near the Channel.* Nymant also states, that it is recorded as growing in Asturias, Gallicia, and Andalusia in Spain, and also in Portugal. $\ddagger$

Lecoq, $\$$ a French writer on the Botanical Geography of Europe, remarks that "Its range is rather limited. On the South it is in France and Spain. On the North it rises in France as far as the Isle of Manche, and reaches even to England. It is in the West" (of France) "and extends from England to the coast of Portugal."

"Limits of the extent of the Species."

"South. Spain $39^{\circ} \quad$ Distribution in latitude

"North. England $\left.51^{\circ}\right\} \quad 12^{\circ}$

"West. Portugal $\left.11^{\circ}\left(9^{\circ}\right)\right\}$ Distribution in longitude

"East. France $\left.0^{\circ}(2 \mathrm{E})\right\} \quad 11^{\circ}$

In Kilmington Common it has at present a range of about a mile in length, and in no place more than a hundred yards in breadth. In some fields that have been recently cultivated, within the range of its usual haunt, the flower has appeared in great abundance on the newly turned up ground. A more precise description of its exact locality will not be given, as some naturalists are of a very grasping character, and instead of taking a few specimens, a case has occurred, where a basketful has been burne away by a single individual. We should be sorry to have the plant exterminated, and we take this opportunity of warning our country friends not to give too great publicity to the subject. The angler does not disclose to every individual the spot where he would be likely to get most sport, and he would be particularly

* See the French Floras of Grenier and Godson, Lloyd and Brebissou.

+ Sylloge Floræ Europeæ.

¥ The Author is indebted to C. Cardale Babington, Esq., M.A., F.L.S., F.G.S. Professor of Botany in the University of Cambridge, for this information as to the foreign habitats of the Lobelia, and for many other interesting particulars.

$\S$ Lecoq, Etudes sur la Geographie Botanique de l'Europe, vol. 7, page 293. 
careful not to do so if he found a person of a greedy and poaching propensity. It was feared that cultivation would rob us of our jewel. This has not happened. Still the precious gem remains. Let us now so watch over the Flower of the Axe, that while we will show to the student of nature how it still exists, we will not give to the invading foe the opportunity of tearing it up root and branch.

Our Lobelia* very much resembles that which is found in gardens. The corolla or flower is divided into two parts or lips. The upper lip is again divided into two, and the lower lip into three parts. The colour is light blue. The stem is nearly upright. The lower leaves are inversely eggshaped or oblong, and slightly toothed. The upper leaves are lance-shaped and serrate. The flowers are in a loose cluster, and appear in the months of July, August, and the early part of September. Why this plant should have fixed on this particular spot, and be found wild in no other place in Scotland, England, or Wales, is indeed a mystery. Many plants are considered to be naturalized and only an escape from gardens. No botanist has ever doubted that this is a thoroughly wild plant, and that no cultivation was ever the the cause of its visiting these regions. There are many places in England, and in Devonshire, where the soil and climate seem to be precisely similar, and yet it has never been discovered in any of these places. There is no unvarying general rule for nature's productions.

With regard to the different species of the animal and vegetable tribes, it is sometimes extremely difficult to account for their locality. In the bleakest regions we occasionally meet with tropical plants, and in the torrid zone we light on fruits and flowers alone to be expected in our colder clime. There is, however, sufficient regularity to reward and to amuse the student of natural history.

\section{-Not a flower}

But shows some touch in freckle, streak, or stain

Of his unrivalled pencil. He inspires

Their balmy odours and imparts their hues, And bathes their eyes with nectar and includes In grains as countless as the sea-side sand The forms which sprinkle all the earth. 
Iappy who walks with him! Whom what he finds

Of flavour or of scent in fruit or flower,

Or what he views of beautiful or grand

In nature-from the broad majestic oak

To the green blade that twinkles in the sun-

Prompts with the resemblance of a present God.-Cowper.

Lobelia Urens, now found only in a small portion of our district, may in olden times have flourished in other places in the South of England. Even now its seeds may lie buried, and if the seeds should be moved up by the plough or by the spade, the plant may exhibit itself in some similar situation. Most extraordinary is the suspension of vegetable life. In ploughing an inch or two deeper than usual, the husbandman gives vitality to the wild mustard (commonly called charlock) whose seed may have been below the region of vegetation for many a year, and, behold, his field of corn is almost choked by the luxuriant yellow crop! Grains have been found in the Egyptian mummies where they had remained for 2000 years, and, wonderful to say, when sown in the ground have vegetated and come to perfect plants. The wild flowers, and ferns, and sedges of the bogs, die when the ground is thoroughly drained. Let the drains be choked, and the dry land become a marsh again, and then the rushes and carnation grass, and all the wet plants appear. How comes this to pass? Not because new seed is deposited, for all the ground around may be in excellent cultivation, and altogether destitute of any such plant. There has been a suspension of vegetable life in the buried seed, and when the soil is in a suitable condition, then does germination and fructification arise. It is not impossible that the fresh earth, cast up in working the railway, may add some fresh flower to the neighbourhood, and a vegetable that existed in the days of Canute may reappear in the Vale of the Axe.

It may be interesting to our classical readers if we furnish them with Hudson's description of our flower, as it was originally written in the Latin language. It will be observed that it is in accordance with the liberal translation with which we have furnished our readers. This is an exact copy taken from the work in the library of the British Museum. Gulielmi Hudsoni, R.S.S. et Pharm. Lond.

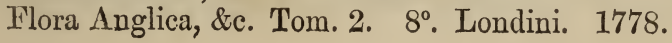


Præf. iii. Numeri I II III tempus florendi indicant viz. Jan. Feb. Mart. \&c.

Hanc occasionem lubens amplector gratias agendi amicis, qui mihi plantas pro eorum benerolentiâ suppeditarunt, inter quos nominandi sunt* Domini Alchorne \&c.

Tom. II. P. 377.

Lobelia.

Cal. quinquefidus. Cor. monopetala, irregularis.

1. Lobelia Dortmanna.

Caps. infera bis. trilocularis.

Page 378.

2. Lobelia urens. Lobelia caule erectiusculo, foliis inferioribus subrotundis crenatis, superioribus lanceolatis serratis, floribus racemosis. Sp. pl. (Species plantarum) 1321.

Rapunculus galeatus blesensis $\mathrm{s}$. soloniensis, flore violaceo minimo. (1) Hist. Ox. II 467 t. 5 f. 56.

Rapuntium urens soloniense. ${ }^{(2)}$ Hort. $\mathrm{R}$ bl. $300 .{ }^{(3)}$ Boce. sic. 20 t. $11 . \quad{ }^{(4)}$ R. Hist. 746.

Draba flore cæruleo galateo.

(5) Monn. obs. cxxxj.

(6) B. pin. 110. pr. 53

Anglis, stinking Lobelia. (Among the errata P. 378, for stinking, r. stinging.) Habitat in pratis montosis. Supra Shute common inter Axminster et Honiton. D. Newbery. VII. VIII.

Explanations of abbreviations as given by Hudson.

(3) Bocc. sic. Pauli Boccone Plantarum Rariorum Siciliæ Icones et Descriptiones. Oxon, 1674. 4to.

(6) B. pin. Caspari Bauhini Prodromus et Pinnax Theatri Botaniei. Basil, 1671. 4to.

Explanation of the other abbreviations.

(1) Plantarum Historia Universalis. Auctore Roberto Morison. Oxon, 1680. Pars. II. p. 467. t. 5. f. 56.

(2) Hortus Regius Blesensis. p. 300. Morison. A.D. 1669.

(4) Ray. Historia Plantarum. p. 746. A.D. 1686 or 1688.

(5) La Meridienne de l'Observatoire Royal de Paris. \&e. Par M. Cassini Thury de l'Académie Royal des Sciences. Arec des Observations d'Histoire Naturelle, faites dans les Provinces traversées par la Meridienne par M. le Monnier de la même Académie Docteur en Medecine. 4to. Paris. 1744.

* This sentence is inserted to show that D. Newbery, means Dominus, Mr. Newbery, and is not the Christian name, as already mentioned in page 115. 
A short account is subjoined of three botanists' eminent in their day, who have been alluded to by Hudson in his description of the Lobelia.

Boccone Paul Silvius. He was born of a noble family at Palermo in 1633, where he died in 1704. He published a small number of works, and has left others in manuscript. $\mathrm{He}$ had in his youth a passion for the study of natural history in general, and of botany in particular. He travelled through the different countries of Europe to satisfy this taste. In Paris he made the acquaintance of the Abbé Bourdelot. In 1674, he published at Amsterdam his "Researches and Observations on Natural History."* There are in this little work some very curious matters. Having connected himself while in London with Hatton, Sherard, and Morison, the last named induced him to publish a work on the plants which he had observed, and took charge of its revision and printing. This work appeared at Oxford under the title of "Drawings and Descriptions of the Rarer Plants of Sicily, Malta, France, and Italy," in 1674 4to. with 52 plates. He published afterwards at Venice by the advice of Sherard, another work more extensive, under the title, "A Museum of the Rare Plants of Sicily, \&c." $\ddagger$ Eight other works are named. He was appointed Botanist to the great Duke of Tuscany, but in 1682 became a monk under the name of Sylvius. $\S$

Bauhin, Gaspard. In Basle, famed for its learned University, was the subject of this article born and educated. After finishing his college education, he visited several parts of Europe that he might gain an insight into its vegetable productions, which in those days were so important a constituent of medicine. On his return to his native town, he was in high repute as a most learned man, and celebrated naturalist. The greatest honours were bestowed upon him, and he was appointed professor of Greek, of Anatomy, and Botany. Though he wrote several Medical Treatises, yet he is most distinguished for his Botanical publications. The work quoted by Hudson, which came from the press in 1623 and 1671, was a complete key to the knowledge

* Recherches et Obserrations d'Historie naturelle.

‡ Museo di plante rare della Sicilia, \&c. Venice, 1697.

$\S$ See Biographie Unirerselle. Paris, 1811. 
of the day. It was embellished with descriptions and figures of new plants, and with collections of the names given by the writers who preceded him. His zeal, learning, and good sense, aided by unwearied industry, contributed greatly to the advance of Botany, and was exceeded by none except Iinnæus in this department of the science. His book was for years considered a standard work, and was constantly resorted to by those who wished to become acquainted with the characters and habits of the various portions of the vegetable world. Forty years were devoted to the completion of this publication, and if we wish to ascertain the name given by any old writer to a plant, we have only to consult Gaspard Bauhin, and there it will be easily discovered. The chief blemish in his work is a want of order and arrangement. He seems to have been reproved by our countryman Morison, for placing the Lobelia under a wrong genus. He died at Basle in 1624.

Monnier, Louis William. This writer is less known than the others whose works are quoted by Hudson. It seems that Louis XV. was anxious to have a correct map of France. To accomplish this, M. Cassini de Thury made a trigonometrical survey of that kingdom, and in 1744, published an account of it under the title of "The Meridian of the Observatory of Paris, verified throughout the whole extent of the kingdom by new observations, \&c." The map was not finished by him, but by his son. That the publication might be more complete and more interesting, M. le Monnier, a celebrated physician and naturalist, inserted what is in fact an Appendix to the main treatise, "Observations on the Natural History of the Provinces in the Soush of France." He was a member of the Royal Academy, and made these observations in the year 1739. In the page which is marked cxxxj,* with small Roman numerals, he calls the Lobelia the stinging Rapuntium of Sologne, $\uparrow$ and quotes Morison's Roval Garden of Blois, as his authority for the name. "This plant" he remarks, "is common enough in all" (the province of) "Berry; its leaves are much larger and more

* There is another page in the book marked 131.

+ Rapuntium urens soloniense. Mor. H. R. Blaes. Cette plante est assez com. mune dans tout le Berry; ses feuilles sont beaucoup plus grandes et plus succulentes dans le Rendonnay que dans les pres humides de la Sologne; mais elle n'en pas pour cela moins brulante. 
succulent in Randonnay, than in the moist meadows of Sologne, but it is not on that account the less acrid." In 1738, he was attached to the Infirmary of St. Germaine-enlaye. Circumstances and his position developed his taste for Botany, and to this science he rendered great service. Called to the Court, he was appointed Professor of Botany. He was made chief Physician to the Royal Family, and latterly also to the King. Passionately fond as he was of studying nature's fair flowers, and shrubs, and trees, he had an additional impulse given to the natural bent of his mind by being employed in superintending the laying out of the lovely gardens of Trianon, and also the gardens of Elizabeth, sister of Louis XVI. at Montreuil, near Versailles. Various other works did this gifted man publish besides his "Observations on Natural History." He lived to behold the fearful Revolution, and the anarchy and bloodshed consequent thereon, and the untimely end of his patron Louis XVI. for he died in 1799 . 
The figures denote the page. $\mathrm{C}$ stands for common. $\mathrm{F}$ for fern or ferns. var. for Variety.

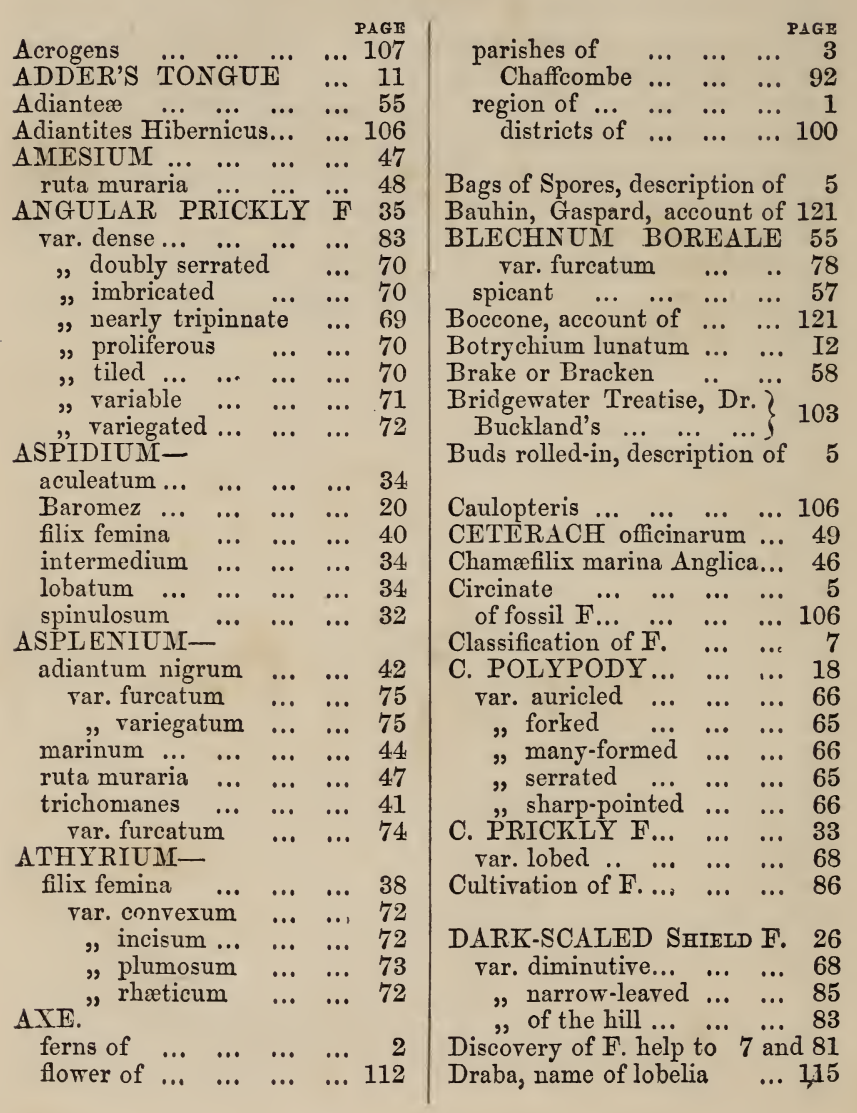


Dryopteris PAGE

Elastic ring, description of... 5

Embroidered F. ... ... ... 104

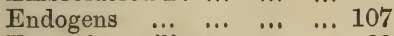

Eupteris aquilina... $\quad \ldots \quad \ldots 6 \quad 62$

Families of Polypods ... $\quad \ldots \quad 9$

Feathered shield F. ... $\quad \ldots . \quad 25$

Female F. of Theophrastus... 62

Flower of the Axe $\quad . . \quad \ldots \quad 112$

Flowering F. Royal ... $\ldots . \quad 15$

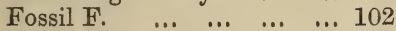

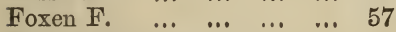

Frond, description of ... ... 7

Fructification of F. ... $\quad$... $\quad 7$

Genera of E... $\quad \ldots \quad \ldots \quad \ldots \quad$... fossil $F \ldots \quad \ldots \quad \ldots \quad \ldots 103$

Geographical distribution of F 7 of lobelia ... $\quad . . \quad \ldots . \quad \ldots \quad 117$

Geralde the Herbalist... ... 4

Gymuogramme $\quad . . \quad \ldots \quad \ldots \quad \ldots \quad 18$

Habitats of rarer F. ... ... 92

HART'S TONGUE ... $\ldots . .52$

$\begin{array}{llll}\text { var. branched ... } & \ldots & \ldots & 77\end{array}$

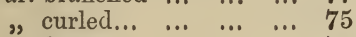

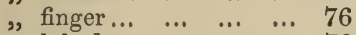

" lobed ... $\quad \ldots . \quad \ldots \quad \ldots \quad \ldots 6$

"much-cleft... $\quad \ldots \quad \ldots \quad 75$

"simply-branched ... 77

Hay-scented F. ...

Hybrids, how formed ... $\quad . . .87$

$\begin{array}{lllllll}\text { LADY } & \text { F. } & \ldots & \ldots & \ldots & \ldots & 38\end{array}$ $\begin{array}{lllll}\text { var. deep-cut } & \ldots & \ldots & \ldots & 72\end{array}$

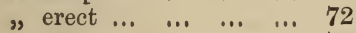

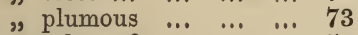

Langue de cerfe $\ldots . . . \quad \ldots . \quad 54$

LASTREA, description of ?

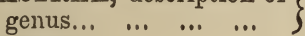

$\begin{array}{llllll}\text { æmula } & \ldots & \ldots & \ldots & \ldots & 30\end{array}$

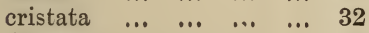

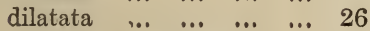

rar. angusti-pinnula $\ldots \quad 85$

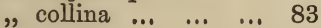

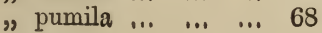

PAGE

$\begin{array}{llllll} & & & & & \\ \text { flix mas } & \ldots & \ldots & \ldots & \ldots & 23\end{array}$

$\begin{array}{lllll}\text { var, affinis } & \ldots & \ldots & \ldots & 66\end{array}$

„ Borreri ... ...

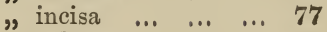

„, paleacea...

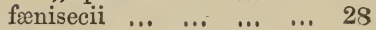

$\begin{array}{llllll}\text { montana } & \ldots & \ldots & \ldots & \ldots & 21\end{array}$

$\begin{array}{llllll}\text { recurva } & \ldots & \ldots & \ldots & \ldots & 30\end{array}$

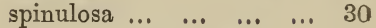

Lesser rough Spleenwort ... 57

Lindley, experiment of ... 108

LOBELIA URENS ... ... 112

Localities of the rarer F. ... 92

Lonchitis aspera minor $\quad . . \quad 57$

LOPHODIUM (defined) ... 25

$\begin{array}{llllll}\text { fænisecii } & \ldots & \ldots & \ldots & \ldots & 30\end{array}$

$\begin{array}{lllll}\text { multiflorum } & \ldots & \ldots & \ldots & 27\end{array}$

spinulosum $\quad \ldots \quad \ldots \quad \ldots \quad 32$

MAIDENHAIR SPLEEN- $\} 41$

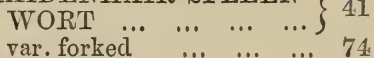

$\begin{array}{llllll}\text { MALE F. } & \ldots & \ldots & \ldots & \ldots & 23\end{array}$

$\begin{array}{lllll}\text { var. } \text { chaffy... } & \ldots & \ldots & \ldots & 67\end{array}$

$\begin{array}{lllll}\text {, deep-cut } \ldots & \ldots & \ldots & 66\end{array}$

$\begin{array}{lllll}\text { MOONNWORT } & \ldots & \ldots & \ldots & \\ \text { MON } & \ldots & 12\end{array}$

Monnier, account of $\ldots . . .122$

Monstrosity, definition of ... 80

Morison, account of ... ... 114

description of Lobelia by 114

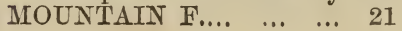

NEPHRODIUM

spinulosum-

var. æmulum... $\quad \ldots \quad \ldots \quad 30$

, bipinnatum ... $\quad . . . \quad 32$

$\begin{array}{lllll}\text { oreopteris ... } & \ldots & \ldots & \ldots & 23\end{array}$

Nerved leaf F. ... $\quad \ldots \quad \ldots \quad 104$

Neuropteris ... $\ldots . . . . \quad \ldots \quad 104$

NORTHERN HARD F... 55

Odontopteris $\quad \ldots \quad \ldots \quad \ldots 105$

$\left.\begin{array}{l}\text { OPHIOGLOSSUM VUL- } \\ \text { GATUM }\end{array}\right\} 11$ var. $\quad \ldots \quad \ldots \quad \ldots \quad \ldots 65$

OSMUNDA REGALIS ... 15

$\begin{array}{llllll}\text { spicant } & \ldots & \ldots & \ldots & \ldots & 57\end{array}$

$\begin{array}{llllll}\text { Ostrich F. } & \ldots & \ldots & \ldots & \ldots & 57\end{array}$ 
Pecopteris $\quad \ldots \quad \ldots \quad \ldots \quad \ldots \quad$ PAGE

Plumous lady F. ... $\quad \ldots \quad \ldots \quad 73$

POLYPODIUM VULGARE 18 $\begin{array}{lllll}\text { var. acutum } & \ldots & \ldots & \ldots & 65\end{array}$

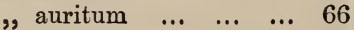

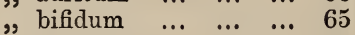

" multiforme... $\quad . . . \quad \ldots .66$

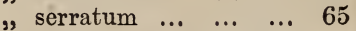

POLYPODY, (see Common Polypody)

$\left.\begin{array}{cccc}\text { POLYSTICHUM } & \text { ACU- } \\ \text { LEATUM } & \ldots & \ldots & \ldots\end{array}\right\} \quad 33$

$\begin{array}{lllll}\text { var. lobatum... } & \ldots & \ldots & 68\end{array}$

$\left.\begin{array}{ccccc}\text { POLYSTICHUM } & \text { ANGU- } \\ \text { LARE } & \ldots & \ldots & \ldots & \ldots\end{array}\right\} 35$

$\begin{array}{llll}\text { var. biserratum } & \ldots & \ldots & 70\end{array}$

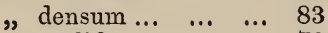

$\begin{array}{lllll} & \text { proliferum } & \ldots & \ldots & 70\end{array}$

" subtripinnatum ... 69

$\begin{array}{lllll} & \text { "variabile... } & \ldots & \ldots & 71\end{array}$

$\begin{array}{lllll} & \text { variegatum } & \ldots & \ldots & 72\end{array}$

Prickly F. Angular, (see Angular Prickly F.)

Prickly F. common, (see C. Prickly F.)

PTERIS AQUIIINA _.. 58

Ray, account of $\ldots \quad \ldots \quad$...

$\begin{array}{lllll}\text { Royal flowering F... } & \ldots & \ldots & \ldots & 15\end{array}$

Scaly Spleenwort... $\quad \ldots \quad$... 49
SCOLOPENDRIUM VUL-
GARE
PAE
52

$\begin{array}{lllll}\text { var. } \operatorname{crispum} . . . & \ldots & \ldots & \ldots & 75\end{array}$

$\begin{array}{lllll} & \text {, lobatum... } & \ldots & \ldots & 76\end{array}$

$\begin{array}{lllll} & \text { multifidum } & \ldots & \ldots & 76\end{array}$

„, polyschides $\ldots . . . .75$

", ramosum $\quad . . \quad \ldots \quad 77$

" simpliciter ramosum 77

$\begin{array}{lllll}\text { Sphenopteris... } & \ldots & \ldots & \ldots & 104\end{array}$

$\begin{array}{llllll}\text { spinous F. } & \ldots & \ldots & \ldots & \ldots & 30\end{array}$

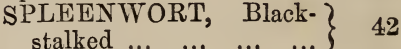
$\begin{array}{lllll}\text { var. forked } & \ldots & \ldots & \ldots & 75\end{array}$ $\begin{array}{lllll}\text { variegated } & \ldots & \ldots & 75\end{array}$

$\begin{array}{lllll}\text { Maidenhair } & \ldots & \ldots & \ldots & 41\end{array}$

$\begin{array}{lllll}\text { var. forked } & \ldots & \ldots & \ldots & 74\end{array}$

$\begin{array}{lllllll}\text { Sea } & \ldots & \ldots & \ldots & \ldots & \ldots & 44\end{array}$

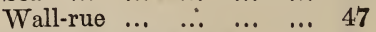

$\begin{array}{lllll}\text { STRUTHIOPTERIS... } & \ldots & 57\end{array}$

$\begin{array}{llll}\text { Sweet Mountain F. } & \ldots & \ldots & 21\end{array}$

$\begin{array}{lllll}\text { Tartarian lamb } & \ldots & \ldots & \ldots & 20\end{array}$

$\begin{array}{llllll}\text { Tooth-leaf F... } & \ldots & \ldots & \ldots & 105\end{array}$

$\begin{array}{llllll}\text { Tongueworts... } & \ldots & \ldots & \ldots & 8\end{array}$

$\begin{array}{llllll}\text { Tree F. ... } & \ldots & \ldots & \ldots & \ldots & 106\end{array}$

Varieties, definition of $\ldots 80$

$\begin{array}{lllllll}\text { Veins } & \ldots & \ldots & \ldots & \ldots & \ldots & 6\end{array}$

Wall-rue Spleenwort $\quad \ldots \quad \ldots \quad 47$

$\begin{array}{lllll}\text { Wedge-leaf } F . & \ldots & \ldots & \ldots & 104\end{array}$ 


E- $+$ 
